\title{
Litte Gardens
}



\section{Charles $\cdot$ Y.Skinner}
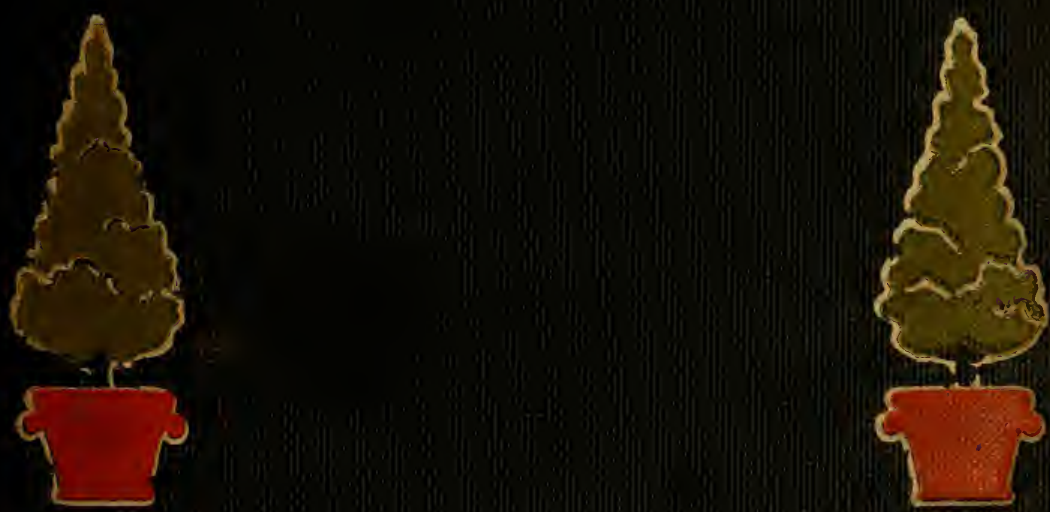


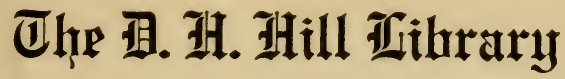

Ãarth Carnlina State

\section{Uallpgp}

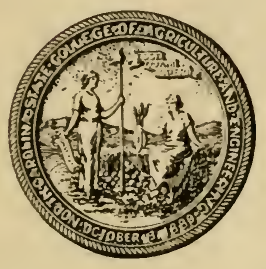

This book was presented by Alfred B. Yeomans

SB455 $\mathrm{S} 7$ 


\section{0}

This book may be kept out TWO WEEKS ONLY, and is subject to a fine of FIVE CENTS a day thereafter. It is due on the day indicated below:

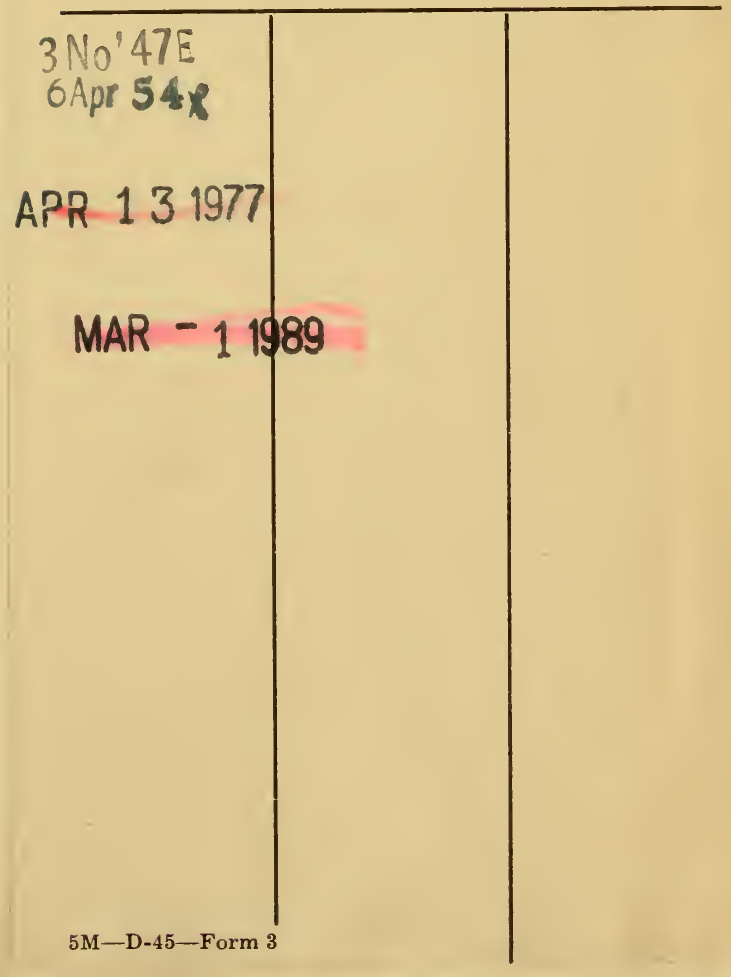





\section{LITTLE GARDENS}






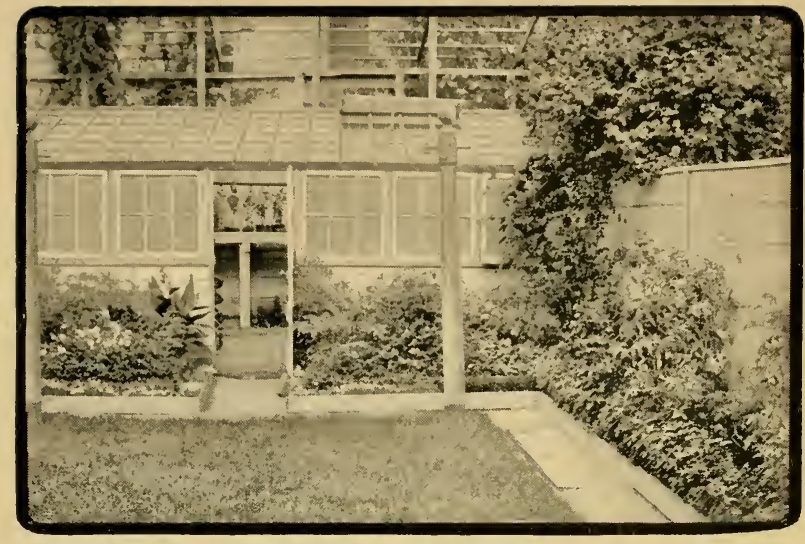

A CI'TY BACK YARD.

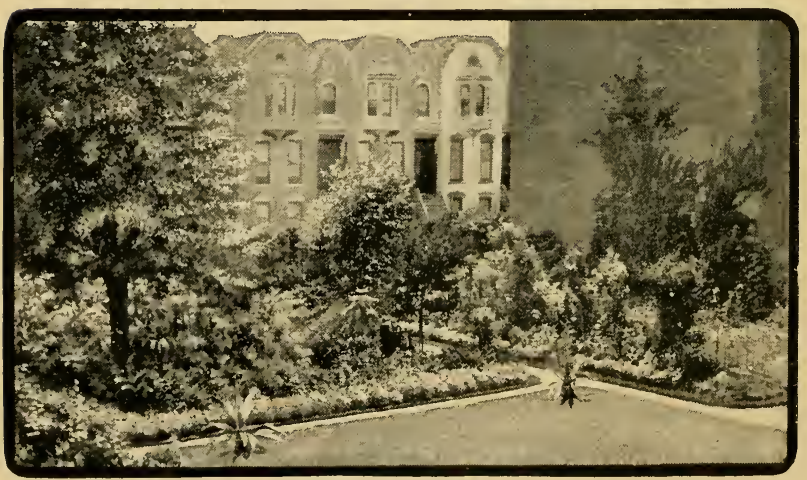

NEAR A STATE CAPITOL. 


\section{LITTLE GARDENS}

HOW TO BEAUTIFY CITY YARDS AND

SMALL COUNTRY SPACES

\section{BY \\ CHARLES M. SKINNER}

AUTHOR OF

NATURE IN A CITY YARD, FLOWERS IN THE PAVE, ETC.

ILLUSTRATED

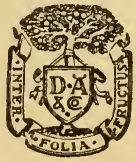

NEW YORK

D. APPLETON AND COMPANY

1904 
Copyright, 1904, BY

D. APPLETON AND COMPANY

Published May, 1904 


\section{P R E F A C E}

THERE are many books on gardening for the few who have large estates, and few, if any, for the many who have small ones. This volume is designed for the uses of the family whose lands are a house lot. It is not a manual; it is not a grammar upon the science or subject of small gardens; it is a series of hints and suggestions, which may be unendingly diversified. The writer has drawn upon his own experience for most of his material, and on his imagination for his plans, but he has taken the word of authorities on some matters respecting the plants to be used, since it is not within the fortune of people who cultivate small gardens to acquire a close acquaintance with all the flowers that can be grown between the thirtieth and the forty-fifth parallel. City yards are usually dusty, weedy and neglected, the theory of their owners being that it is not worth while to cultivate patches of 


\section{I T T LE GARDENS}

ground so small. The need is the greater because of their smallness. There is so little natural beauty in the town that we can not afford to neglect the chance to extend it. All the world smiles in the fields, and we have only to go to them to share their cheer; but the smile of a flower in the little well among the bricks and timber, that we call a yard, sheds its brightness where it is needed most. 


\section{O N T ENTS}

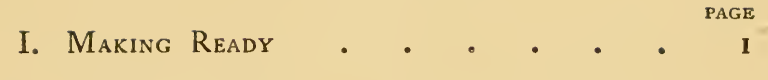

II. The City Y Y

III. The Country Yard - $\quad \cdot \quad \cdot \quad \cdot 8 \mathrm{I}$

IV. Color • • • • • • • • 113

V. Flowers in their Season • • • • 123

VI. The Choice of Flowers • • • . I 44

VII. The Wild Garden . . . • . 205

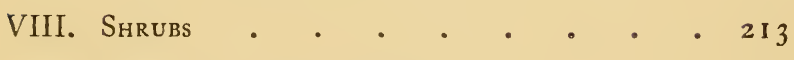

IX. Water in the Garden • • • • • 226

X. Decorative Material • • • • 235 



\section{ILLUSTRATIONS}

$\left.\begin{array}{l}\text { A City Back Yard } \\ \text { Near a State Capitol }\end{array}\right\}$ • • . . Frontispiece

Results in a Contracted Domain . . . . 30

A Garden and Something More . . . . 64

On the Outer Edge of a City . . . . . 64

Roses in Profusion . . . . . . . 92

A Window in Ohio . . . . . . 126

Shade and Bloom . . . . . . 158

Beds of Lettuce . . . . . . . 158

A Window-box and Ampelopsis . . . . 188

A Pleasing Vista . . . . . . . . 218

Diagrams of Yards, on pages $28,32,4 \mathrm{I}, 43,50,51,53$, $57,59,61,65,66,67,68,70,71,77,78,101$, $102,104,105,108,109,115,214,231,238$. 



\title{
L I T T L E G A R D E N S
}

\author{
I \\ MAKING READY
}

MEN are becoming so notoriously addicted to their own society that they miss a good many improving and pleasant companionships. They are forgetting what soil looks like, in the cities. Think of it! In Manhattan only a hundred homes or so are built in a year, and the number grows less and less, while tenements multiply by thousands. For the millions there is no ground: only asphalt and flagstones; and miles and miles of thoroughfare have not the shade or color relief of a tree. Some pathetic show of the primitive need and lingering instinct for good green earth is made in the window-box that we may see on the sill of a fourth-floor front, or in a geranium striving out of a tin can on the fifthfloor back. Nay, in summer I can show you 


\section{I T T LE GARDENS}

where tomatoes are growing in soap boxes, on the fire-escapes: but this is where Italians inhabit, and they are thrifty.

Notwithstanding these hardships, the prediction of the scientists that in the year 2000 everybody will live in New York, and the last morsel of its soil will disappear under a load of masonry, is destined not to be fulfilled. A few positive atoms will continue to escape the magnetism of the metropolis and try to bear with life as it may have to be lived in suburbs like Philadelphia, Boston, Minneapolis and Hohokus, where, at this writing, it is still the fashion to occupy a house, and to have a yard. Much virtue in yards. It is for the moral and mental sanity, no less than for the bodily well-being of the citizen, that he shall go to the earth, now and frequently, to renew liking and confirm kinship with other and more delicate forms of life than his own. He may be slow to read the lessons that are published in the leaf and flower, and may not want to read them after he knows they are there; but in occupations under the sky he is taken away from a hundred artificial distresses that beset him under the ceiling; for happiness 


\section{A K I N G R A D Y}

is largely dependent on the physical state, and that is never at the best in the shop, the office, or the drawing-room. It is, then, worth while to have a yard, and use it, if only to forget stocks and crimes and bills and government. If the victim is disposed to tempers, he can wreak them on the weeds, the time never having been, nor destined to be, when his yard will be free from these vegetable upstarts. And the cleaner he can keep it from these intruders, the more ample his self-complacency, and the more his enjoyment of its acquired and natural scenery.

And one can do a surprising deal with his yard if he will tend it with affection and humility. Why, if it came to a tussle with hard fortune he could partly outwit adversity by selling his flowers and raising vegetables. Don't cry out upon me. If you have ever farmed one, you know that I speak within bounds when I say that out of an ordinary city yard you could grow enough to keep a family for a month. The family might complain a little, and would probably desire to exchange some of the crop for eggs, dairyproducts or champagne, yet there would be variety. You should have asparagus, lettuce, cel- 


\section{I T T L E GARDENS}

ery, tomatoes, corn, beets, peas, beans; for a warm day, a cucumber; for a cold one, a pepper ; and quite likely, a few berries, with such dandelions as grew wild in the interstices of your yard for greens.

Again you say, Preposterous! No, for I can lead you to a yard behind an old house in the city that is occupied by a mechanic, and I can show his farm in operation. He will be glad to have you look at it, for it is a source of pride with him. He works in a shipyard, where they are raising only hob, at present, and he has only his evenings and early mornings for farming, yet not only has he all the green stuff he requires in the season, but he has some to give to the neighbors, and I testify to the excellence of his lettuce and his celery. His domain is something like fifty feet by twenty-five. But, then, he cultivates it like a Chinaman, and every foot of it is a possibility.

Which brings me to say that when you own a yard you need not devote it to cabbage, unless you are pinched by want and addicted to corned beef. On the contrary, you can make that yard a spot of such charm that the neighbors' boys 


\section{A K N G READY}

will continually beset it, to gather of its opulence, and lovelorn cats will sing o' nights in its shrubberies, secure from observation and projectiles. And when I speak of yards I have in mind, not the spacious lawns and gardens of the country, but the strip behind the city house that is given over, on wash-day, for the sunning of the family linen, with the revelations of anatomy and thrift that pertain to that necessity. The yard in town is deplorably small, I admit, and grows smaller, for the canny builder, who used to apportion a house to every lot, has fallen into a habit of putting three houses on two lots, and there are rooms where a man does not carelessly stretch himself without peeling his knuckles against the wainscot on either side of him. As a distinguished observer has observed, you can always tell a Harlem dog from one brought up in Brooklyn, because the Brooklyn dog wags his tail from side to side, while the Harlem dog, bred to the restraints of flats, wags his up and down.

We will take the Brooklyn, rather than the Harlem measure for the human habitation, and consider, briefly, what may be done with its pleasance. Let us, then, suppose a space of 


\section{I T T L E G A R D E N}

ground in the usual row, divided from the other spaces by a board fence six feet high, overlooked by hundreds of windows in the row of which your house is part, and in the other row, on the next street. If there are breaks in the enclosing wall of residences, that let your eye escape toward fair or misty horizons, so much the better for you, and so much the more likely that a speculator will fill them, presently, with taller and more obstructive mansions. Your yard measures, say, twenty-five feet by sixty feet, and in that space we can not look for much variety of soil or climate, although a yard of less than that dimension, that I cultivated for a while, had the most various soil that I ever worked in. It was a joy to the archæologist, for it contained hoopskirts, false teeth, bird-cages, bones, rocks, tinware, indeed, I hoped to reach mastodons, but I came no nearer to that discovery than to upturn a pet turtle who had buried himself in a bed of cannas, and had overlooked his customary day for resurrection in the spring.

And so long as variety in topography and natural products is denied to your yard, I would take the hint: conform to circumstances and try 


\section{A K I N G R A D Y}

not to make it too excitingly variegated. Don't attempt an Italian garden on twenty-five feet by sixty. Don't build terraces, or flights of steps, unless the land slopes, or plant all the different things that the seedsmen's catalogues offer. Keep to a simple scheme. Indeed, it is a mighty pleasant yard that has just grass in the middle, and roses all around. The trouble is that roses will not bloom forever; and again, most folks do want a little versatility in their crops. And all the same, I grow more and more to believe in a certain amount of formality in a garden. Proper division of the space at your disposal gives the best results, because you practise economy. The wild garden is a joy when there is enough of it; but a back yard left to whatever happens to grow there is unsightly, and if you throw about a quantity of seed of wild flowers, and let them come up without tending, the result is not much better. There will be no color harmony in your arrangement, for there can be no arrangement, and the plants will choke one another. We may enjoy wild life, but we do not decivilize our homes for that reason. We would not fill our parlors with the lumber of the woods, 


\section{I T T LE G A R D N S}

precious as it might be to us in the camp, or even the country cottage. The garden is a part of the house, and a part of us.

Let us, then, agree that we can not represent all outdoors in the oblong behind our house; hence, we will lay it off in a way to please the eye and nose and understanding. We have, of course, to consider sun and shade. If the house is on the north side of the street, the yard will be more constantly in shadow than if it were on the south side. (I am humbly supposing that this Work is not circulating in the southern hemisphere.) The shadow cast by the house may spread half across the yard; hence, the flowers that like the sun will not do their best close to the building, but will ask to be bedded as far from it as possible; yet this does not mean that you are doomed to have no vegetation near the house. Why, it would be worth while merely to raise ferns and moss.

If yours is the usual city yard, and not shaded by monster hotels, flats, factories or shops, it should have the sun, however, in the summer, when you need it least and your plants need it most. And a plant that can have, say, five or 


\section{A K I N G R A D Y}

six hours of bright sunlight, has nearly all it needs for health. It must have a good soil, and if your garden-to-be is caked over, you must spade it up. Many yards in town have a hard and leathery surface, like that of the plains in the days of the overland trail. The plains had been crusted by the beating feet of buffalo. They were almost as if asphalted, and no vegetable life appeared there except sage and cactus, with grass and cottonwoods only in the river-bottoms. When these desert lands were broken by the plow they proved to be rich in phosphates. It may be that the like will happen in your yard. But it was no buffalo that pounded your soil into the semblance of clay: it was wilder and more fearsome beings - the boys next door, and Mary Ann. We have to consider these dynamic forces in devising our garden, but we have first to spade and fertilize, cut the sod to pieces, throw out the stones and tomato cans, prepare strings or trellises for vines, and plan the beds. Drainage, too, and prevailing temperatures must be thought upon. By drainage is meant such as results from the porousness or heaviness of the ground, and the natural slope of it. You can not do much 


\section{I T T L E G A R D E N S}

in respect of artificial drainage in a yard, because it is just like the folks next door to complain, if you pipe your rain and melted snow into their premises. Nor is it usually so wet in the East as to require the services of an engineer in laying out a yard. So long as rain-water or thawed ice do not lie in pools on the surface, there is no occasion to trouble yourself about this matter. If your yard has a solid rock foundation at a depth of only a few feet, or if it is stiff and clayey and sheds moisture, then it will probably be necessary to have in an expert. Your vegetable is a thirsty creature, and commonly your yard will not only drink all that the heavens provide, but will ask an occasional showering at your hands, but this supposes that it is growing in a light and fertile soil; not in one that is covered by stagnant puddles for days after a shower. Beware of these puddles. Mosquitoes breed in them, and mosquitoes carry malaria. If the soil is stiff it is easily possible to give a wee slant to the surface of the yard, trenching it slightly at the center, or at one side, or toward a far corner, and where the water is deepest to install a connection with the drainage system of the house, 


\section{A K I G REA D Y}

or with the sewer, direct. Indeed, modern builders provide this, and you will doubtless find, in a hollow, somewhere about the premises, the head of an iron pipe, grated or colandered, to prevent the escape through it of stones, leaves and grass. Keep this free at all times, unless you find that your plants appropriate and need all the moisture they can get, for in that case, the less of the precious water that flows away, the better.

And while upon this subject, let me urge you not to neglect the watering of your floral charges. Have a hose, or at least, a watering-can, against the droughts so usual to our summers, and refresh your garden in early morning or at evening. Nature's method is not to wet the earth when the sun shines. To that end, it overspreads us with clouds when it rains. I do not actually know that watering in full daylight hurts a plant, though florists assure me that it does, but it is best to do the sprinkling toward dusk, for the reason that it is most economical to do so, the evaporation being less, and the plant getting the whole benefit of the ducking. It is better to water the yard once a week, and give a thorough drenching to it than to dribble a few quarts over 


\section{I T T LE GAR DE N S}

the plants every evening. Gardeners all deplore light watering, and it has this disadvantage: that it does not give to a plant what it wants, any more than a spoonful of drink slakes thirst; that under a merely superficial moistening the roots that should strike deep, in search of moisture, thereby holding the plant firmly in its place and giving it lease of life through the winter, may turn to the surface, and thus give but a shallow foothold. So we must regard our plants as regular topers, whatever their simplicity of countenance. But I have found that a hasty trip about one's yard in town with a watering-can, if not a rapid turn with the hose, is good practise, for the reason that a city is a dusty place and the object of the sprinkle is not to give drink, but to wash the plants free from dust, that they may breathe the better. There is something pitiful, something wrong, in the aspect of a rose or lily powdered with grit or fragments or street droppings, and something unseemly in the covering of bushes with fragments of straw and spots of dirt. The retention of heat by the enormous spaces of brick and stone in a city, and the giving off of that heat through the night is inimical 


\section{MAKING READY}

to the "falling" of the dew that so cleanses and refreshes vegetation in the country. Dew is merely the condensation of moisture in the air, and is caused by contact of the air with the cooled surfaces of the earth. As the dew is less in town, the evening sprinkle takes the place of it. But while watering should be copious once or twice a week, it must not be overdone. In a wet "spell" it is not necessary at all. If our plants exceed in food and drink, they will grow fat and not fine; that is, they will run to stem and leaf, and their blossoms will be few, or atrophied. What's that? They are like some human beings, then?

In his hunger for the soil, that develops when a man-or his wife-acquires a bit of yard, there is a tendency to demand more of it than it can give; to be overgood to it, expecting impossible returns; to spoil it, as we do some children. It is a real delight to play the hose over our garden at sunset and see it brighten under the mimic rain. How fresh and fair it looks, when we have done! Yet it can be harmed with too much drink. Plants that are too much coddled grow dim and weak when the coddling is foregone for 


\section{I T T LE GARDE N S}

a while. One other item: Go over the ground with a rake, or a hoe, if it shows a tendency to harden and pack down, so that the water may reach the roots; even a spading or troweling may be necessary in resistant soils; but be careful not to cut the rootlets and not to heavily jar the plant, for that may shake off its flowers, or displace it, or at least break some of its stems or branches.

But we are getting a little ahead of our plants. We haven't them, yet. Our first work is to loosen the soil, and as you will have trouble in getting a horse and plow through the basement, the work will require to be done with a spade. By a fair output of profanity and industry, men have been able to spade up a yard in a day, and even to do a little work, between whiles. If you move in during the late summer you can not do much toward the improvement of your premises. Buy some showy things from the florist, set them out and let it go at that. Let the youngsters rollick over the ground. Heaven knows they have little enough of play space in the city! If you have children of the playful age, forego the garden, and occupy the yard 


\section{A K ING READY}

with toys, swings, seesaws, and sand-heaps. If a garden is possible, however, prepare for it in the fall, with a spading, taking dry weather for the digging, and pulling out all the big and troublesome weeds before they go to seed. Be sure to do this work while the ground is dry: otherwise the soil can not be easily loosened up, and the weeds that you overturn will be less apt to strike their roots back into the earth than if they and the earth were wet. This rule holds in plowing and harrowing, where they are practical, quite as well as in spading. After the soil has been turned over, it is to be raked level, lawn grass-seed is to be sprinkled over it, and it is then to be rolled-you can hire the rolling and need not buy the machine to do it with-after which, the flower-beds are to be laid off in the spaces not assigned to grass; trees and shrubs, if any, are to be planted, and a little later, bulbs are to be set out for spring flowering.

As the chances are that the yard has been putting up vegetation, in the form of grass and weeds, for several thousand years without much encouragement to continue in the work, it behooves the thoughtful house owner to feed it 


\section{LITTLE GARDENS}

with manures. He can, if he must, wait till the snow is about to fall, so that the sight and odor shall be quieted beneath the white of winter; yet it is better to be brave and endure. You can use phosphates, guano, poudrette, bone-dust and higher-sounding things than these, but there is nothing better than hennery and stable manure. Never use it fresh, for the ammonia is then overpowering, and will burn your plants, and put you out of favor with the family next door. It must be old and well rotted in the compost heap. The manure, of whatever kind, is to be stirred into the ground on a second spading or raking. If plants or trees are standing in the yard during this process no harm is likely to come to them from stable manure, but the chemical fertilizers are sometimes so sharp that moderation must be used in applying them, and it is well not to have them touch the roots of the plants. If the yard is so large, and so open to the street as to admit of plowing, the manure may be strewn over its surface after that operation, and then harrowed or raked in. Odorless manures are much in favor for city use, but for actual value they will never replace the stable sweepings and decayed 


\section{A K I N G REA D Y}

leaf-mold from the woods. They are expensive, too, and they are sometimes adulterated with sand and plaster. As to special enrichments, for certain plants, I opine that there is much nonsense in that notion, and that the common manures are good enough for all the plants that grow. During the winter the roots will be absorbing food, and should show vigor in the spring, but if the soil is poor, if there is a time of darkness and sour weather, or if any disease of malnutrition takes hold on the roses and lilies, let them have a trifle of stimulant: a few drops of ammonia to a pail of water. Indeed, it is well to give a little of this at intervals, say, once a month, through the green season.

Your farm can be worked with very little machinery. You will need a hose, with a reel to wind it on, a rotary nozzle for spraying the grass, and the usual tip, which throws a fine mist or a strong stream, according as you adjust the cock. You will require a lawn-mower, which the comic papers assure us is held in abhorrence by male suburbanites, and not always without reason, for the woman, in a cool and gauzy dress who sits on the veranda while the slave of the 


\section{I T T L E GAR DEN S}

lawn trundles about his Sisyphus burden, little realizes that by transforming the energy needed in "shaving the whiskers off the earth," as one victim described it, the defendant could get himself elected to a first-rate club or a second-rate board of aldermen - in neither of which positions does she wish to find him. I pushed a machine over a lawn in the country one morning, and was displeased to find that, hurry as I might, I could not finish before breakfast. I remarked that it was not a big lawn to look at, but it seemed to take a long time to get around it. "I've made a rough calculation of the distance it is around the lawn-mower course," observed the man who had not guided the implement that day, "and I find it is about five miles." Therefore, oh, dames, be tender of the suburbanite, for the comic papers are not. He has sorrows of which you little dream. But insist on his mowing the yard once in a week, at any rate. You are also to provide him with a spade, a trowel, a sickle, a rake, a hoe, a pair of garden shears, a sprayer for insect poisons and a dibble. Perhaps you do not know the dibble, and it sounds so like a divvle that you may think it is something wicked, 


\section{A K I N R E A D Y}

but it is merely a pointed stick which you jab into the earth-that is, the husband does-and rotates, describing a widening circle with its handle, while the tip remains fast. This digs a pit in the shape of an inverted cone, and digs it in two or three seconds, hence the dibble is useful in planting and transplanting and in preparing places for sweet peas, flowering beans, and the like. An old shovel handle, cut off eight or ten inches below the grip, and sharpened, makes the best dibble. You can have it tipped with iron by the blacksmith.

Most of the hay-crop in the yard will be gathered by the lawn-mower, but you will need the sickle and shears for trimming corners, borders and clumps of grass that spring up about the roots of trees and bushes. If the grass is suffered to grow long it will make troublesome snarls about the cogs and roller of the machine, which will tear it up by the roots, but, what is worse, your turf will be dry, harsh, stemmy and ragged, unless it is kept down; weeds, too, will gain a hold, sow themselves, and increase. By frequent cutting, the grass is kept tender, green and thick, because room is made for the young 


\section{I T T L E GAR DE N S}

shoots, and it is prevented from going to seed. Be careful of your grass. It is the surest and handsomest crop your garden will yield. Flowers last for a little and are gone; leaves unfold, flourish, wither and fall, but grass smiles up at the first breath of spring; it often lasts until the beginning of December, and when comes a January thaw there it is, a trifle faded, yet still green, assuring us that winter is not the seal of death, but only a mask of life. Bright color has its cheer, and we plan our garden for it, but we prize it as an accent rather than a constancy. The blue of the sky and sea, and the green of the earth, are a delight forever.

There is another than esthetic reason for giving a part of the yard to grass; namely, Mary Ann. It may be that Mary Ann has the same delight in art and nature that other people ought to have, and often don't, but surely no other people can smash as many porcelains indoors and so many blossoms outdoors, in any given time. I have seen a garden after a single promenade of this virgin, once out and back, that reminded me of a Kansas farm after a cyclone. You would have said that nobody could do the things she 


\section{A K ING RE A D Y}

did whose feet were smaller than dining-tables, and whose knees were unarmed with scythes, like those attached to the wheels of the Greek battle chariots. Yet she came back into the house chortling a comeallyez and serenely unconscious of injury. If Mary Ann has grass to roll her feet upon she may be willing to let the flowers alone, or at least, to maim, behead and uproot only those that are nearest; and in our own interest, if not in hers, it behooves us to yield this point. If you have a roof or a laundry in which clothes may be dried, so that the usual Monday rejoicings shall not be manifest to the vicinage, Mary Ann may be persuaded to remain indoors, and horticultural possibilities thereupon widen, cheerfully. An offer to let her receive her cousins in the kitchen, every night, if those importunate relatives will visit by platoons and in turn, instead of by divisions and in mass, and a willingness not to inquire where the last butter, sugar, tea, coffee, flour and cider went, will sometimes make Mary Ann amenable to petition. So it is best to give that part of the yard to grass which is nearest to the house, and you need not consider Mary Ann altogether in this; because the views 


\section{I T T L E G A R D E N S}

from your back windows will be pleasanter if the flower-beds are at the back of the yard, where they can best be seen, and where they have the park-like preface of a lawn.

If Mary Ann's feet have made appreciable hollows in your grass-plot, in their goings and comings, they can be filled in with light earth, and the lawn may be rerolled. A smooth and velvety lawn is a delight to the eye, look we never so lovingly on nature in the wild. Perfect grass is not to be grown overnight. In England, where you see it at its best, they have a saying that, to make a lawn requires three or four centuries. We can make one in less time than that in our country, and you may see lawns of almost English beauty among the unvisited wilds of upper Manhattan. There are some estates in that forgotten quarter of the world, soon to be blasted and leveled and chopped and covered with flats, which recall the stately halls of England, not so much in their buildings as in the lovely settings of trees, vines, flower-beds and billowy or lake-like grass fields.

After planting your lawn you will put in your bulbs-your crocuses, hyacinths, freesias, 


\section{MAKING READY}

jonquils, and tulips, and in placing them in the earth, as also in setting out your woody plants, your peonies and your fleur-de-lis, put a bit of old manure into each burial pit before placing your bulb or root there. After all is in place, it is well to cover your yard with a mulch of leaves or straw, if you live in the zone of long, cold winters, and in early spring, when frosts still threaten in our land, which has so little climate and so much weather, protect the young plants, if you observe a falling thermometer. This you may do by inverting pails, buckets or hardware over them, or by pegging down thick papers or paper bags, to be removed next day, or as soon as the sun shines. Still, plants are a deal tougher than they look, and the early ones, that the poets call fragile and tender, will defy weather such as will wilt a tramp. Your bulbs will throw up shoots while the nights are sharp, and will invite the insect with color and perfume while yet the insect is heavy with its chrysalis sleep. Then come the budding and the universal upspring, and from that time, through two-thirds of the year, your garden will be a place of beauty. 


\section{II}

THE CITY YARD

THAT your estate of twenty-five by sixty may be a place of beauty, in truth, you will determine on the form of it in the fall, so that it may come into bearing early, and so that there may be no disfigurements and eliminations through the correction of mistakes, after it is in flower. Let your lines and forms be simple and direct, and use color and foliage in masses, instead of in detached bits. Indeed, massing is necessary to simplicity. Put like with like, and aim for broad effects, rather than for diversity. Be formal rather than negligent, but do not carry formality to fantasy and grotesqueness. And here another problem offers: Shall we make a formal garden where all the surroundings are formal, or shall we seek to offset formality by lines of grace and freedom? I grow more and more to believe that we must civilize our surroundings when we break away from nature so completely as we must in 


\section{THE CITY YARD}

town, and that it is a parody on nature rather than a reminder of her beauties when we attempt to illustrate the phases of the great world in a back yard. A formal garden enables us to utilize our space most fully; it exposes the whole yard at a view; it gives opportunity for the cultivation of a sufficient variety and of brilliant groups. Harmony is better esthetics than contrast, wherefore the fixity of the garden plan conforms not disagreeably to the stubborn architecture that hems it in. If the yard is a large one, then, indeed, we may undertake to create some landscape and to soften the environment, but it is hard to make a substitute for fields, woods and hills in a place where Mary Ann has been drying the clothes. The Japanese, it is true, have the country in little in a quarter of an acre; but that resolves itself, after all, into another phase of formalism. They have miniature gardens, mountains, lakes, lawns and forests; for by pinching off the roots of maples and evergreens they confine those trees to a height of one or two feet. They induce a dwarf habit of growth. I once owned a couple of cedars that were fifteen or twenty years old, and were less than six inches 


\section{I T T L E G A R D N S}

in height. The Japanese landscape effects are on the same microscopic scale as these trees, and the seen-through-the-small-end-of-an-opera-glass gardens would not go well with four-story houses and the dust and ugliness of town. With the slight and pretty dwellings of the Japanese they are possible enough.

If you are resolved on bringing nature into the town, it will signify that you are a man whose sympathies are not all for humanity, but have some reach into the world where gain and politics are not; while this, in turn, will mean that you desire to be yourself, rather than to be other men, taking color from nature, rather than society; hence, you will esteem privacy, at least, somewhiles, and will seek rather to escape the observation of the precinct than to be the focus of it. Therefore, your first care will be to close yourself about with vegetation. If it is permitted, you will plant trees at the end of your yard, train a hedge of privet along the sides of it, and mask your house, back and front, with ivy, ampelopsis, honeysuckle or wistaria. You will live in a jungle, barely penetrable by prying eyes and, I hope, as delightful as it is secluded; and 


\section{THE CITY YARD}

although you may reserve patches for flowers, the first aim will be to secure rich and concealing greenery. Now, the effect of space can be gained in narrow limits only by evasions and concealments. If your whole yard stands disclosed, if nothing is suggested or left to fancy, if there is no mystery, it must of need seem small, and its charm will be that of accuracy. Our informal yard will require trees or bushes tall enough to break the prospect, and to that end we must plant them in sinuosities, instead of right lines. Also, it will be well to place the smallest near the house, for it is another rule in gardening, so far as gardening can be confined by rules, to bring the smallest near, where the eye would otherwise overlook them, and let the tall, strong plants speak for themselves at a distance. Thus your wilderness will recede in ever-heightening masses, the remoter growths suggesting the edge of a wood into which one might penetrate for more than-well, six or eight feet. Here, then, is a scheme to gain this effect:

The yard is given over to grass, chiefly, for, as there is much shade, flowers will not bloom copiously; and, again, if you insist on flower-beds 


\section{I T T L E GARDENS}

in addition to so many shrubs and trees, the picture will be crowded and confused. There is not the least objection, however, to trellises enclosing the whole yard, and supporting sweet peas, trumpet-vine, passion-vine, honeysuckle,

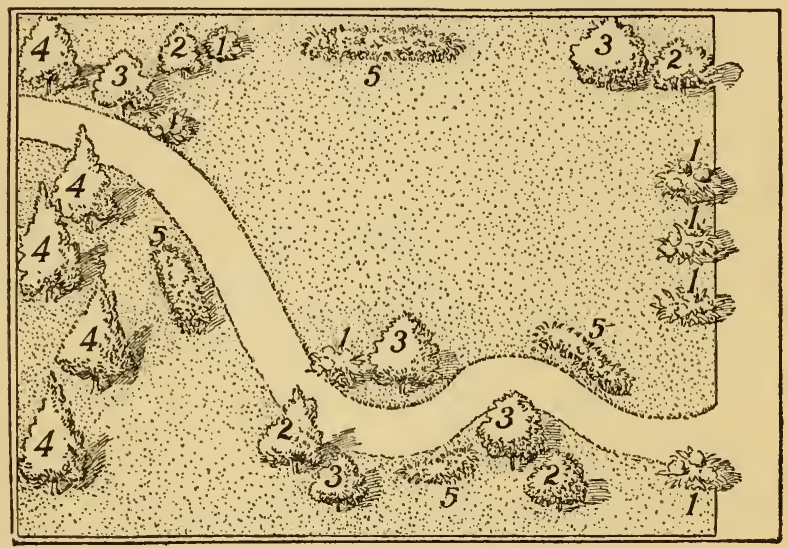

Fig. I.-I, 2, 3, Shrubs; 4, trees ; 5, flower-beds.

moonflower, morning-glory or climbing roses. Such vines need not encroach on the yard itself, and if they are carried to a height of eight or ten feet they will add much to the seclusion, both actual and apparent. If flowers of smaller habit are used, wild ones will better consist with your plan than tame ones. I am fond of the wild 


\section{THE CITY Y A D}

things, and have grown them with success in a city yard, my golden-rod standing head high, with stems like willow branches for girth and stoutness; my buttercups unfolding in a very cloud-hundreds of shining blooms; my daisies starring the perspective with copious silver; and I know a front yard, two minutes from one of the busiest streets in New York, that, in the season, is beautiful with wild asters. In the plan, the objects numbered I are hydrangeas, rhododendrons or any other tough bushes that mark the beginning of the yard without too much exactness, and are not high enough to conceal those a little beyond. Those marked 2 are taller; weigelia, black currant, syringa, rudbeckia or any such, while number 3 are higher yet: privet, lilac and shadbush. The forms marked 4 are trees, preferably pines, hemlocks, firs or spruces, if your yard has fresh air and is near the outskirts; if not, don't doom these children of liberty to the crowd; choose, instead, some deciduous trees, or even erect a narrow arbor, or a trellis, to extend across the end of the yard, and clothe it heavily with vines. Number 5 stands for flower-beds. The arrangement in this manner of planting, 


\section{I T T L E G A R D E N S}

which can be varied to any extent, has for its object the partial screening of the distance, so that the eye merely guesses at a beyond which isn't there, or is a different sort of beyond from one that you prefer to guess. The eye travels along a path that loses itself among syringas and lilacs, from whatever point near the house you may view it. The object of a path like that is rather to invite your eyes than your feet, for its windings suggest that it rambles on indefinitely. If your neighbor, dos $\grave{a}$ dos, falls in with this device, and will plant a few trees at the back of his yard, so that your forests adjoin one another, save for the fence (and if you are good friends that need no more stand in your way than if it were the constitution), your wild properties become almost impressive in extent. The objections to the plan are that it is much brokencluttered, the housewife may say-and that grass will not grow well under trees, for it demands sun; but it has the advantage that it offers meditative walks, and a chair or bench or hammock placed under the trees, or in the arbor, permits you to enjoy a book, or the cool and fragrance of the evening, or the warmth and perfume of 




RESULTS IN A CON'TRACTED DOMAIN. 


\section{THE CITY YARD}

your cigar, in relative security against the hundred and fifty eyes at the back windows. Your forest will require frequent trimming, for unless you keep the vistas open and remorselessly check the attempts of the lilacs to fill the whole yard, you will presently have to fight for admission to your own premises. A more serious objection is that children, strangers, and Mary Ann, who is a law unto herself, will by no means travel on the path, for it is human nature, and especially American nature, and often a most excellent quality, to go straight to a designated object, considering grace and the neighbors not a whit; hence your path will be much neglected, and your grass much walked on. Even in parks, with police on duty as exemplars and enforcers of taste, people will take short cuts to save a bend.

It is, therefore, with hesitancy that I suggest a still more radical but more conventional use of the curve. It is so completely artificial and against likelihood that I would hardly admit it here, were it not that I know people whose houses are only thirty feet back from the street, yet they must have a curved drive, in both directions, to the front door, and a porte-cochere for 


\section{I T T LE GAR DENS}

the shelter of visitors. Well, here is a double curve: the oval. Quite like a frame for a miniature, isn't it?

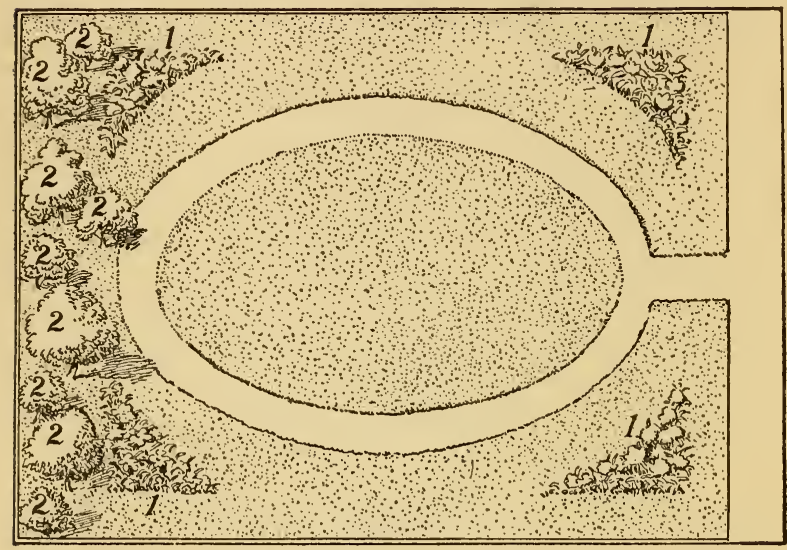

FIG. 2.-1, Flower-beds; 2, trees and bushes.

Mind, I don't say that this is pictorially bad, if I did make it myself, but only that it is unAmerican and impractical; that the young Indians in the family, seeing their bat or ball where they dropped it, at the farther end of the yard, would make a rush for it, and would wholly neglect the appointed means of arriving. Nobody would toddle around the oval but old persons, or guests whom you had invited to admire 


\section{THE CITY YARD}

the effect, and who were looking for more important favors in the future. But if there are no Indians, and no Mary Ann, the oval lawn is rather pretty, don't you think? Unless you were to plant flowers in a smaller oval in the center, there is no place for flowers inside the walk, and you must have grass. It is the symbol and the proof of plenty. Our soft-breasted earth yields treasure to her children for the asking, yet never in such wise as when we cut the grass. For other crops are planted by men's hands; they have sown and watched and weeded; they have spent their strength in plowing, harrowing, watering, spraying before the harvest was to be gathered. But grass is the world's freest gift, and the freest is often the finest, like the night spectacle of the stars, and the splendors of the sunset. Grass grows in the tropics, and the arctics, too. In the warm darkness, where the seed has sunk, strange chemistries go on: the grain of weightless matter has thrown out its threads of white, to steady the blade it will presently send up and grip the earth. These blades, in multitude beyond the swords of all the armies, thrust aside the sand and stones and flourish, shining, in our sight. Wonder of 


\section{I T T LE GARDENS}

life, that the woody atom, dropped into a morsel of soil, has been able to take to itself, not only the warmth of the sun and the wetness of the rain, but the very substance of the planet, and make inert mineral turn green and breathe! For herein is God; herein is man to see his own continuance; here is the like of all greater creations, and the miracle in the spear of grass is not less than that of the revolving worlds.

Have it near your eye; let it creep to your door; for this clothing of the globe is fair to all the senses. What wonder that the farmer, walking in his fields, shines his content at his eyes when all about him is this urging and increasing life. It falls in his service without the coming on of bitterness. Each hillock of drying grass utters fragrance, and is a lure, instead of a reproach. Every blade has had its day and has come to the end of it in fulness of life and exuberance of spirit. It is charged with myriads of glistening atoms of silica, which have given strength to it to stand erect and hold its flowers to the sun. It is yet strong with the firmness of the rock. And that strength shall pass into the fleetness of horses; sheep shall eat and clothe us with the 


\section{THE CITY YARD}

warmth that the grass has borrowed from the summer; meek-eyed cattle with sweet breaths shall return it to their masters in food and drink. And the grass-blade has a power, that we have not, to feed upon the ground. We of dainty stomach need that others shall live first, and give their lives to us. It is, then, no less a moral law than a law of nature that we shall fulfil destiny by giving of ourselves for others, even like the grass. We stand firmest and highest when we stand alone, yet our service is for all, and according as we stand apart we have the more fertility to give. In this again we are as the grass. We are not as if each were an entity; we are only of the type; but as we increase, so shall the type prevail. Like the grass, we must convert the dark and hard to brightness. The lesson is something obvious, yet in heeding it we obey the law, not merely of a conscience, but necessity. Therefore, again, let there be at your doors a plenty of grass for your eye and your inner understanding to rest upon.

It is a law in landscape-gardening that a path is to bend only to accommodate itself to the lay of the ground: to go around a knoll, or avoid a 


\section{I T T LE GAR DEN S}

hollow, a pond, a ledge or a tree. You see that, in the first sketch, no such interruptions exist, so we had to make them by planting trees where the curves were desired. The continuous curve in the second conceit is wholly arbitrary; it is a softening of the more usual rectangular lay-out, and is designed to be viewed from the secondfloor windows. The first device is less formal; still, if it mislikes you, (and I don't like it, altogether,) or if the folks next door protest that you have no right to plant trees that will throw a killing shade on their flower-beds and extend their roots under the fence, to the stealing of moisture-because folks who live next door to people are apt to do just this, being an inconsiderate company-you can subdue your yard to good uses, none the less, and be agreeable, in spite of being more customary than if you raised jungles. If they will not let you have trees, or if, as is more probable, you decide that you haven't room enough, your fence will stare you out of countenance, and a back fence must have been invented as a part of the punishment for leaving Eden. There is no more fearsome beast than your back fence. It is of close-fitted boards, 


\section{THE CITY YARD}

six feet high, and painted white or drab. In New England they make a color that is used or found nowhere else, I believe; a blend of brown and lead that must have been inherited from the garb of the Puritans, hence, is as far from joy as colors can be; and this doleful hue, a stain of original sin, they delight to smear upon their fences. It may be the contemplation of this color, in the fences of Cambridge, that produces such frantic outbreaks of conduct in Harvard, for aught we know. But as you go southward you see less of this melancholy, and an attempt to simulate gaiety with buff or whitewash. If you find it possible to agree with the man next door, or if he consents to drown his offspring, you can tear down the structure; or, if a partition is really necessary, you can plant box, or privet, or even a row of lilacs; but, be sure of your man, for he may have saved an urchin child from the sacrifice, or he may own a large and vehement dog of the breed that delights to leap over obstructions and riot over forbidden premises. There will be a sad to-do, in such a case, over the uprooting of the hedge and the reversion to boards; but-whisper! You can let the hedge remain, 


\section{I T T LE GARDENS}

and run a barbed wire or electrified netting along your side of it. If you have a fence, make it as innocuous as possible by coloring it a light and cheerful green, to conform to the vegetation. Do not paint it: stain it; and don't, for goodness' sake, make it a bilious green, but a yellow green. That shade of yellow which in the speech of the commoner is denoted as "yaller" suggests liver complaint; but yellow is a color to use without a green admixture, if your yard is a haunt of shadows, and needs inspiriting. Yellow is the sunniest, happiest color in the world, though we use the name as an adjective of contempt. You remember the yellow suite in Marie Antoinette's apartments at Versailles, and how the sun seems to shine there on the dullest days. With a yellow or yellow-green fence, and such sparks of golden light splashed against it, and over the sward, as Persian roses, marigolds, nasturtiums, coreopsis, zinnias, buttercups, rudbeckia, chrysanthemums and cannas, you will have a remedy against the blues. If you merely rent the place, and the landlord, being a man without a glimmering of taste or a prompting toward helpfulness, declines to stain the fence, leaving it cov- 


\section{THE CITY YARD}

ered with whitewash or shiny paint of an ugly or staring color, be not as one without hope. Drive pegs into the ground, fasten strings from them to nails in the top of the fence, plant morning-glory, and in a few weeks the dismal object will be hidden from sight, while you will be able to spend most of your spare time in pulling up little glories that will have seeded themselves all over the yard. The Calabrian invasion of America is alone to be compared with the enthusiasm of the morning-glory for expansion.

If the people next door do not object-and why should they, since they share the show?you can erect a trellis clean around your yard for the more and better exhibition of the other climbing things and the increase of privacy. A substitute for a trellis is a strand or two of wire carried above the fence top for a foot or so by pickets; but be careful not to impose too heavy a burden upon the wire. A mass of vegetation, especially after a rain, or a showering with the hose, weighs twice as much as you tell yourself is possible.

Having, then, composed your mind respecting the fence, and come to the conclusion that a 


\section{I T T LE GARDENS}

conventional design for the yard is more suitable in a city than the first plan, let us see what can be done with our space. Suppose we try something formal-no Italian garden, bless you, but one that shapes itself withal to the size and form of our reservation, and better, on some accounts, for a front yard than a back one; only, if you have flowers in the front yard, you will have most of the children of the neighborhood there; hence, you must add ferocious bloodhounds and awful serpents to your ménage.

The scheme is simple: a central walk, ending at a semicircular bed (4), with a small tree, mound, rockery, bench, niche or conspicuous foliage plants; strips of lawn on either side of the way, and parallel beds beyond the lawns ( 1,2 and 3 ), the first devoted to plants of low growth, the second to higher, and the third to the highest, with a trellis still behind and above them, if you like. The exhibits are thus arranged in steps, so that all are in view at once, and the show of bloom can be superb. In fact, if the yard is dished - that is, if it hollows a little in the center-it can be terraced, the platforms ascending in rises of six or eight inches; but that sort of thing is to be 


\section{THE CITY YARD}

avoided, ordinarily, because terracing means retaining walls, and masonry means just so much room taken from the cultivable portion of your domain; then, if it is not upheld by a front of brick or stone, as well as a strengthening addition to the fence, your terrace will wash down in

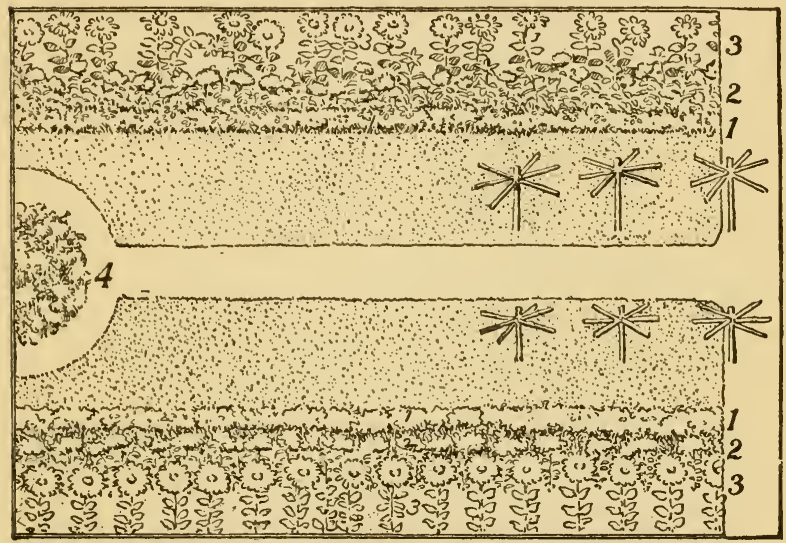

FIG. 3.-1, 2, 3, Parallel flower-beds; 4, semicircular flower-bed.

a heavy rain or thaw, and become unsightly; and, lastly, such things require to be done on a large scale, or they appear fussy and overdone. The uprights in the diagram stand for clothespoles, if the domestic economies require them. It will be noted that they are placed on the lawns; 


\section{I T T L E G A R D E N S}

hence it is not incumbent on Mary Ann to waac in among the heliotrope and mignonette-dainty little things, so suggestive of her own dainty self ! Or, revolving clothes-dryers, or poles with arms that project like spokes, may be erected so near to the house that nothing but Mary Ann's desire to gambol will project her into the flower-beds. The advantages of the plan here submitted are simplicity and compactness. The yard is treated as a flower-bed and a lawn, rather than as a series of beds and lawns. There is no lost space. The lines follow those of the fences and party walls, and have not a particle of originality or character. Your flowers will have something of the appearance of exhibits on the shelves of a museum. Hard, set form will, therefore, be an attribute of this device. It can, however, be modified by the insertion of a central bed, the side beds being curved along their faces to conform to it geometrically. This breaks the severity of the plan somewhat, yet it is still rigid, and unless the neighbors had a good deal of green that appeared above their fences you would feel that you had more than your share of flowers, and they the less. 


\section{THE CITY YARD}

It would be better if the central circle were a pool or a fountain than a flower-bed, if circumstances permitted. That would relieve the appearance of crowding which would result from the addition of still another bed to those that occupy so large a part of the surface. If you

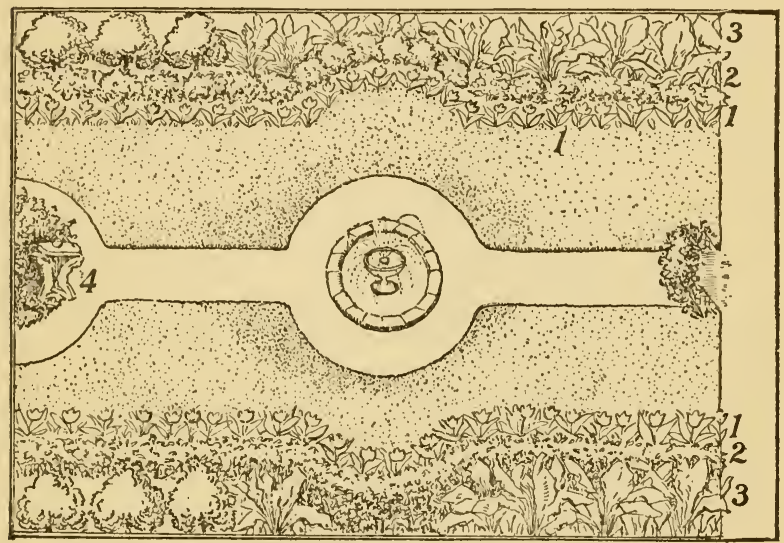

FIG. 4.-1, 2, 3, Flower-beds ; 4, sun-dial.

would cultivate few varieties of flowers, but have a quantity of each, a division of this sort commends itself. If you filled bed number I with tulips, number 2 with hyacinths and kept number 3 for tall and hardy flowers, there would be a rare bravery of color and great delight of fra- 


\section{I T T L E G A R D E N S}

grance in the spring; then, after the fading, you could take out and store the bulbs for fall planting, and fill their places with summer bloomers. It is one of the temptations to a yard owner to work his ground to the limit, having so little of it; and while it insures constant bloom, to buy potted plants at the greenhouses, plunge them into the soil, keep them for a fortnight or so, then cast them out to make room for novelties, your real gardener will not do this. To say nothing of the cost, it is best to grow up with the plant children, to know their traits. You love them the better-pretty dependents-for ministering to their needs, and they reward the care with docile behavior and a cheery aspect. My own choice for a yard is for a preponderance of perennials, the good, hardy, reliable, free-bloomers of our grandmothers' gardens, that we can watch for in April and May with a certainty as absolute as the rising of Orion a few weeks earlier.

The fixity of this arrangement in strips will make the yard seem longer, for when we break lines of that kind we seem to shorten them. We could soften the asperity of the plan in sundry 


\section{THE CITY YARD}

ways, as by erecting an arch of wire at the entrance to the path, and training roses over it, or building an arch, midway, to span the yard itself and covering it with a vine. The result would be rococo; there would be a harking back to the Watteau and Boucher era, to the "hour, flower, bower" age of sentiment; and I am better in favor of as wide a space as the yard will give, enjoying the grass and reserving tall bushes and vines for places near to or against the fence. An arbor, if you must have one, should be of more substance than an arch of wire, and whatever large object we may elect to place as ornament in the yard-for our composition must have a central point of interest, a focus - is better at the end of the vista than the beginning of it, since we shall see it a hundred times from the door and windows to once that we will look toward the house. And as we shall see the yard oftenest from the windows, it is wise to have some equivalent matter to take the place that in a picture is occupied by the commanding figure, or the high light. Statuary needs space, and it needs to be good. But for this I should consent to a small and modest figure, half hidden by 


\section{I T T L E G A R D E N}

flowers and shaded by branches at the spot marked number 4 in the third plan, the trees behind the focal point in the first. White is all light, but it goes well with nearly anything. Still, we have to remember that marble figures are fragile and expensive, and a bronze nymph or satyr that had taken on the green of age, would best harmonize with its verdurous environment. Whatever you do, don't get one of those smirking, insipid statuettes of Flora, Ceres, Hebe or Ganymede that you find on the lawn of the parvenu-things that belong with the tatting tidy, the lamp in petticoats and the plush album. Nor must you buy a metal deer, elk, bear or lion to lord it over the premises and, assumably, to feed by night on the rhododendrons. We all know that such animals do not prowl about town yards. With the brassy freshness of the foundry yet upon them, they have as much relation to your posies as so many pounds of stoves. In fact, you are not pledged to use statuary. There are urns, sun-dials, jardinières and fountains. You may attach a fountain spray to your hose and turn on the water in the evening, and the sparkling current, leaping from an ambush of cannas 


\section{THE CITY YARD}

or marigolds will make a really pretty episode in the scene. In town the water will be low, just when you want to use it; then you may feel bashful about having your neighbors discover the fountain when they have trouble in getting enough to wash the dishes; so in that case, there remain the other adornments: a vase of bronze, for example, to be filled with pansies or nasturtiums, or a jardinière, preferably of Chinese or Japanese make, and of celadon, blue and white, or pale-green porcelain, in which may stand a rubber-plant or palm; or, a box with ornamental handles, or a painted tub. Avoid the tawdry French and German china; not that all the china from the modern potteries is tawdry, by any means, for the Orientals are now doing some deplorable work; but there is a refinement, delicacy, purity in the best Chinese porcelains that you will find in no other. Of course, the finest single colors in these fictiles are not for exposure to the breakage and the weathering of the garden. They are to be housed as preciously as Raphaels and Oriental rugs-works of art that the world may be doomed to see no more, now that commercialism has invaded the studios and 


\section{I T T LE GAR D E N S}

the Orient, and cheap materials, hasty methods and insincere workmanship are rewarded as honesty and effort used to be.

You need not use marble, bronze or porcelain for your central point of interest. Large and decorative plants will serve. The splendid green of the rubber-tree and the exquisite grace of palms, particularly the kentia, qualify these plants for decorative purposes. The kentia balmoreana is an especially useful palm, less tender, more thrifty, larger and more beautiful in a northern climate than are some of the commoner species. A rockery is not a bad focus for a garden, either. These features may be combined by the exercise of a little taste and ingenuity, thus: a crescent of flowers in the bed number 4 , third plan, a rock pile back of it, half concealed in vines or cacti, a jardinière stoutly fixed in the front and center of the rockery, and a water spray arising from before the crescent. This group of objects, or any such, will pleasantly assert itself, and will both lend and borrow interest from its surroundings. The focus may be shifted to any part of the yard, and so long as the other contents are subordinate to it and not in rivalry, 


\section{THE CITY YARD}

and so that the lines of composition tend toward it, it will remain a focus, and the eye will seek it. Or, for purposes of emphasis, a stout bush, a group of showy flowers, a tree, an old trunk covered with vine, a mass of morning-glory clambering up the pole of a bird-house: these will serve.

Now, it may be that the house is rented, and the owner will not permit liberties to be taken with his real estate. You never can tell what manner of man an owner is going to be, when you sign a lease. A certain tenant whom I know had trained with care and affection a Boston ivy to cover a house front. It was a wondrous relief to a bleakly unimportant street. The vine broke into color early and kept of a polished and healthful green for six months. Along comes the landlord, looks at it, and remarks, "Well, when that stuff's all cut off, and a good coat of paint's put over them bricks, that'll be a good-lookin' house again." That is the sort of being who is likely to object to spading and planting, because they might interfere with the setting out of clothes-poles. A popular kind of yard, of his devising, is this: 


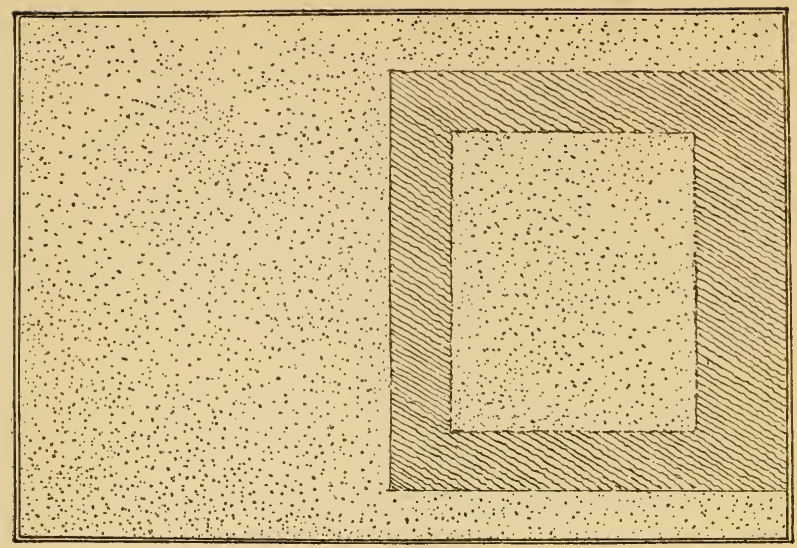

FIG. 5 .

The shaded part expresses flagstones or asphalt; the rest is grass. I had the run of that pattern of yard for a season or two, and as it was the playground of sundry small boys of an inquiring turn respecting vegetation, which impelled them to take plants out of the earth now and then, to see how they were getting on, I did not undertake anything difficult. I adopted the simple scheme shown in Fig. 6.

Grass was the principal attraction here, yet, on a summer evening after a good showering with the hose there was a deal of gaiety in the foreground and among the plebeian bushes that 


\section{THE CITY YARD}

edged the fence. We concealed a part of that fence with glories, sweet peas, wild beans, and tried to conceal the rest of it with vines that made amazing pictures in the seedsmen's catalogues, but that refused on any terms to enter

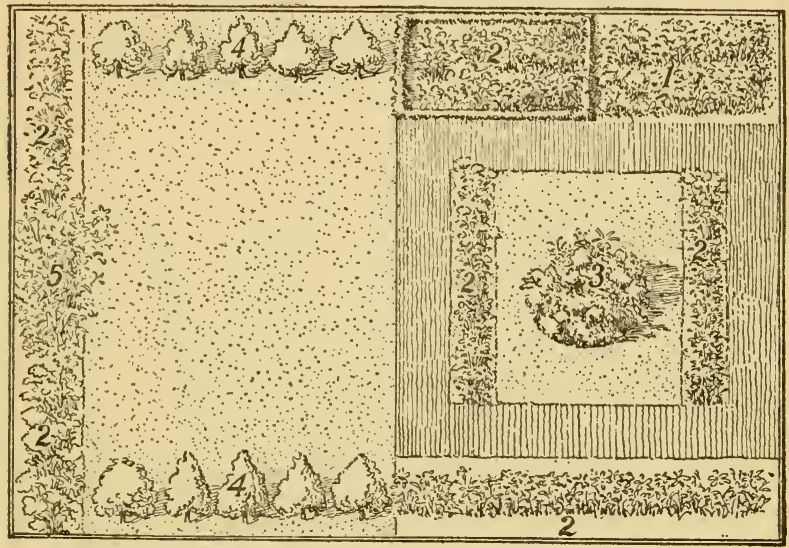

FIG. 6.-1, Wild garden; 2, flower-beds; 3, rockery ; 4, shrubs and hardy plants; 5, jimson-weed.

into the picture made by our premises-a circumstance that filled me with grief and astonishment, for I had supposed that seedsmen's catalogues were as true as the Farmer's Almanac. We had one thing in that yard that nobody else had, willingly, and we were proud of it, namely, 


\section{I T T LE GAR DENS}

a "jimson-weed"-the stramonium, or thornapple, of the vacant lots. This had sown itself in the center of the back bed, and being picturesque of leaf and an oddity among cultivated plants, I spared it. Ordinarily, the sure way to kill a weed is to become attached to it, and give the same care to it that you would to an exotic. It will pine and die. "You never loved a dear gazelle-" and all that sort of thing, you know. But this Jamestown weed endured prosperity with a cheer that it was good to see. It grew and grew until it was the prize among its species. Out in California they have jimsons so big that you can play under them, but I speak now of our humble Eastern variety, which is usually of a dusty, weed-like aspect, rooted among ash-dumps, crockery and old cans, and lapsing into a squalor of age at the first nip of the frost. I hoed the soil about it, watered it, picked off the beetles and grubs, and when the flowers came, gathered them every evening, at least, all but enough to attract the night-moth, with its astonishing proboscis. The determination of that plant to have seed caused it to put forth blossoms in a multitude, and it swelled almost to the dimension of 


\section{THE CITY YARD}

a tree. It was ten or a dozen feet wide and about rine feet high. It screened a ragged and unpleasant view behind us, and was really as handsome a property as many an owner of a private park could desire. There is a hint for any one who cares to act on it.

Adjoining our yard was its twin, but here is what the owner did, and I instance this merely that you may avoid it:

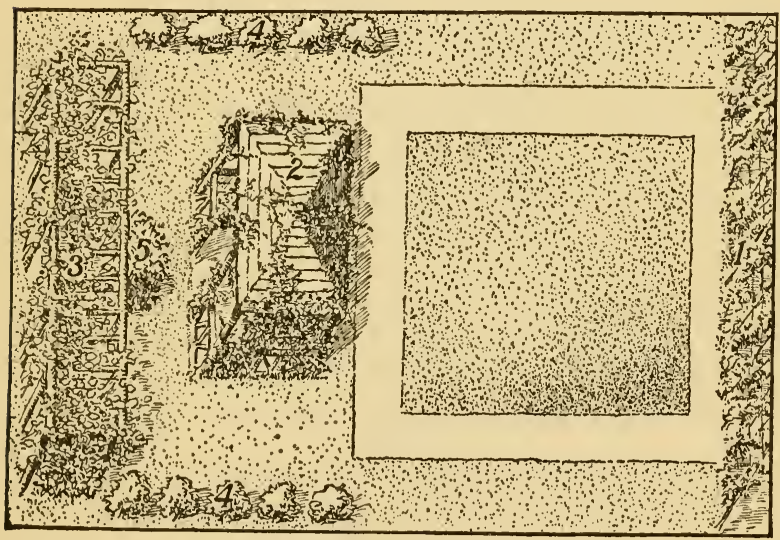

Fig. 7.-1, Trellis reared against the house; 2, summerhouse; 3, arbor ; 4, plants; 5, flower-bed.

Here was architecting on an $8 \times 50$ with a vengeance. The summer-house and arbor were 


\section{I T T LE GARDEN S}

so heavily blanketed with vines that they were dark, damp and soon grew rickety, while the shadows they cast hindered or killed vegetation around them, and the spaces between them and the fence were such wee, pinched areas that they could not be farmed at a profit. The covering of this reservation with planks and lath exemplifies a common tendency of Americans to do too much of everything. They overeat, overdress, overgain, overlegislate, they cram too much into their houses, and up to a certain time of life try to cram too much into their heads. The Japanese have something to tell us in respect of art and life. They simplify them. The rich man in Japan does not show everything he owns. He puts out certain bronzes, vases, wall hangings, crystals, carvings and the like of that for a day or a week, then retires them to his chests and cabinets, and produces another set. He would as soon think of wearing all his clothes at once as of showing all his ivories, porcelains, netsukes, lacquers, kakemonos and embroideries. We, on the contrary, are so fond of show and luxury that we convert our houses into shops and museums, and the same propensity for overdoing is not 


\section{THE CITY YARD}

infrequently seen in country estates with their overfrequent rustic shelters, pewter statuary, and masonry that means nothing except a job for the mason. It is also seen in yards. One yard in my town has a rockery which the owner has bestrewn with statuettes and china, that I verily think he found in the ash-dumps. He does not realize that a house is better suited for such things than is a place where green will grow. I have seen objects in a yard that were not artistic, yet that heightened the interest of locality, or hinted at resources of place or family history. In quartz countries, for instance, rockeries of snowy blocks and chunks of crystal connect the yard with the environing land, and in sundry whaling towns I think we would not spare the ancient figureheads, the flagpoles, the ribs and vertebræ of whales that decorate the yards, any more than the after-cabins of dead ships which have been hauled up into the street to serve as summer-houses, kitchens or homes for the humble. These things, which impart a fine, fishy flavor to shore settlements, are grotesque when transferred to inland yards, unless by a strange chance they conform to some scheme of building or deco- 


\section{I T T L E G A R E N S}

ration in the house that overlooks them. A house like that of the New York Yacht Club, for example, which is a fairly successful, and certainly interesting attempt to continue on land a suggestion of the architecture of the sea, would be entitled to a summer-house in the form of an aftercabin in its yard, if it had a yard; but can anything be more out of place than a boat, serving as jardinière or flower-bed, in a yard five miles from water? So, if we must have constructions and other matters in our ground that are but remotely germane to its normal uses, let us have a thought for their fitness. One of the new-rich families in New York has, in the middle of the drawing-room, a Russian sleigh, highly ornamented with panel paintings, and a palm stands on its seat. Palms are so usual to Russia; and especially in sleighs! Well, of all the-however, it is no worse than putting an old carriage body or boat or packing-box into the garden and filling it with flowers; hardly so bad, in fact, because hardly so obstructive, as putting two summer-houses on a strip fifty feet long.

Assuming that we are bound by the usual conditions as to space and flagging, and have to 


\section{THE CITY YARD}

deal with the kind of yard figured in the last sketch, we can strike out a little more boldly and accomplish this:

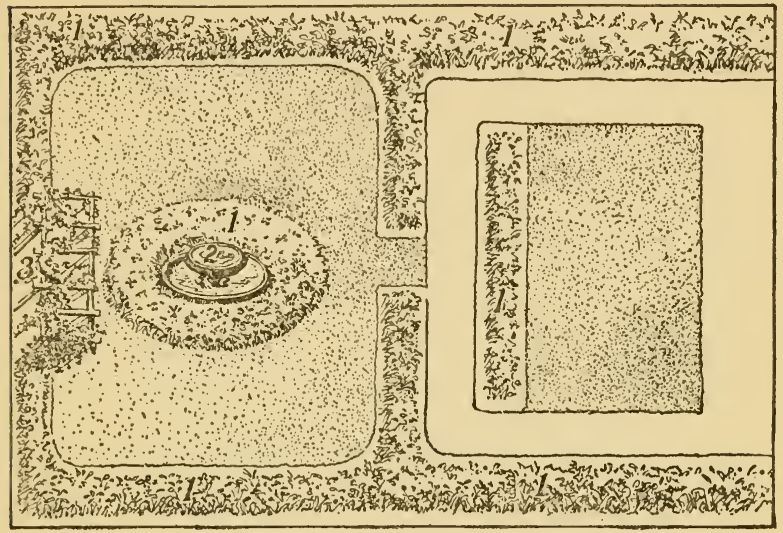

FIG. 8.-1, Flower-beds; 2, vase or fountain; 3. a tree, palm, rustic bench, rustic shelter or statue.

The scheme is formal, but there are curves to offset the angles, and the vase and bench, the distant object higher and larger than the nearer, serve to relieve any possible monotony of form or color-though, really, that can hardly exist in such a little space. Observe that the nearer division of the yard, which is surrounded by walk, is left in grass, except at its farther end. 


\section{I T T L E G A R D E S}

That enables Mary Ann to put out the wash without committing Bulgarian atrocities among the pansies. A continuous bed surrounds the yard, save where it brings up against the house, and throws out two little wings whereby it almost encloses the second lawn also. A space is left between them so as to afford access to this lawn without stepping across the bed. If there is much travel to and fro, the path may be extended around the oval, and so to the end of the yard; but so little space is left for grass that it seems a pity to sacrifice any of it. Even if it is worn a trifle, it will freshen after a wetting, and grass that is slightly injured is better than a walk that is not used. At number 2 a tall plant or group of plants will serve instead of vase or fountain as an effective center, but remember, again, to make it subsidiary in height, mass or color to whatever object completes the vista and occupies the place of distinction in the last bed. A piece of strong-colored Chinese or Japanese porcelain-not garish, mind; only positive-or a Japanese temple lantern of dull bronze, if it does not wear too alien an aspect, and is half concealed by vines and flowers, will 


\section{THE CITY YARD}

serve at number 3 , if the yard is so narrow that a bench, a rustic arbor or any larger object would appear disproportionate to its setting.

Perhaps the yard has a continuous walk, instead of the commoner one that cuts it asunder, and in that case the scheme can be modified in this way:

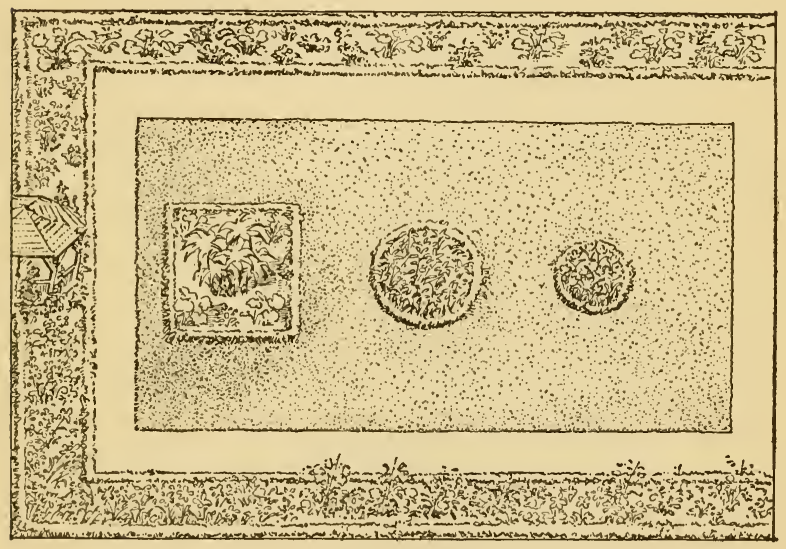

FIG. 9 .

Here the beds surround the yard, as before, except on the house side, while in the lawn space are three other beds, progressively larger as they recede. The effect of this progression is to widen the yard, as the eye roves over it. This 


\section{I T T LE GAR DENS}

arrangement allows of the display of many varieties of flowers, though it is informally formal in its simplicity, and if trellises or wire net are added to the fence, as carriers for vines, and thus give more color and seclusion to your Horatian estates, the neighbors will probably call oftener than they did. Mary Ann, you see, still has the freedom of the first ten feet, and I must remind you that it is not necessary to plant clothes-poles for her. Nowadays it is usual to extend two beams across the yard, running from an upright on one fence to the other. The clothes-lines are strung from beam to beam, fastened to hooks, and a stout tug will haul the line so taut that poles will not be needed to support it. This is an advantage, for poles may fall and smash your ageratum or your salpiglossis - the same being no part of the human system. Mary Ann's fingers are usually buttered when she clutches any domestic materials that you especially wish she hadn't.

A modification of this plan is shown in Fig. 10.

As for the walk, it ought to be narrow. Eighteen inches is enough. You will doubtless 


\section{THE CITY YARD}

make it of gravel, if you have the say so, and it certainly agrees best with the ground, so far as appearances go. Stone and brick, though ugly, have their advantages: weeds and grass do not grow on them, it costs no trouble to keep them

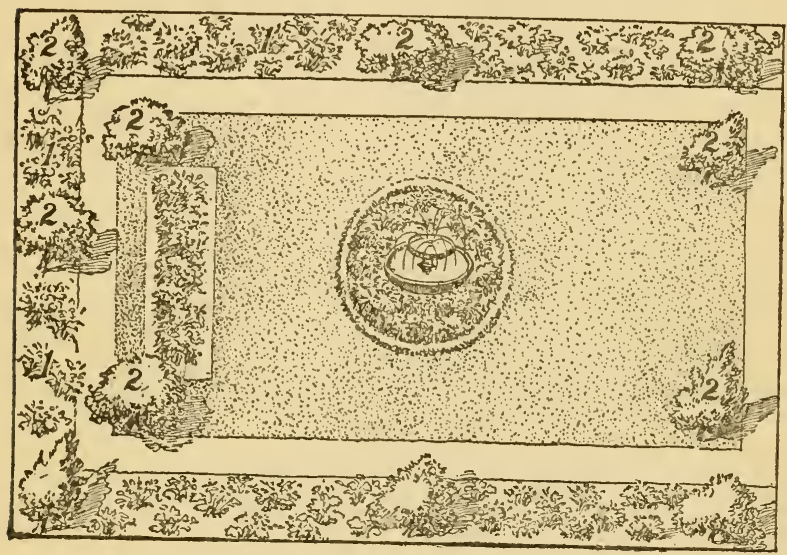

FIG. I0.-I, Flower-beds; 2, trees.

clean, they are not kicked up and put into disarray by heavy or shuffing feet, and they are a check against weeds in the borders. It is not easy to repress the grass when it has no greater obstacle than gravel, which will be moistened in the showerings, but it stops when it touches asphalt or flagstones. And if you would avoid 


\section{I T T LE GAR DEN S}

trouble on this score, let your garden-beds come plumb to the edge of the walk, instead of leaving the usual strip of grass between them. The grass will never leave off trying to possess itself of the whole premises, and the fight against it, when it determines to go where it does not belong, will be unremitting. There is one variety, a coarse and riotous sort, known as witch-grass, that is downright uncanny in its sneaking and its strenuousness. You are transplanting a mignonette, perhaps, out of a crowded spot into a roomy one, and have thrust your trowel four or five inches into the earth, when you strike a long, white, ropy root. Get a firm grip, and lift it, by successive pulls, moving your hold nearer and nearer to its starting-place, until you reach its origin under a bunch of witch-grass and pluck the whole thing. You will find that the bunch has thrown out a star of these roots, some of them two feet long, which are boring and exploring in all directions, quite thankful to you for loosening and fertilizing the soil for them in the spring, and from each of these runners blades are starting toward the air. In turn these blades will become deeply anchored, and will send out 


\section{THE CITY YARD}

root scouts to found new colonies. If witch-grass gets into your yard it is almost worth while to spade it up from end to end, chopping and overturning the sod to freeze and rot it through the winter, and making a fresh start with lawn-grass seed as soon as the snow is off. The war against weeds in the yard is, in object and effect, so like the war against the weeds and parasites in human society that one can readily forbear to publish any parables on the topic. Where a walk occurs between a lawn and a garden-bed, especially if it is a flagged walk, the grass roots are less apt to cross it than they are to underlap a space immediately adjoining. Thus, in one way, it means economy of labor to have as much walk as possible, and we have all seen "gardens" behind city houses that consisted entirely of flagstones, to Mary Ann's resounding joy, and the pained astonishment of moths, potato-bugs and persons who drifted into them. Let us pray not to have that sort of a garden ourselves, and to the end that we may not, we will continue our devising. Only, before leaving the subject of grass, let me caution you against making flower-beds in the form of stars or anchors, or human beings, be- 


\section{I T T LE GAR DE N S}

cause the slender points of soil exposed in the outlining of such extravagant devices are easily crossed by grass roots, and by reason of their narrowness are hard to reach with a hoe, except by disturbing the roots of flowers and plants of showy foliage that you may have set out there. If you have been so unwise as to make a star bed with long points in a yard containing witch-grass, you may as well decide to sit up all night with it and keep the grass out. If the people on either side of you, or behind you, have allowed this dreaded vegetable to establish itself on their premises, it will surely crawl under your fence, and the remedy is to spade deeply, vigorously and frequently all around that partition. It is one advantage of a brick wall, such as we seldom use in cities any more, that forbidden growths do not reach beneath it.

Supposing that you have the usual yard, but without walks, so that you are at liberty to lay off your own, you can scheme one to this effect, which, as you observe, is merely a modification of Fig. 2; a compromise, if you like, in that it gives some direct path, and less of the oval. 


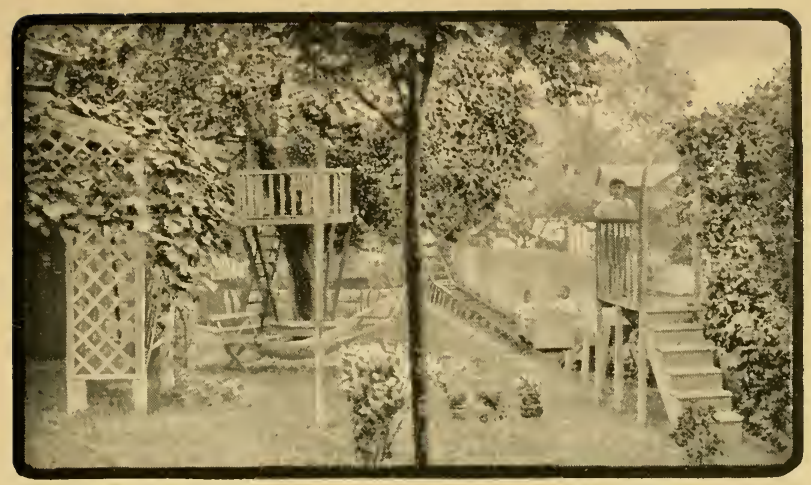

A GARDEN AND SOMETHING MORE.

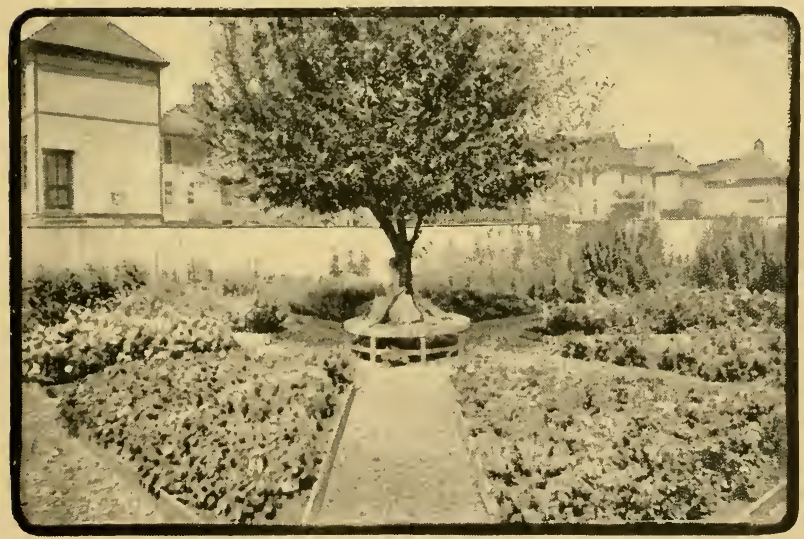

ON THE OUTER EDGE OF A CITY. 



\section{THE CITY YAR D}

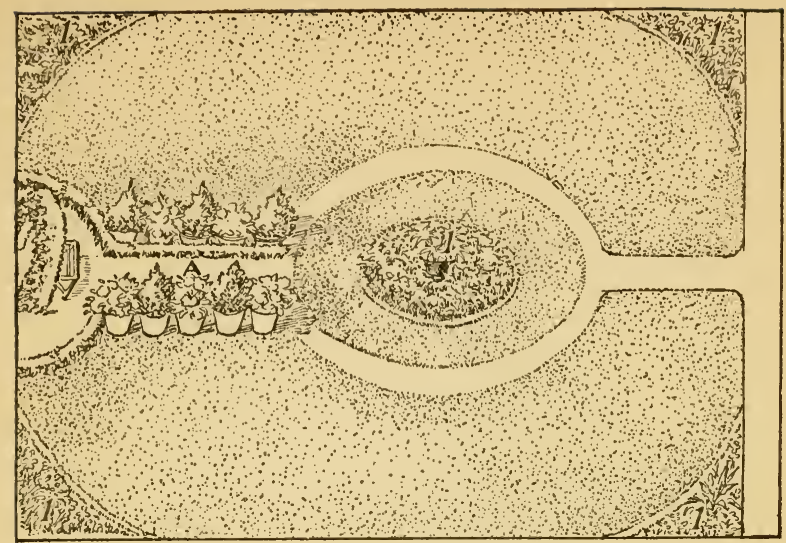

FIG. I 1.-1, Flower-beds.

By lengthening the walk at $A$, in the farther end of the yard, setting box borders on either side of it and placing bay-trees, spruces or tubbed saplings in rows outside the box, a pretty vista will be made that ought, of course, to end importantly, for an avenue of vegetation is a promise: you expect it to lead to something. Therefore, in pursuance of the formality thus expressed, it is fitting to end it with a statue, alcove, arbor, rustic chair or bench. Should a bench be put there, it may gain dignity and the occupants of it can secure shade if it is protected by wire fencing, the same to be covered with climbing 


\section{I T T LE GAR DE N S}

roses or honeysuckle, the arch rising to a height of, say, nine feet.

Still following the formalities, we can go back to straight lines, and use them indirectly in a diamond pattern like this:

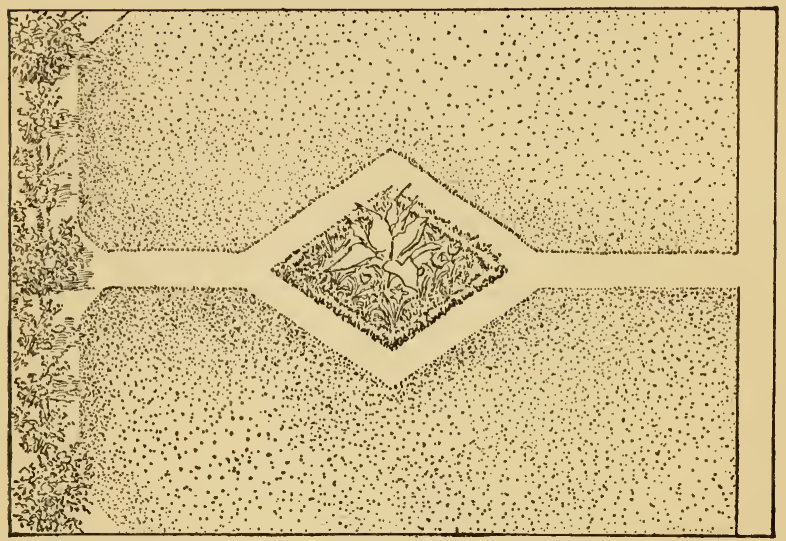

FIG. I 2.

It would be gorgeous, indeed, if you could cover the whole of the diamond with flowers, planting canna in the middle, then gladioli, then dianthus, phlox, love-lies-bleeding, cockscomb and other flowers of red or ruddy hue till the progression ended at the walk in a border of the red alternanthera, or of ruddy coleus. The tri- 


\section{THE CITY YARD}

angular corners marked $\mathrm{B}$ could be filled by tall and bushy plants-nothing better for this than stout old roses. The hindrances to the plan are Mary Ann's feet, for she has so few other places to plant them that flowers must serve; and again we have been a wee bit sparing of grass, unless the neighbors have a deal of it that is in view from our own premises. Also, the divergent walks seem indirect for direct and wakeful people. The floriculture could, therefore, be restricted to a circle in the middle of the diamond. A combination of the last two plans can also be expressed in this:

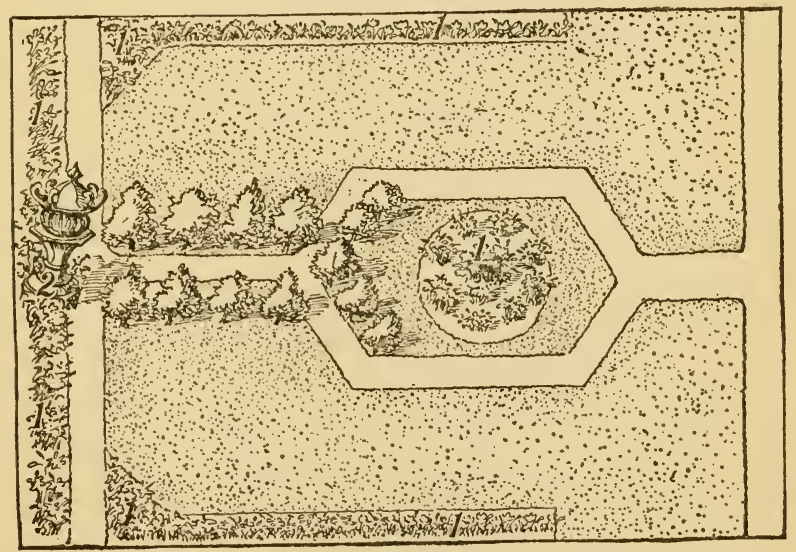

Fig. 1 3.-1, Flower-beds ; 2, statue or lantern. 


\section{I T T LE GAR D E N S}

This, like some of the other gardens, must be laid off by permission of the kitchen powers, for if they decide for clothes, the clothes must have more space and their wearers will accustom themselves to self-denial and hard-boiled shirts.

It will be noted that of the flower-beds thus far, or to be shown, all are of simple form. I am opposed to " carpets," at least in yards, and to pictures and mottoes, and to topiary and all extravagances of artifice. There may, possibly, be occasion for beds in the shape of harps, clocks, flags, houses and lions, but such occasions can not occur in the home garden whereof we treat. In brief, I am opposed to difficulty for its own sake. There may be virtue in the postulate of art for art's sake, and acrobatics for hardship's sake, and Maine laws for the land's sake, but it would be an easier, pleasanter world if we applied our strength to changing things for the better, instead of making things to change, then changing them to what they are now. Simple things are the comprehensible, the agreeable, the permanent, and the universe prefers them. Therefore, let us not be above them in our gardens.

Because of the smallness of space in a yard, 


\section{THE CITY YARD}

it is better not to have it cut up or divided by fences, but a change in level from front to rear may make it compulsory to terrace it, say, across the middle. If it is a sharp change, or if shifting sand makes it hard to bank it, the rise of the terrace can be vertical and faced with masonry-a thing commonly to be avoided in a small space. This retaining wall can be covered with vines or tall plants, save at the center, where a flight of two or three steps could give access to the higher ground. If the economies have to be consulted, these steps will doubtless be driven into the terrace, and will be no wider than necessary; but if the expense can be afforded it is better to have them extend from the terrace in widening crescents-marble against greenery. Should it be possible merely to slope the terrace and cover the slope with turf, instead of holding the upper section in place by stone, the flight of steps will be all the more graceful. Here is the plan.

This assumes that the back of the yard is higher than the house foundation. If the topography is the reverse of this, little change is called for, except to turn the steps the other way and to plant taller shrubs in the distant half of 


\section{LITTLE GARDENS}

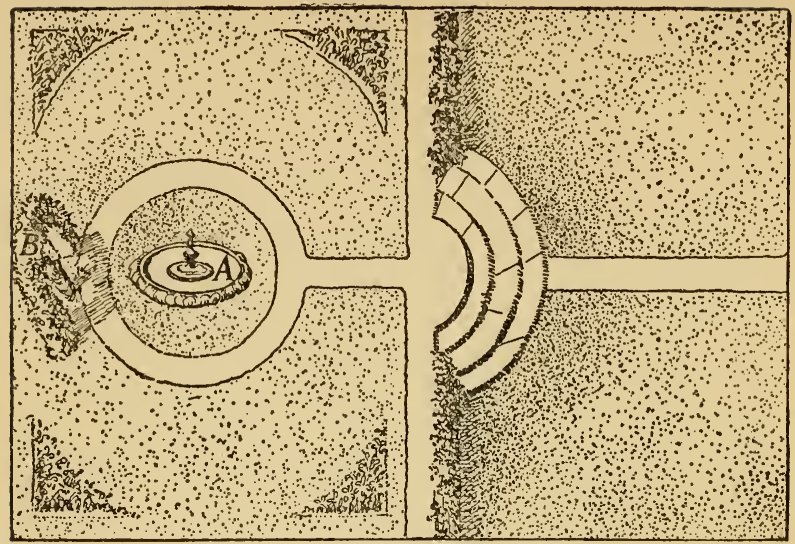

FIG. I 4 .

the yard, that they may be seen more readily from the lower windows. As a terrace pertains to formal gardens, we can use a little more strictness of form here than we might wish to apply to a level, and the upper portion, being pedestaled into a certain adventitious dignity, we can use a fountain at $A$, or a statue under an arch of roses at $B$, with less compunction than if they were just under the clothes-lines.

It sometimes happens that the back of the yard abuts on a lower terrain, in which case you will be constantly losing real estate to your neigh- 


\section{THE CITY YARD}

bor, after a shower. Or, it may be that you have an open fence there, or no fence, or that you are resolved on raising your own lettuce or strawberries. In that case a hedge is excusable, and might be laid off in this form:

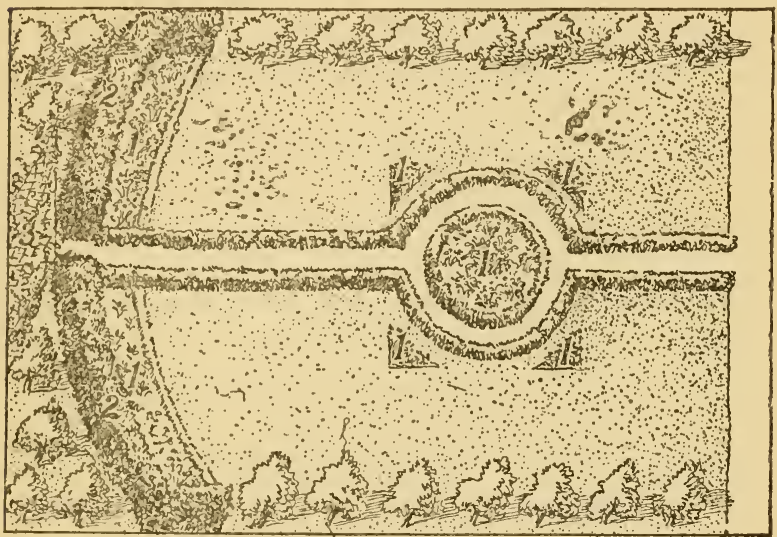

Fig. I 5.-I, Flower-beds; 2, the hedges; 3, the focal point or vista end.

This plan is easily modified; the middle bed can be made square, or diamond shaped, or what not. Its main points are the concealment of space behind the hedges, for vegetables, or, if there is nothing to conceal, it is still a good place for trees. If the ground just behind this area 


\section{I T T LE GARDENS}

is lower, it is wise to plant tough shrubs along the edge of the declivity and plant them thickly, in order to knit the soil together, and prevent little landslides that will eat back into your yard and provide valleys and cañons that you do not want. The curve of the hedges gradually straightens, merging them into a row of bushes on either side of the yard. In harmony with this, it is permissible to border the walk, all the way, with box, a charming accessory of the old-fashioned garden, when well used, for the idea of a border agrees with that of a hedge, and the box, in its compact growth, toughness of stem, and opulent green, is the privet in little. Farthermore, a trellis could be constructed at the back, as shield against an offending prospect and background for a bust, if you want to put one theremy pen came near to writing, "or have one." Horrible thought!

Should this notion of hedging the end of the yard please you so well that you decide to take more room there, to the end that you might have a nook where you could take your sewing or your tea, or where you could read while little Jonas tumbled on the grass, the line of privet could be 


\section{THE CITY YARD}

set forward, straightened, allowed to grow to its full height of twelve feet, the trellis could be carried around three sides of the enclosure, and raised to the same height, and if all that did not protect you from observation and sunshine, a strip of light awning could be extended over a part of the space, attaching its ends to the trellis. Here, in the evening, chairs and tables could be brought, Japanese lanterns could be hung and the family could gossip over the demi-tasse and cigar, while mingling with the fragrance of the Havana would come the odors of the related nicotiana, setting its pale lamps for the lure of moths in the twilight.

Water brings light and life into the dullest landscape, and it has been used pleasantly in gardens, even of the city. I hesitate to commend it in the yard, however, because of the mosquitoes that breed in it. For it is amusing to listen to the talk of draining, burning and oiling the Jersey and Long Island meadows, knowing that the talkers continue to place fire-tanks on their roofs in town, where millions of culex and anopheles get themselves born, and descend into the streets to prey on the multitude. One usually has to be 


\section{I T T LE GAR DEN S}

saving of water in a city. Our towns are growing so large that the supplying of necessities to them is becoming a serious problem. Hence, it is not possible to have reservoirs in a yard where the water shall flow constantly, and so surely as it stagnates, so surely will the mosquito lay her eggs upon it, wigglers will develop, and for the rest of the summer you will visit your garden only in gloves and veils, or under cover of a smudge that will destroy all the sweetness of the flowers. If you do live in one of those rare towns that have water enough, and clear water, and can afford to change it once or twice a day - for it won't do to kill the mosquito larvæ by oiling it, on account of the odor and look of it afterward-it is best to place the pit or tank at the back of the yard. A cement reservoir ten feet across, three feet deep, with a curb raised a foot above the ground is ample, but half of a hogshead, sunk in the earth, will cost much less, though in each case you have to meditate upon the necessity of engaging a plumber. In this aquatic garden you may raise papyrus, lotus, water-hyacinth, and water-lily, and it has one advantage over the flower-bed in that you do 


\section{THE CITY YARD}

not have to cut away the overhanging growths to afford light to it. On the contrary, if your yard were big enough for trees of a drooping habit, the very place for them would be near this pool, where their inverted image paints itself against the reflected pattern of the sky. If it is deemed safe to omit the curbing, all the better, and the installation of the tank makes the fountain easily possible, because it makes some equivalent imperative: that is, you must get water into the tank after you have built it. The flower-beds near the water will be refreshed by the spray, and both beds and pond will gain in charm from one another. If you have such a pond, the water-flowers can be grown there in heavy, porous boxes, sunk at the bottom and filled with loam and compost. And after the water clears it is well to introduce gold and silver fish, not for appearance' sake alone, but because they purify the pond, consuming worms and insects that may fall into it. If, for any reason, fish are undesirable, try, by all means, to persuade some dragon-flies, or devil's darningneedles, to inhabit near. These beautiful creatures, the terror of the ignorant, who believe that 


\section{I T T LE GARDENS}

they will sting and even "sew up people's ears," are absolutely harmless, and they are voracious feeders on the mosquitoes, that will breed in your lake if it is allowed to stagnate. The dragon-flies eat mosquitoes, both in the larval and winged states.

Possibly you are so unfortunate as not merely to be short of water, in which case an aquatic garden is hopeless, but of soil. Your yard may be of sand, or builders' rubbish, in which not even purslain will grow. Well, luckier men have had to contend with harder problems. The mansions on Nob Hill, in San Francisco, are builded on sand that is little more fertile than a plate, or stove-lid, yet by sodding, fertilizing and watering it has been surfaced and is as green as the parks of Eastern cities. This takes time and some money, and circumstances not unconnected with the latter commodity may oblige you to create your garden by degrees. In the first year you may have to consider most of it as walk, raking up the coarser materials and strewing gravel over the paths. Yet, you can doubtless buy three or four loads of good loam; you may even have it of some lot owner for the asking, 


\section{THE CITY YARD}

if you will pay the cartage. In that case a sparing array of beds may presage a larger onesome such device as this:

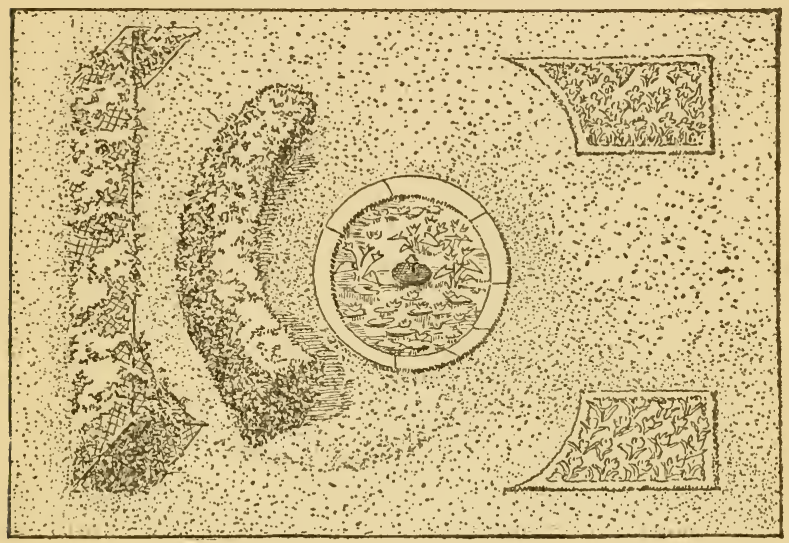

FIG. I6.

Here is another device for a stony yard where the earth has to be imported. The focus, in this case, is at the side.

You can surround each of these little beds with box, so that when you are able to throw on more soil the plan will remain until such time as the yard is covered, and you can undertake planting on a larger scale. A few prefer a frame of box for the floral picture under all circumstances, 


\section{I T T LE G A R D E N S}

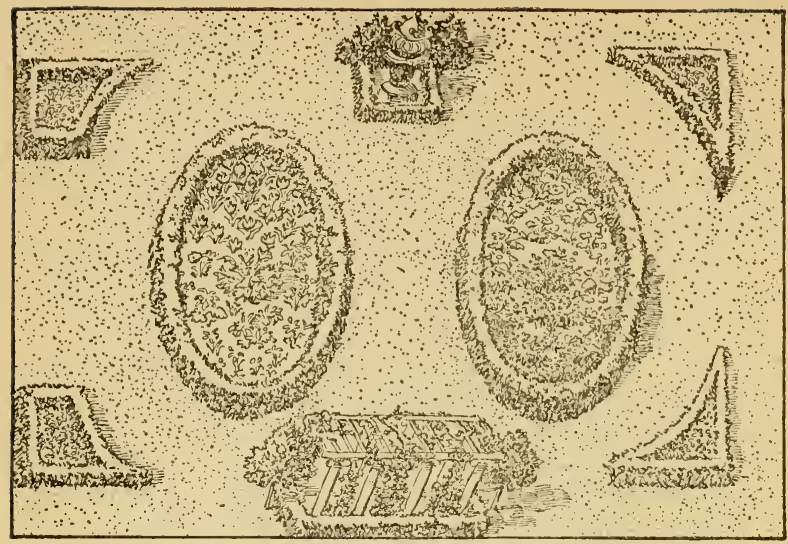

FIG. 17.

and cultivate a close little hedge of it, a foot or more high, about every bed, even such as are devoted to vegetables. Borders are needed when the beds are surrounded by graveled walks, but not when they are merely openings in the grass. They belong to the formal garden, and spaces cut in the lawn are less formal in their aspect. The delicious old gardens at Mount Vernon, that have been growing more beautiful since George Washington cultivated them, illustrate the use of borders. The beds are so sunk in box that they suggest being packed in boxes. They heighten the pleasant primness of a formal gar- 


\section{THE CITY YARD}

den, to be sure, and suggest the tea-cup times of cup and hood, as they are suggested in old family silver, four-posted beds and wax candles. Where formalism is admitted, I own to an enjoyment of hedges and borders that are clipped down to a definite height and show vertical sides. They go with smooth-shaven lawns and flower-beds of geometric outline. But pray stop there. Don't distort your poor cedar, yew, privet; box or Osage orange into a crowing cock, a rampant bear, or an heraldic dragon. Don't deceive yourself into supposing that you commend the tree when you ask your friends to admire it. You are merely requesting praise for your own misplaced cleverness, and one of these days the Society for the Prevention of Cruelty to Trees may hear about you. There may be an occasion for trimming a tree into a cube, a cylinder, a column, a globe, an umbrella, or a cone, though I can't imagine it, and in these shapes we see, reduced to precision, some forms that trees will hint at on their own initiative; but a tree never willingly posed as a likeness of a giraffe, or a gentleman in a cocked hat, or a corkscrew, or a decanter, and it is an outrage on vegetable dignity to ask it. 


\section{I T T L E GA R D E S}

In the square-topped hedge or row, the effect is different. We feel it with the eye as part in a plan of garden architecture, its firm, level lines are restful, it substitutes itself for a wall; hence, it takes its form, it thickens, moreover, with trimming, so as to serve all the better as partition. Topiary, or tree sculpture, is especially ridiculous in small spaces. It is not formalism: it is grotesquery. Have none of it.

In sum, I would say that in the treatment of a city yard be moderately formal-that is, symmetrical-in a formal place; give to trees their natural form, lopping only straggling and obstructive growths; hide the fence with vegetation; group the flowers by sizes and colors; strive for broad, massive effects; avoid the finical and higgledy-piggledy; raise grass; use ornament with frugality and caution, but have a focus of interest, which need not be a geometric center. 


\section{III}

THE COUNTRY YARD

IN the yard of the village house-not the summer villa with its acres, but the country home of country people-there is room for more diversity and opportunity for larger effects than in town, for the yard is moderately sure to be larger than that of a city house. The possibilities of beauty and interest in gardens increase as the squares of their area. Yet I think that the same rules for garden-making hold in the country as in the town, namely, that there should be simplicity instead of extravagance, masses instead of scatterings, law instead of lawlessness in respect of color and form, and that there should be a focus, or point of interest, or constructional center. In the country, however, the point of interest need not be in the ground itself. If your house commands a view of a conspicuous mountain, or an expanse of lake, or a handsome clump of wood, or a prospect of a village with a white 


\section{IT T LE GARDENS}

spire rising above the trees, this can be the focus: the point toward which the lines of your garden will tend. A picture has this dominant note of form, light or color, and its other parts are subordinate to this. If it is otherwise, the effect is confusing, for instead of a balance of light and shade there will be a hundred little lights and shades, each demanding the same attention as the rest. Such a picture tires one after a little while. There is no repose in it. We may not admire a street, for it may be shabby, crowded, discordant in color; but the convergence of its architectural lines toward the vanishing-point reduces it to a certain simplicity, which in itself is dignity, and creates a subtle satisfaction. Far finer are those vistas where the vanishing-point is intercepted by some object of beauty, and where the perspective is marked, not by buildings, but by trees, or hedges, or borders. The view of St. Peter's from some of the Roman gardens, the Pincian, for example, and the view from the Soldiers' Home, at Washington, known as Capitol Vista, both showing aisles and arches of green that end in splendid domes, exemplify this point. 


\section{THE COUNTRY YARD}

Of course, it may easily happen in the country as elsewhere, that the objective point for a garden composition will be lacking. Instead of opening up the paths and alleys on your home ground, it may be desired to lead them nowhere, because they might otherwise carry the eye to a factory, a stable, a stone heap, a dump, a neglected farm, a freight shed or some such unagreeable matter. In a case like that you can do no better than build a hedge and close the view entirely, treating your space thereafter in substantially the same manner as the city yard.

In the country we do not hide our horticulture from the eyes of men, because we do not erect big rows of flats and shops between our gardens and the road. A country house demands a margin. It will have a yard in front, as well as a space at the side or back. Hence it has room for show, to put it vulgarly; for the manner has never obtained with us, and let us pray it never will, of building villages solidly, in blocks, as they do in parts of France and England-a fashion passed down from the time when the peasantry clung for employment and 83 


\section{I T T LE GARDENS}

protection about the foundations of the castle, and when it was cheaper and easier for their lord to tell them off in rows than to build detached shelters for them. Possibly this very cutting off of some of the people from the fields has led them to prize the beauty of the fields the more; and we have to admit that among the British cotters, the garden, simple as they make it, is a source of more care and satisfaction than among many in our country, although the growing of flowers is now general in America. Gardens, if no bigger than bedrooms, are attached to most of the English cottages, and odd makeshifts are often seen in the attempt to force a growth of flowers where Americans would never think of planting them. It is better to cultivate a rood of space as if you meant it than to plant a whole acre and leave it to the weeds and the elements. And in this country, where land is so abundant, and so cheap, we neglect it. We have too many shabby farms and seedy gardens. When an Englishman has a few feet of space, he makes it count for something. In Bridge End, Warwick, a street of old brick-and-timber cottages has permitted no grace and comfort of shade and lawn, 


\section{THE COUNTRY YARD}

every house being separated from its neighbor by a party wall, and plumping itself as full upon the highway as it dares; yet along the front of these dwellings runs the merest strip of soil, curbed away from the walk, and showing, through the summer, a mass of fine, old-fashioned bloom. This communal park, which is, maybe, a foot and a half wide, masks, or rather softens, the quaint buildings, and gives to them a peculiar picturesqueness. The effect would be worth copying if we built and bedded that way, but in America we are doing better: we are taking down our fences and converting wide districts into a continuous garden. The newer parts of the beautiful city of Hartford are a revelation of what may be accomplished by a community that has civic spirit, good taste and good neighborship. On the edge of the town even the trolley posts are half hid in vines, and one of the ugliest incidents of our streets is thus converted to charm.

It is not everywhere that the fence can be abolished. In a visit to a socialist community in Illinois I was puzzled by the number and stoutness of the fences. The disappearing fence 


\section{I T T LE G A R D N S}

in our part of the world means advancing socialism; yet here, in the stronghold of the faith, were the assertions of individual right in property. I asked the reason. "Sure, you don't suppose we could raise anything in our yard," came the answer, "if it wasn't for the fence? The people next door keep hens."

Yet there is little need for fences unless it is where cattle abound. A low wall will keep them out, and the wall can be covered with vines. The hedge is a still better safeguard against cows and tramps, unless it is so savory that the cows eat their way through it; it grows stouter instead of weaker every year; it is handsome and grows handsomer, while the fence grows rickety; the advertising fiend can not misuse it, and it merges the surrounded property into its rural environment. Wire fencing has the merit of unobtrusiveness, but if you expect to go to heaven do not use barbed wire. I am not punning when I say it is barbaric. Let your fence be a hedge, thin and tall, low and chunky, according to your neighbors and your tastes. The Englishman likes his high. He demands privacy. He will erect a stone wall inside his hedge, if need be, 


\section{THE COUNTRY YARD}

and strew broken bottles over the top, that poachers and burglars may cut their blooming fingers off when they try to climb over it. $\mathrm{He}$ will spoil the view from a country road, and spoil his own, by blocking the prospect in this fashion, and will scare the stranger by an exhibit of "No Trespass" signs in his cabbagepatch-signs such as have likewise appeared in our country within the last forty years. The American seldom wants privacy; isolation yet more rarely. Democracy seems to be preparing the way for a closer social compact, in which individualism must suffer. As a token of it we consider privacy so little that we bring the house close to the road, in order to see the wagons pass, whereas it is in better taste and for better comfort, to withdraw it by at least a dozen or a hundred feet. Then you have some beauty and dignity of setting; you do not cheapen yourself by asking the public to look in at your windows, and to listen to the carols of Mary Ann at the tubs. You may also have an avenue before your house, and if you plan this deftly, not only may you lead it toward the road, but make it a vista with some notable passage of scenery at the end-a road 


\section{I T T LE GARDENS}

whereby the spirit shall adventure into new spaces.

In the country, more than in the city, the garden is a part of the establishment. It may be a dozen of geraniums or petunias, or a few sunflowers, struggling toward the sun, but it has an esthetic meaning in itself, and it relates the house to the landscape. A country garden becomes a part of the dwelling of the mind-part of that outlook for which we forsake cities, and that opens to us distances and eternities that towns conceal. You will, therefore, cultivate your garden as if you meant to live with it. It will not be the brief and little solace of a city yard. Its trees, bushes and perennials will bloom in your affection; they will be fixtures, like the weathering porches of your house; like your old horse, your playful hens, your pranksome dog, and your fruitful cow. You will learn to watch for the budding of your annuals in the spring; you will have a calendar of the seasons at your window. You may even learn to forecast the weather from the conduct of your garden and its animal visitors; for they tell us that pimpernel, or shepherd's weather-glass, opens when sunny 


\section{THE COUNTRY YARD}

weather promises overhead, and partly or wholly closes when storms are brewing; at least, the English peasantry believe so. Goatsbeard and marigold also fold together when it darkens, and we have all seen the sleep of oxalis. Countrymen have observed that when the air is clear, when fish dart about, when stagnant water smells, when frogs look dull in color, when swallows fly low, when cobs come out of their webs more freely than in sunlight, then, flowers are apt to shrink from bad weather, and it is time to make things snug. These observations are not my own. I have never seen timidity in flowers, but only regular habits in some of them that incline them to close against too fierce a light, or too dead a darkness. Not only may it be possible to study weather from our yard, but we may know the time of day. At least, it was the dream of Linné-absurdly Latinized as Linnæus (for, suppose we were to speak of our first martyr as Lincolnius!) - to own a floral-lock. This votanist, whose work is held in awe by all who have tried to read it, and in admiration by those who haven't, planned a bed of flowers such as had regular times for opening and closing, so that 


\section{I T T LE. G A R D E N S}

by looking at them he might know the time of day. This is possible. Morning-glories tell us when it is not time to get up, and the evening primrose announces when it is time to play whist and eat. But regardless of these rather strained uses for that which has a higher use than use, you will plant what you can always see and discover promise in it, even when to the eye it is sere and its bare stems give no other voice to the winds than the threnody of winter.

The general treatment of a small village yard will not differ materially from that of a yard in the city, but allowance must be made for the greater exuberance of country bloom. City dust and heat and all-night glare, and the reflection of light and warmth from walls and fences and flagstones, do not tend to vegetal health. The country airs and dews will keep the plants in better trim than you can keep them in the city. Hence it is well to plant them a trifle more widely apart than you would in town, and to provide the supports needed for heavy growth. Be careful not to overload your trellises. I know of one man who uses an old steam-pipe for the stem of his trellis, and it supports a goodly weight of 


\section{THE COUNTRY YARD}

roses. In the roomier yard of the village, trees are also a possibility; hence, the shaping and disposition of the beds will be with reference to keeping their contents out of the shade. Larger flowers, too, can be used in the decorative scheme than can be well employed in the city, for, whereas a row of dahlias might seem disproportionate to a space in town, they would harmonize with the large surroundings of a country place. Then, the accidents of topography give chance for pleasant diversities from custom in the garden plan. For example, if there is a stone-pit, or a ledge, or a boulder at the end of the yard, it can be draped with vines and it becomes an element of the picturesque. Over in the Bronx country, opposite Fort George, New York, there is a villa which has, not behind it, but boldly planted in its front, just as the glacier left it, a sunken boulder which has been treated in this manner, and it is worth a good deal more, as a scenic feature, than much of the smugness to be found elsewhere. Again, it may be that a brook or little river will cross your property, and it can be shallowed and widened into a bay where you may plant water-lilies; or, if there is a boggy 


\section{I T T LE GARDENS}

spot, and you are sure that mosquitoes are not breeding there, it can be utilized for plants like flags, marshmallow, marsh-marigold and forgetme-not.

It is wiser that these incidents should be intimate and domestic than to attempt grandiose or park-like effects. Indeed, even our parkmakers, our landscape architects, as they are called, are conceding much to the taste for simplicity. Frederick Law Olmsted, who wrought a needed reform in this respect, aimed to preserve the natural landscape, merely softening it to human uses; to teach, and to satisfy men with the qualities of gentleness and loveliness; to remove from sight all harsh, discordant elements, and to stimulate pleasures in the air, which yield health and content, and calm the fever of social life. In the park, private as well as public, he strove to conceal his art and pleasantly to deceive the wayfarer into the notion that it was all nature in a holiday humor. We must regard our ground as a part of the home, and govern its use and ornament accordingly. In town nature has been humanized out of likeness to itself, hence, artifice in gardening conforms, not merely in aspect, 


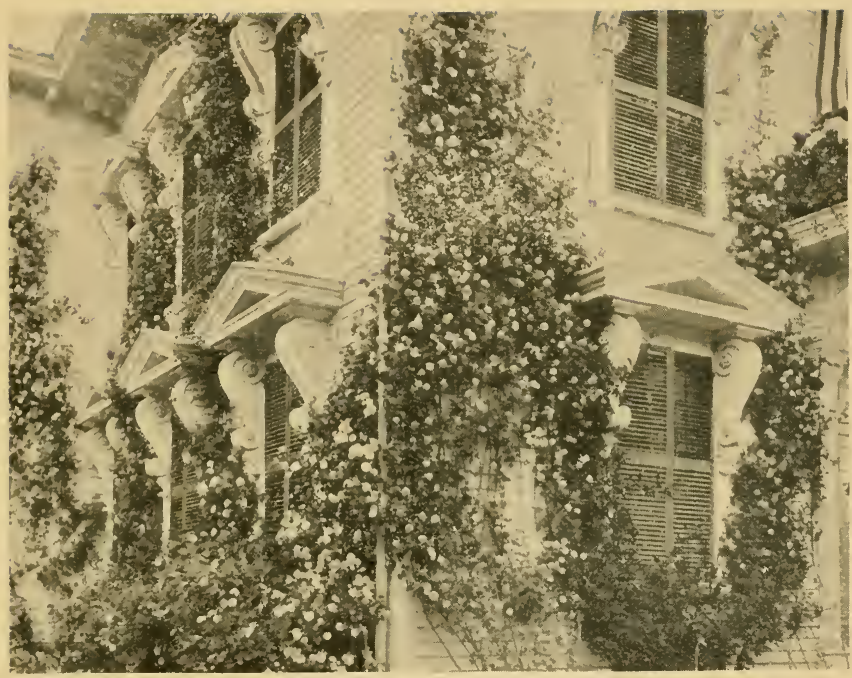

ROSES IN PROFLSION. 



\section{THE COUNTRY YARD}

but in spirit, to its setting. We may, indeed, give it as an axiom, that the more formal the house, the more formal the garden. In the suburb, or the village, we meet nature half-way, and our yard is not an uncovered greenhouse, but rather a link between the joy of home and the lawlessness of the wild. A village garden can be charming if it draws only on the fields within sight of the house for its materials, and it becomes esthetically and morally useful if it teaches to the villagers the immanence of that beauty which, too often in their conceit, is a far and merchantable quantity. The city yard is an entity. The country yard is foreground for the large and affecting beauty of the hills.

As to trees, it is possible to have too many of them, and too close to the house. Modern landscape architects will not hear your pleading for just one elm before the house, or just a couple of maples at the curb-that is, some of them won't. Sunshine in the house is the first desideratum, and that is proper. Spirits and sanitation both require it. Yet I do not give up the idea of trees on the premises. They should be massed, like the flowers, in groups or pairs of the 


\section{I T T LE GARDENS}

same variety, not scattered. A field with twenty trees will be spotty and complex if they are isolated, but if arranged in a cluster, or in lines that edge the property, there are seemingly more trees, and certainly more lawn. One big space is worth twenty little spaces. Nor should trees be permitted to close a vista. Rather, they should form a part of it. In forbidding trees to the lawn I mean that they are not to be dotted over it, but that does not prohibit us from using small and graceful trees like the Japanese maple, or weeping birch, or smoke tree, or a lilac, as part of a group in a composition. Be frugal of trees immediately at your doors, at least, if they threaten the light and air in your rooms. I am going to violate the law, myself, by having a pine-tree at the corner, when I acquire the right sort of corner. No other tree means so much in its speech, or baffles the listener more piquantly. Its mystery is its charm. In its sighing and whispering you hear the voices of the sea, the murmur of solitary streams, the questioning of released spirits, the stirring of distant hosts. Its voice is large and cool, and it goes with the flash of stars on January nights and the peal of the 


\section{THE COUNTRY YARD}

wind when the sun begins to fall to the south. Like the other occupants of the home ground, it does not satisfy the eye alone; it addresses the mind and imagination.

Perhaps you are frugal, or sociable, and prefer fruit-trees to pines. Better see that your neighbors are supplied with the like, then. I once had a pear-tree and a raspberry patch in a town yard. They were a harrowing experience. Some one had to run out every hour or so, and shoo the boys away-not that we cared about the pears, much, because they were of a variety I have never found anywhere else, being as hard as cocoanuts and as digestible as rocks; indeed, the rogue who stole one deserved to eat it; but the little rascals broke the limbs, impaired the symmetry of the tree, and the premises, trampled the flowers and made the grass as sadly in need of combing as their own heads. I had a notion to put up Charles Dudley Warner's "Children, beware: There is protoplasm here!" But that would have brought them in to look for it. I might have strung an electrified wire about the yard, but the boys who had enjoyed an experience with it would then have led in shoals of 


\section{I T T LE GAR D E N S}

other boys, who had not heard that the wire was loaded, in order to initiate them. You suffer from parasites, no matter what you growparasites in the forms of insects, weeds and boys. You can kill the weeds and insects.

It is by the judicious use of trees that barns, stables, henneries and other structures that were anciently a sorrow to the eye, however much of a pride to the understanding, are concealed from observation, yet the tendency is to put up a barn so much larger than the home, and so much handsomer than the places in which many of the builders were born, that if I were they I would not screen these architectural triumphs by so much as a pea-vine. Where the outbuildings are not a source of pride, however, it is well to thicken the vegetation between them and the house. Perhaps in any case the stable is the better for a hedge about it, for while the upper part of that building may satisfy all demands of an esthetic nature, the lower portions are commonly stained with reminders of earthiness, and green is pleasanter. Beside, apart from the purpose which a hedge will serve in this concealment, its repetition of the long, flat lines of lawn, 


\section{THE COUNTRY YARD}

walk and other appointments is restful. Horizontal lines in a picture or a landscape give a sense of space, yet of repose, while upright lines are excitant-the precipices of Yosemite, for extreme examples. Still, it is more from conditions than from forms that we derive tranquility. There are moods, to be sure, in which one becomes impervious to disturbing suggestions of the city, when we are in the thick of it; when the sun pours serenity from the sky, and the hardness that so often assails our ears and eyes passes out of a world that has ceased to be substance and has become aspect. Our grounds comfort us by the induction of these moods. In them we find the interest and rest which differentiate the home from other parts of earth.

The ground of a country place should have a seeming tranquility, signifying that it is a refuge from the storms of life: hence, in laying it off there should be no building up or digging down, without a better reason than precedent. It is a practise in some suburban settlements to place the house on an artificial knoll or terrace two or three feet high. This, I dare say, is a survival of the custom of banking a house with earth, on the 


\section{I T T L E G A D ENS}

setting in of winter, though if we see the lifted house in a low, flat country it doubtless means that the soil is so muddy or so subject to overflow that the residence has to be raised on a manner of stilts, for dryness' sake. This perching of a house on a knoll of such trifling elevation adds nothing to its dignity. It is otherwise with the early nineteenth-century mansions of New England that stand on natural elevations either near the road or at a few rods back from it. As a rule, the farther from a road, say, to a distance of five hundred feet, the more the aspect of importance that a house takes on; but there are many fine old homes in eastern Massachusetts that remain on terraces, left by the lowering of the highway grade before them. Usually the terrace front consists of masonry, and noble elms and maples frame the entrance. There is a sense of leisure and refinement in these old manses. A house that comes flatly to the roadside confesses, in that fact, either that its owner spends much of his time running for trains, hence, he can not spare a moment to cross a garden, or that he is so devoid of self-resource as to occupy himself at the windows, gaping at the pedes- 


\section{THE COUNTRY YARD}

trians and teams, when he might be studying sociology, taking naps or practising on the flute. The modern idea is to "get there." So we go by the straightest paths and ask for short cuts, even in our learning. But I admire the reserve, the personality, the implied resource of a house, say, like Longfellow's. Standing thus apart, refusing itself as a unit in an architectural sum, or a social division in a block, it requires trees. They are needed at the curb to shade pedestrians and extend coolness, while they have the effect of sheltering the roof and adding to its privacy, if they are close enough to show above it. In such an instance there is room and even need for a garden in front, especially if the dwelling is colonial in period or in style, for the colonial is formal, while cottages and the usual farmhouses are not. If there are flower-beds before it, possibly the resident may have no care for others in the roomier precincts behind it, yet that is where they show to the best advantage. When a house stands broadside to the road, as is the way in sundry of these old estates, it implies a wider garden than we find in the city where the dwellings squeeze up against the walk and dig 


\section{I T T LE GAR DEN S}

their neighbors in the ribs with their elbows. A broad house is pleasanter to view from its garden than a narrow one, and if only because of its amplitude, needs more of ornamental treatment. This it has from Gothic enrichments in the old English halls, and on the Continent it is beginning to take on outside decorations, often painted on gables and blank spaces. Because a large structure fills the eye more nearly, it causes the more discontent if it is ugly. If the garden has area enough, the house is seen at landscape distance, and becomes important as a part of the picture; hence we can devise vistas with the house itself at one end, and a passage of agreeable scenery at the other. These effects, calling for landscape-gardening on a large scale, are hardly to be considered in a book on small grounds. They require at least an acre. The view, however, may be as free to the occupant of a hovel as to the owner of a Biltmore, and where it is present it serves for laying out the guide-lines of a garden composition. Here is a plan, carried into effect in a country place near Philadelphia. The view is supposed to be toward the rear. 


\section{THE COUNTRY YARD}

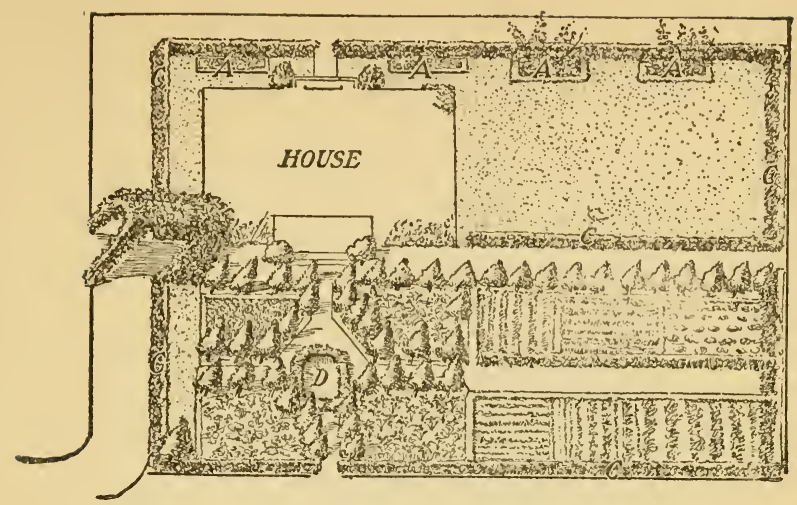

Fig. I 8.- $A$, Flower-beds; $B$, vines; $C$, hedges; $D$, pool, surrounded by coleus and plants with ornamental leaves.

The back of the house is draped with vines, and tubbed yews and cedars are placed along the borders of the walk. The drive, by which carriages may enter the premises from the high road toward a barn, which is rather distant and is not shown here, is spanned by an arched trellis covered with vines, so that a visitor is inducted at once into the garden, unless he enters by the front door. Hedges enclose the whole area and also partition the lawn from the kitchen-garden, so that the vegetables are not in view from the front, although there need be no timidity as to exhibiting these in the country. 


\section{I T T LE GARDENS}

A place in New Jersey has a broad walk leading from the house toward a lovely wooded and watered valley, this walk containing a chain of flower-beds in the center, a border of lawn on either side, with close-set cedars along their boundaries, and hedges dividing the lawns from the walk.

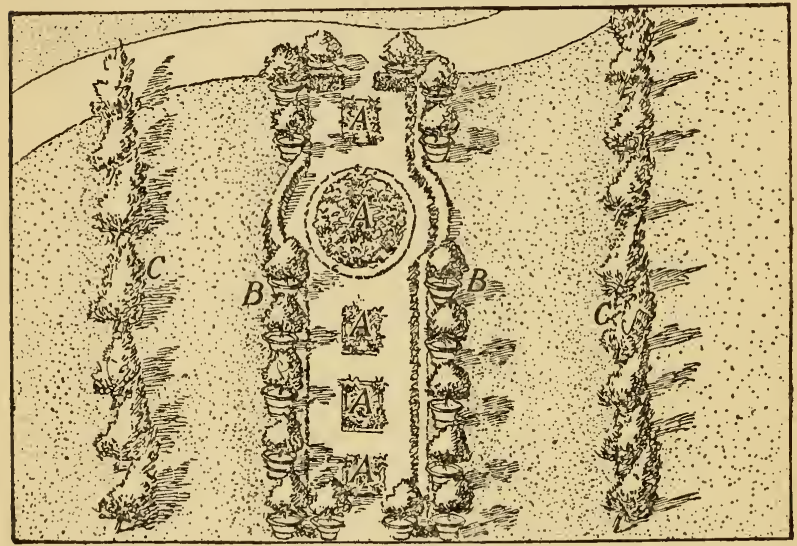

Fig. 1 9. $-A$, Flower-beds ; $B$, potted cedars ; $C$, planted evergreens.

In this case the lawns and walk create the impression of a long reach toward the distance, and they incorporate the scene into the grounds, the more readily as a downward slope at the lower part of the yard conceals the end of the 


\section{THE COUNTRY YARD}

path, where it opens on the high road, so that the imagination travels farther over it than feet can do.

For the more usual space in a suburb or a country village, a space of seventy by a hundred, or thereabout, which allows room for the detachment of the house, the next plan is submitted. It divides the territory with a fair degree of economy, and insures a lawn, a formal garden, several flower-beds, a few thickets, a place for drying clothes, a kitchen-garden, a grape-arbor, with hedges about the property and also dividing the utilities at the back from the grounds reserved for pleasure and ornament at the front. In case the tract is more extensive, so that the barn and vegetable patch may be retired to a greater distance, they may be obscured by clusters of low-growing trees, with, perhaps, a single tall one to break their possible monotony. Trees so assembled should not be trimmed or lopped, except of dead or unsightly limbs; indeed, trees that do not close a view are generally to be left to their own devices. This scheme assumes that the pleasanter prospect from the house opens toward the right, across the formal garden, and 


\section{I T T LE GARDENS}

the broad walk extending from the front door through that reservation gives reach and foreground to it. When the view is distant and commanding, the forespace should be kept as clear as possible, and the house and gardens should take on all the aspect of beauty and endurance that can be afforded. When it is near and romantic-a dell, a cascade, a river passage-it can be framed in vegetation and the avenue can be narrower.

If the shape and size of the ground are much as they appear in the last plan, but the shed or barn in the corner opens toward the road, so that

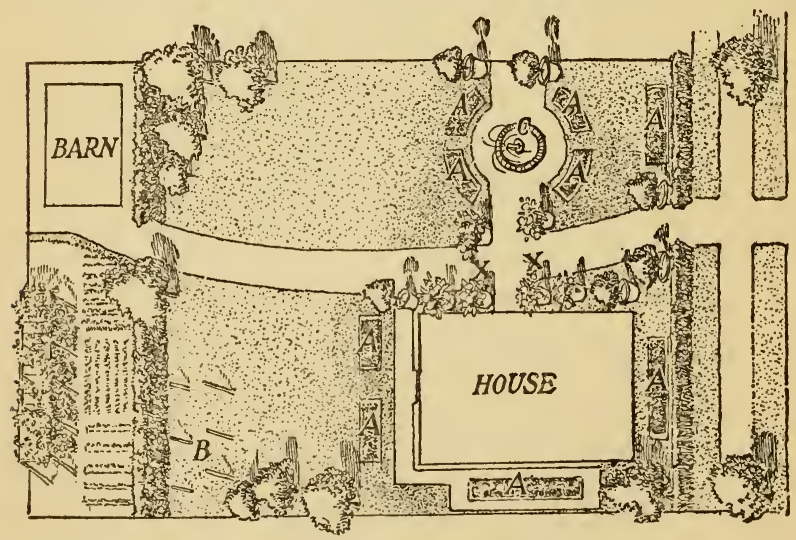

Fig. 20.- $A$, Flower-beds; $B$, place for drying clothes; $C$, fountain, pool, or statue; $X$, hydrangeas or tubbed trees. 


\section{THE COUNTRY YARD}

a direct drive is better liked, the outlines may be altered to something in this fashion:

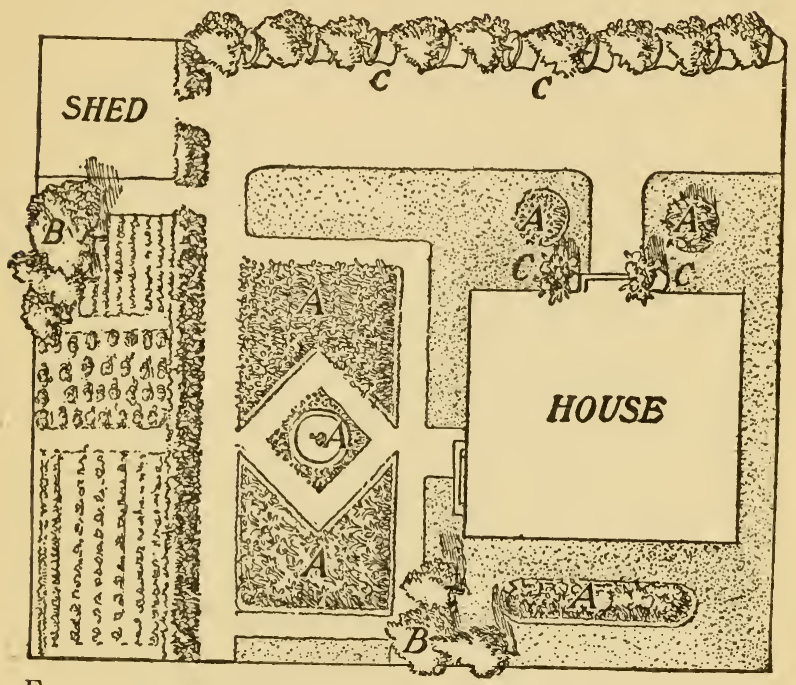

FIG. 21.- $A$, Flower-beds; $B$, trees; $C$, trees or large shrub in pots.

In this scheme the stretch of lawn immediately behind the house serves for the drying of clothes; or, if the house is somewhat aloof from a settlement, or the residents are indifferent to observation, the grassy reach at the side, occupied by the long flower-bed with rounded ends, can be appropriated for that purpose. If the 


\section{I T T L E G A R D E N S}

driveway from the road to the barn or shed is muddy or otherwise unpleasant, it can be largely concealed from the view of the house-dwellers by running a hedge along its inner side, opposite the slender strip of green on which potted shrubs have been placed, or large and hardy bushes planted. A hedge is set along the rear of the premises, not to close the view of the "truck patch " merely, but to afford a background for the formal garden, the interest of which can be heightened if the circle in its center is a little pool or fountain.

Some of the trees on the premises ought to be evergreens. You are grateful for them in winter. A little grove of firs and some rock work can diversify a far corner, or both of the remoter corners, in case you have no "truck patch," and no barn. And these evergreens need not be pines, hemlocks, spruces, cedars, yews, balsams and the like; they can include the rhododendron, andromeda, wintergreen, myrtle, and other shrubs that stay bright till after Christmas. The variety of smilax known as cat brier scratches and makes a tangle, but it is a bit of winter color that serves as well as holly for a Christmas deco- 


\section{THE COUNTRY YARD}

ration. Holly and other berry-bearing bushes are to be prized also, for their fruit is as brilliant as flowers at a time when nature carries her softest yet most brilliant effects away from the earth and paints them over the sky. There are fashions in trees, as there are in shirt-waists and parasols, and a present tendency is toward low-growing species, of "weeping" habit, though willows are no longer elected. "Weepin' willers" environ some New England mansions still, and in central New York a few avenues of poplars remain before the abodes of "elegance" -Lombardy poplars, "the proper tree, let them say what they will, to surround a gentleman's mansion," as an old writer observes. Tubbed trees of dark and solid green, privet, spruce, the West Indian bay, palms and rubberplants are always useful, and in a small yard they can surround a floral square or circle. One fashion of dealing with them is to make a gravel ring about a flower-bed, place the tubs upon this ring, and plant a border of foliage plants still outside of them, to conceal the lower part of the tubs, as in Fig. 22.

If the long dimension of the house fronts on 


\section{ITTLE GARDENS}

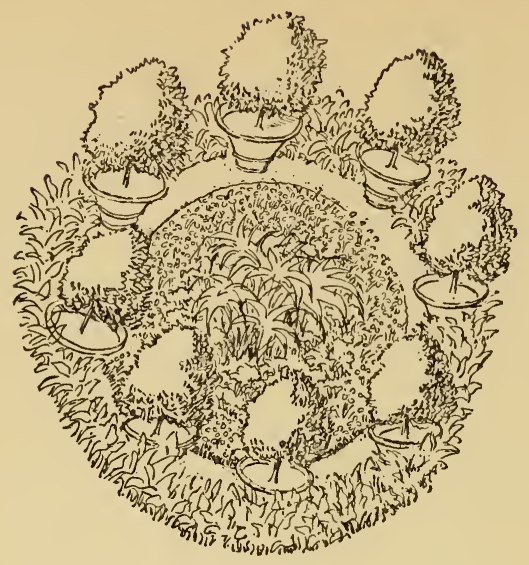

FIG. 22.

the street and wholly fills the width of the lot the yard at the back will repeat its shape. In such a case the yard might have an ornamental center with subcenters at each end.

Of late we have seen an extension of Spanish mission architecture, a simple, and in some parts of the land appropriate style, not merely for churches, but for residences, and Orange, N. J., has chosen it for a jail, determined that her rogues shall go through the form of going to church. If a home built in this manner is large, and parked about, it makes as pleasant and almost as picturesque an object as those Doric tem- 


\section{THE COUNTRY YARD}

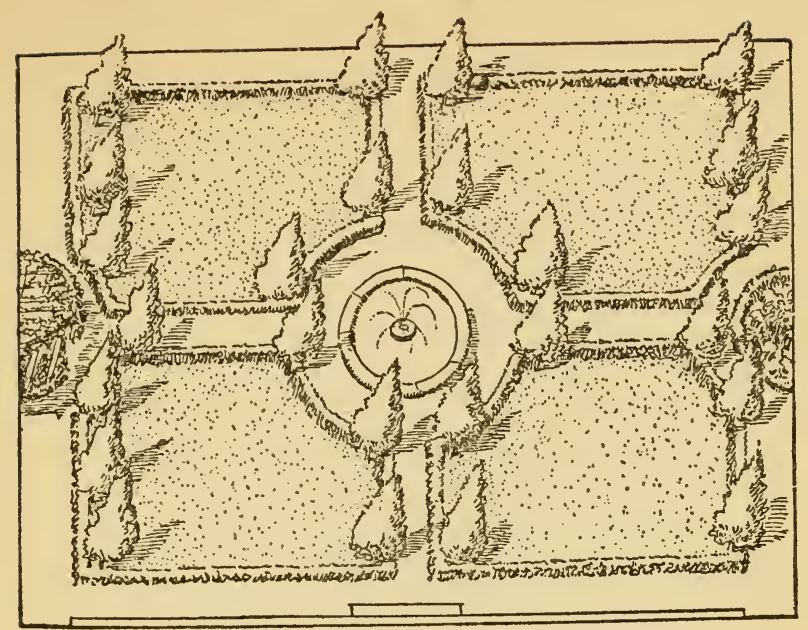

FIG. 23.

ples we used to live in, back in 1820 , and the early English castles-of granite, sometimes, and stucco at others-that were popular among the rich in 1850 . The mission style really needs room, just as does the Greek and the Gothic. Still, in the Southwest, where they continue to use adobe, and agreeably follow the Spanish traditions in their building, a mission residence would not seem affected or out of place on an ordinary suburban lot; and a yard given to grass, with a well, fountain or pool in the center, and an oblong or oval walk about it, is a delightful 


\section{I T T LE GAR DENS}

reminder of the monastic gardens of California and Mexico, and is possible where it is still the custom to draw water from a well, or where the water rises close to the ground level in a spring. If a well, it requires a high curb, lest the frequenters fall in; but if a basin, then a low curb, or no curb, would be permitted. I have seen such an arrangement, with the surrounding walk bordered with box, a safeguard that prevented the ramblers from stepping off upon the grass, as it might otherwise have pleased them to do. Naturally such borders seem disproportionately large, and if they are suffered to attain to any considerable height they shut off the view from the walker in his own garden. Yet an alley of shade offers a pleasant vista in itself, and will have an air of cloistral seclusion that is pleasant to quiet souls; for, as they take the air at evening they will realize that they are not exhibiting before possible spectators. A pool or fountain not being feasible, it preserves something of an oldfashioned aspect for the place if the substitute is made of a sun-dial, with a narrow rim of flowers about the pedestal, or a small vine clambering up the standard. 


\section{THE COUNTRY YARD}

Arbors are to be viewed askant, unless at a remove from the house. They contribute to a crowded and top-heavy effect, unless there are individual reasons for them, such as the outdoor tea habit or a fondness for reading in the shade; but it would suit with a Spanish mission walk if the farther reach of it were roofed by a pergola, slight and simple as possible in construction, and covered with climbing roses and honeysucklethough the latter is so dense in its mode of growth that it shuts off air and light, even in winter, unless it is often trimmed-and opening on the yard in little arches or square windows. Such a walk would be for lonely contemplation, and would be for a poet, or an Englishman.

And if an Englishman, and he really wishes seclusion-otherwise he is an American-and he is the owner of the property, he can substitute for the cheap, ugly, unlasting fence, which still survives in the village, a brick wall which will give a support to his vines and a shield to all his garden from the winds. They are not a lasting joy to contemplate-bricks aren't-especially in seasons when the leaves are off, but it is possible to mitigate the plainness of a wall of them by insets 


\section{I T T LE GARDENS}

of terra-cotta panels or borders, such as are cheaply offered in these times, and wear nearly as well as brick itself. Should a garden be surrounded by a brick wall a large panel in terra cotta could be built into the center at the back, or a seat could be built out from it. The sculptor Pepys Cockerell has recently finished a curious work at Lythe Hall, an estate in Haslemere, England, which consists in a frieze representing a hunt, chiseled from the solid brick of a wall which is farther ornamented by a coping above and buttresses below, and which is surfaced with ivy to the base of the frieze. Were I doomed to live always in a city, I would have the view from the garden no less attractive than the view into it, and I would therefore try to give some dignity to the rear of the house by placing on it a large design in terra cotta, or even in color, and some beauty, by growth of vine and an exhibit of window-boxes. The architectural scheme of the house should be carried into the stone or brick wall enclosing the garden, and-but I must wait till the ship comes home. 


\section{IV}

COLOR

TAKING us as a people, by and large, our enjoyment of color is rather barbaric. We have no objection to a lot of it, and if the key is high pitched it does not keep us awake. We have held puritanical objections to liveliness, whether of color, music, speech, thought or conduct, but either we did not recognize it in tints when we saw it, or we are recovering somewhat of that youth of the eye that it had before Cromwell blacked it for us. We improve in taste as we grow younger, and the hope that penetrates far into the future sees, even in our streets, such splendors as were seen in Florence in its days of greatness. Flowers can be vehement, though they seldom are, for green is a delicious solvent that brings them into relation, and often into harmony : and, again, they are of a purity and transparency that softens them, even in contrast. If the hues of certain blossoms are a bit aggressive 


\section{I T T LE GARDENS}

in the sun, we are to remember that we seldom see them in full light, and that the shadows of leaves, tree trunks and walls do much to tone down what else would be too shrill. Then, it is more severe upon us to turn a single ray of sharp red or yellow upon the optic nerve than to flood it with the same color. We resent little effects; we want broad spaces and masses; hence, it is not well to have a quantity of unrelated tints in your garden. A solid bank of marigolds, azaleas, or what not, is a comfort in its mere aspect; we bask in it, and seem to appropriate from its color some delicate material for the building of the spirit, even as physicians have discovered varying pathological values in reds, blues, greens, yellows, browns, grays and blacks-excitants and sedatives.

In flowers we have every primary and secondary color, and many shades of each. May I be pardoned if I revert briefly to first principles. Light can be broken into three primary hues: red, yellow and blue. Mix any two of these and you have a secondary.

Where red overlaps yellow, it makes orange; where it overlaps blue, it makes purple; where 


\section{O L O R}

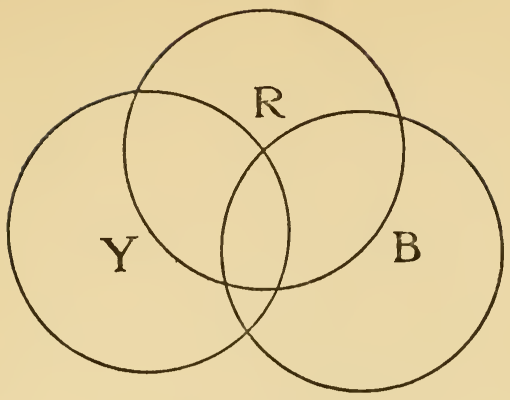

FIG. 24.

yellow and blue are blended, the result is green. In these six we have the rainbow, if you add that deeper blue we call indigo, on its outer rim, and that strange liver color which fills the space between the two arches when there is a double bow. No color is black. Where all colors blend we have the pure white light-if we use the spectrum, because if you mix pigments that way you have only a mess. IVe paint the earth when we plant flowers, but a charm of these little friends is the tender and ethereal quality of their color. A certain red in paint is thick and dull, but on the petal of a rose, peony or rhododendron it gleams like a jewel.

Nature does not enjoy a reckless mixing of tints. She softens her distances by toning them 


\section{I T T LE GARDENS}

to blue, in harmony with the sky and sea; her universal green is the most restful and satisfying of all hues: with what splendid sweeps of her brush of sun-rays does she change our woods in autumn, and what lovely purples and violets we have when the blue of a few miles of air blends with the red of the oaks and maples! Our garden will be more rich if we treat it as the artist treats his canvas, and avoid harsh contrasts and tiny dabs of color. Sow yellow with a generous hand, and the earth will smile its content. Unless, to be sure, you are one of those who have an aversion to it, in which case, take another color. For myself, I find beauty in any tint, but I ask that it be used purely and be kept from jangling with every other. And the way to use it, is to use it largely and simply. The limits of a garden are so small that you may think you are forced to plant primaries side by side, and find that they jar a little. If you interpose a touch of that with which you want a color to harmonize the thing is done. For instance, you have a bed of red nasturtiums, and you wish to put some yellow flowers in the center or about the borders. Then use orange nasturtiums as 


\section{O L O R}

blenders, for they contain both yellow and red. So long as you keep to one kind of flower you are in little danger from discords, because here again nature attests her esthetics and gives warrant for our own. For it is a well-known fact in botany that the flowers of any plant species will be restricted in their coloring to two of the primaries with, probably, the intermediate tint, that comes of hybridizing. For example, the rose rejects blue and keeps to red and yellow. It also adds white, for that does not commit the plant which elects it to the use of the third primary. The rose has almost every shade of red and pink; it has a gamut of yellows; it even threatens to blend these and produce an orange rose, but has gone no closer than a salmon tint, so far; but you will find no rose with a purple cast, for that would promise a divergence into the third and forbidden primary-blue. We shall probably never have a blue rose; at least, the labor of experts and centuries in the endeavor to produce one has come to naught. We should not care as much for it as for the rose of to-day if we had it, I dare say; at least, after the novelty had worn off. 


\section{I T T LE GARDENS}

Taking another family, we find the same rule proved: the chrysanthemum is yellow, red and white, with blended hues, but never blue. In the aster, which it resembles, we have, on the contrary, no yellow, but red, blue and white, commonly the red tinged with blue and the blue showing a trace of red. In the sweet pea we have blue and red but faint yellow; in the azalea, red and yellow, but no blue; the canna and gladiolus exhibit various shades of red and yellow, but no blue; in the cineraria we have a lively exhibit of ruddy blues, but never a touch of yellow; the geranium has several shades of red, with a scarlet that indicates an admixture of yellow, but there is no geranium which sows a hint of blue; the bellis copies the color range of the aster, hence it is not yellow. There are a few exceptions; for instance, we have red, yellow and blue in the columbines; and the violet is both yellow and purple, the latter a mixture of red and blue; but these exceptions are just enough to prove the rule.

If, however, we put flowers of unrelated families into close touch with one another we may perpetrate an inharmony now and then. 


\section{O L O R}

Some boldly throw complementary colors together. A complementary, or opposite, is that color which is not contained in the complemented. Thus, red is the opposite, or complementary, of green, a compound of the two other primaries, and vice versa. If we look intently on yellow, then quickly turn away, or close our eyes, we shall see purple, that color representing the combination of those other two primaries which yellow is not; if we look away from blue, we shall be conscious of orange. Some ingenious pictures were published a few years ago called "Ghosts." One looked for half a minute steadily at a green rose with red leaves, and turning his head smartly looked into some shadowed corner, where after a few seconds, a phantom rose, of normal color, duplicating the form that he had impressed upon his eye, appeared, sometimes with surprising clearness. In the same way, the picture of a sheeted figure in black became a ghost in white when the observer looked away from the plate, and off into a darkened room, while a figure in white repeated itself in black against a white wall. These experiments account for a good many supernatural appearances, 


\section{I T T LE GA R D E N S}

and are of physiological interest no less. But what the eye does as by mechanism is not of necessity a guide to that which we shall do with our hands. Complementaries when crudely juxtaposed, yellow with purple, and orange with blue, are apt to get to quarreling with one another when our backs are turned. Veiled and softened by air and shadow, nature's primaries, whether used with opposites or not, seldom clash disturbingly, but close at hand, in our home plot, it is better to harmonize than to contrast. The cooler and quieter colors fit themselves more easily to a miscellaneous company than do the gayer ones; indeed, we can make one rule suffice: to keep cool and warm colors apart, each in the society of its like. The scarlet of geraniums is acid, but it is less endurable when supported by a sharp, high green of the same "value," than when offset by a darker green. Put a glaring scarlet geranium alongside a bright blue flower of any sort, and there is liable to be a riot. Scarlet geraniums are rather intractable things, yet apparently the most popular of pot-plants. They are effective in borders and masses, but those of a rich China red, and of pink and white, are more 


\section{O L O R}

agreeable and more generally useful. Complementaries make one another more intense. If we put the yellowish leaf of a nasturtium against the magenta of a cineraria, the former becomes more brilliant, and the latter more rich and solemn. But if we put a crimson rose beside the cineraria, and maybe, place a bunch of purple grapes before them, we should have three related colors and a harmony, eliminating, of course, the nasturtium leaf. If, on the contrary, we were to put the cineraria into a combination with a ripe orange and a bit of cloth of a bright blue-green-secondaries, all-we should have three semitones of a major chord, and semitones make discord when they are not separated. Flowers that have a tinge of blue, or red or yellow in common may be used safely. If it is, for any reason, necessary to bring colors near one another that are addicted to quarreling, use as pale tints of them as possible, because white is a wonderful quieter and sweetener, and separate them by green, or some medium tint, if they can be kept a little apart. Almost any color justifies itself when it is exuberant in quantity, yet the finer and softer tones of it win us, in the end. 


\section{I T T L E G A R D E N S}

When in doubt, use white. That is safe with all colors. It does not make a harmony with them, any more than green makes harmony. We are to regard it rather as light. We can enjoy the effect of marble statuary, balustrades, urns, columns, stairs, curbs and walks in formal gardens, and the white of this stone grows the softer, yet the surer, for a backing or surrounding of somber yews and rhododendrons. It is pure and passionless and seems always to express engaging innocence, whether we find it in the rose, the hyacinth, the locust or the water-lily. I wish we were not so frightened by the possibility of it in our costumes, and did not confine it to varnished shirts, tin collars and boiler-plate cuffs. Every one looks well and younger in white, and nobody looks well in black. So, in flowers, white may not dazzle or surprise; it does not gratify the barbaric fondness for show; it is not sensational; but it is always welcome, always comforting; no less than green it expresses serenity and health. 


\section{V}

FLOWERS IN THEIR SEASON

THE main thing in our garden-making, is not the shape of the beds, nor even the arrangement of what is put into them : it is the plants and flowers we grow there, not forgetting the grass. And in respect of flowers, one has a wide and delightful choice. There is an almost irresistible temptation, on the part of beginners in yard gardening, to overdo the matter and to put more plants into the ground than the ground will feed, and more than suffices for appearance. The canny seedsmen understand this willingness to be tempted; they feed it and reap an exceeding great reward. They realize that every catalogue they publish, with its gaudy colored plates of cannas, such as never grew for any human coaxing, and verbenas that stand up with military consequence, putting up massive heads of gorgeous blues and crimsons, instead of straggling helplessly over the bed, looking for a place to lie 


\section{I T T LE GAR DENS}

down and go to seed, and of cosmos that springs to a six-foot measure in a couple of nights and flaunts around the premises in clouds of pink and red and white-they realize that the man who receives these eternal blazons will brood over them, in a state of increasing helplessness, falling deeper and deeper into the toils of his own and the seedsmen's imagination as he does so, until, wholly victim, he opens his desk and composes a check, in return for which he receives certain envelopes of seed, and sundry unpromising fragments of root or cuttings and various withered bulbs, all of which may, yet now and then, do not, explode into floral fireworks a few weeks later. Commercialism is a dreadful thing, and when flowers get into it they do not appear to exercise any more restraint on the moral habits of their growers than if they were pig-iron, or sausages.

Yet, do not suppose that the seedsman is a natural enemy of small gardeners. Far from it. Some of the things I have bought from him were better than he advertised, especially as they acquainted me with the pleasures of hope. For, after all, it is not the product in which we 


\section{FLOWERS IN SEASON}

take the greatest joy: it is in the producing. We owe daily thanks to Adam for our garden practise and our habit of work. A man who has made things grow has been pleasantly and healthfully occupied, his imagination has been enlarged, but he does not believe in print to the same extent as before he began to read floral catalogues. Still, there is no doubt that the people who write catalogues, and more particularly, illustrate them, wish that flowers did grow just as they do on their pages. Why shouldn't they wish it? As compared with usual blossoms of the same names, theirs are as watermelons to mangel-wurzels.

In choosing flowers for the little garden you will pick out enough at the beginning to fill something less than three acres. The array you contemplate is as magnificent as any in the demesnes of royalty. But looking out upon the space at your disposal, and the figures that represent your bank-account, you sigh regretfully, run the blue pencil through your order and begin the practise of self-abnegation, which is alleged by those addicted to it to be good for one's morals.

$\mathrm{Up}$ here in the temperate zone we can not 


\section{I T T LE GARDENS}

have the flowers, even in our greenhouses, that make the tropics gaudy. We have vegetal beauty and abundance of it; but there is no such wonder of grace, such passion of color, such extravagance of perfume as we find, say, in the West Indies, where the tree jasmin loads the air with fragrance, and the flamboyant (poinciana regia) burns like the flaming bush and carpets the roads with red after a wind-a red more gorgeous than that of our October woods. When we do fetch an exotic into our yards, it may survive, but it will never be the same as in its native soil. So let us content ourselves with what shall grow with ease and certainty. If we can not have the jasmin we can cultivate the tuberose, which is as sweet; if not the flamboyant, we can have the croton, galax and poinsettia in our borders, and the sunflower, dahlia and chrysanthemum in our beds. And in buying plants you have before you two methods and a compromise. The first method is to fill your garden with hardy plants that come up year after year with little or no urging or attention. The second is to have a change of contents every year by setting out potted plants-annuals-that you 


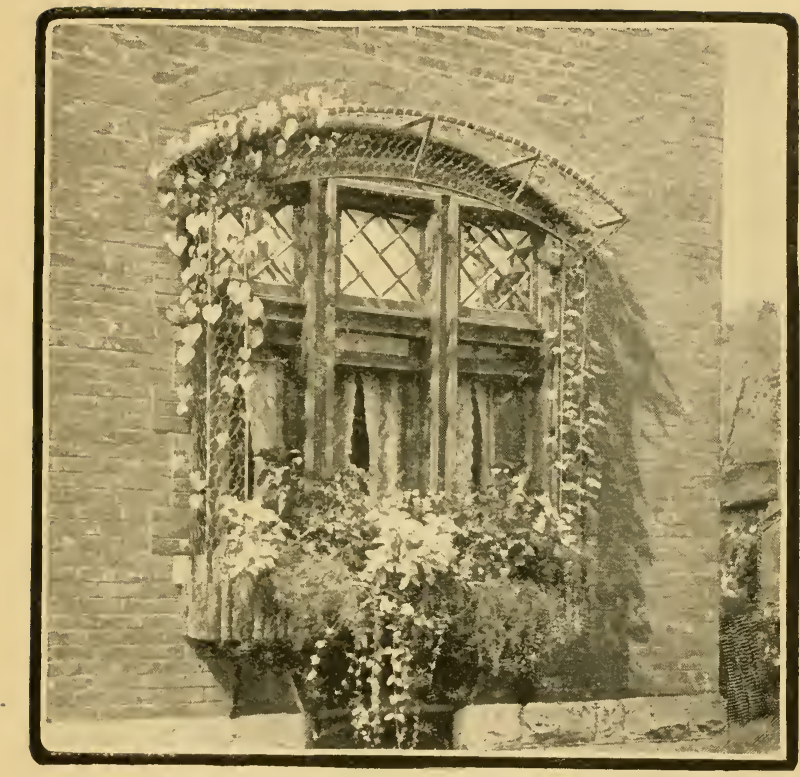

A WINDOW IN OHIO 



\section{FLOWERS IN SEASON}

buy from florists in the spring, or that you may raise from cuttings, seed and roots, if you have a greenhouse or a cold frame, and such plants will bloom once and be seen no more. The compromise is to give a part of your garden to the sure and sturdy things, and reserve places for annuals and opportunities and experiments. My own election would be for perennials, if I were bound to a choice, but one enlarges his knowledge and deepens his interest if he tries the effect of new soils and new conditions on plants with which he is unfamiliar. The common wild flowers are always inviting for this purpose, and are never more delightful than when we find them in the strange and seemingly uncongenial surrounding of a city yard.

If you resolve on the hardy garden, choose those plants that really are hardy and will not die in a sharp winter. A backing of bushes near the fence is desirable, any way, if you have room for them. If you have annuals, assign them to a separate space, where the spading and planting will not imperil the roots of the perennials already in the ground. Study the cultural directions given on the seed-packets, but remember 


\section{I T T LE GAR D E N S}

that some annuals, like the poppy, hollyhock and portulaca, seed themselves so abundantly that you have no need to plant them after the first year. Arrange the garden so that the smallest of its contents shall be nearest. For the back row plant vines and flowering bushes-lilac, rose, rudbeckia, syringa, rose of Sharon, rhododendron, snowberry, snowball, smoke-tree, weigelia, oleander (to be taken indoors in cool weather), even a small magnolia; or, tall annuals like hollyhock, sunflower, artichoke or elecampane. These will stand at a height of from five to eight feet and will cover your fence from view. Then, before them can be set things like the tall varieties of phlox, dahlia, golden-rod, Joe Pye-weed, marshmallow, yucca filamentosa and mullein. Why, but these last are weeds! As you please. A weed by the name of a garden flower is quite as handsome as many garden flowers that are weeds in their own countries. Our mullein, for instance, is really a distinguished vegetable, and if it were less common we should raise it in our conservatories alongside of our orchids and gloxinias. In Holland it is cultivated, and is spoken of respectfully as the 


\section{FLOWERS IN SEASON}

American velvet plant. Then, a step lower than these we can have the peony, Dutchman's breeches, bleeding-hearts, larkspur, cardinal flower, lily, iris, the common daisy, canna, salvia, gladiolus, tuberose, Canterbury bells and others of a like stature. Still advancing toward the path, for you will not hide the small plants by putting the big ones in front, are poppies, columbines, gas-plants, funkia, candytuft, pinks, the low-growing phlox, balsams, zinnia, mignonette, heliotrope, indeed, a majority of the garden favorites. Of course, if these plants-or any other - are used, their color relations must be considered, not less than their height, and in planting we must also regard their habit of growth: not merely whether they grow lengthwise, but whether or not they spread out sidewise. If this matter is neglected we may plant a gaillardia or amaryllis, and have to look for it later under the spread of a stramonium, or find it strangled in the clasp of a clematis or woodbine.

It was Lord Bacon's idea that a garden should always be in bloom. So it should, and so it will not be. Bacon's quaint essay on the subject supposes an immense tract laid out with ave- 


\section{I T T LE GAR DEN S}

nues, arbors, fountains, lawns, and an edge of wilderness. In a space like that it would not be difficult to have a succession of blooms so long as the weather permitted any. It is worth while to quote from this discourse, if only to observe how little or how much of the English language has become incomprehensible in the last three centuries :

"God Almightie first Planted a Garden. And indeed, it is the Purest of Humane pleasures. It is the Greatest Refreshment to the Spirits of Man; Without which, Buildings and Pallaces are but Grosse Handy-works: And a Man shall ever see, that when Ages grow to Civility and Elegancie, Men come to Build Stately, sooner then to Garden Finely: As if Gardening were the Greater Perfection. I doe hold it, in the Royall Ordering of Gardens, there ought to be Gardens for all the Moneths in the Yeare: In which, severally, Things of Beautie, may be then in Season. For December, and January, and the Latter Part of November, you must take such Things, as are Greene all Winter; Holly; Ivy; Bayes; Juniper; Cipresse Trees; Eugh; PineApple-Trees; Firre-Trees; Rose-Mary; Lavan- 


\section{FLOWERS IN SEASON}

der; Periwinckle, the White, the Purple, and the Blewe; Germander; Flagges; Orenge-Trees; Limon-Trees; And Mirtles, if they be stooved; \& Sweet Marjoram warme set. There followeth for the latter part of January, and February, the Mezerion Tree, which then blossomes; Crocus Vernus, both the Yellow, and the Gray; PrimeRoses; Anemones: The Early Tulippa; Hiacynthus Orientalis; Chamairis; Fretellaria. For March, There come Violets, especially the Single Blew, which are the Earliest; The Yellow Daffodil; The Dazie: The Almond-Tree in Blossome; The Peach-Tree in Blossome; The Cornelian-Tree in Blossome; Sweet-Briar. In Aprill follow, The Double white Violet; The IVallflower; The Stock Gilly-Flower; The Couslip; Flower-Delices, \& Lillies of all Natures; Rosemary Flowers; The Tulippa; The Double Diony; The Pale Daffadill; The French HonnySuckle; The Cherry-Tree in Blossome; The Dammasin, and Plum-Trees in Blossome; The White-Thorne in Leafe; The Lelacke Tree. In May, and June, come Pincks off all sorts, Specially the Blush Pincke; Roses of all kinds, except the Muske, which comes later; Hony-Suckles; 


\section{I T T L E GAR DENS}

Strawberries; Buglosse; Columbine; The French Mary-gold; Flos Africanus; Cherry-Tree in Fruit; Figges in Fruit; Raspes; Vine Flowers; Lavender in Flowers; The Sweet Satyrian, with the White Flower; Herba Muscaria; Lilium Convallium; the Apple-Tree in Blossome. In July come Gilly-Flowers of all Varieties; Muske Roses; The Lime-Tree in blossome; Early Peares, and Plummes in Fruit; Ginnitings; Quadlins. In August, come Plummes of all sorts in Fruit; Peares; Apricockes; Berberies; Filberds; MuskeMelons; Monks Hoods, of all colours; Peaches, Melo-Cotones; Nectarines; Cornelians; Wardens, Quinces. In October, and the beginning of November, come Services; Medlars; Bullises; Roses Cut or Removed to come late; Hollyhokes; and such like. These Particulars are for the Climate of London; But my meaning is Perceived, that you may have Ver Perpetuum, as the Place affords."

Your yard shall be the clock of the seasons if you plant with reference to the flowering time. Thus, we put bulbs into the earth in fall, for their appearance so soon as the snow is gone. The first warm days bring points of green to the sur- 


\section{FLOWERS IN SEASON}

face, and before the trees have shot out a leaf we have the crocus, white, blue and yellow, clinging to the ground as if to retire if it had miscalculated its chances for prosperity. In their hardihood some of the spring flowers are deceived, and are cut down in a night by sudden and cruel freezes. We prize these drops and flashes of color at more than their intrinsic worth, no doubt, because they are the first. We should not care a great deal for the anemone, the bloodroot and the liverwort if we were to find them in the summer. The opulence of loveliness that surrounds us then would blind us to the modest and brave little creatures that are its heralds. Still, not all the spring flowers are small. There are hyacinths, most prized of the bulbs, with spikes of white, pink and pale-blue flowers, thick-set, often double, deliciously fragrant, and fairly lasting; for, so early in the year few insects have arrived, and it is the effort of flowers to last until the insects, seeking nectar, fertilize them and "set" the seed. Then we have the freesia, fine, delicate, well-nigh as fragrant as the hyacinth. Other first appearances that inaugurate the eight months of bloom are those of the grape hya- 


\section{I T T L E G A R D E N S}

cinth, crown imperial, snowdrop, bluebell, the bellis or English daisy-the "wee, crimson-tippit flower " of Burns's apostrophe, which I have found, self sown, as an escape from American gardens; and in your wild corner, if you have one, the tawny lily that we call dog-tooth violet, because it is not a violet and does not represent a dog's tooth, and is as unwisely called adder'stongue; the fragile spring-beauty, squirrel-corn, the anemone; then, among the woods we come upon the Dutchman's-breeches (if this name offends you, call them white hearts) and trailing arbutus, that peddlers tear up from the New England and Long Island woods to hawk about our streets. Before April is over we have in our gardens the candytuft, clarkia, gilia, California poppy, Drummond's phlox, daphne mazereum, goldenbell, June-berry, shadbush, spicebush, Judas-tree, Japanese quince, and such boughten things as you may have had from the florist and put into your flower-beds, pots and all, against the sharpness of spring winds.

There is little danger from frost in the latitude of New York after the beginning of May, although the month may be raw and the output 


\section{FLOWERS IN SEASON}

of flowers but slight. In that season the columbine, everlasting, jack-in-the-pulpit and wakerobin are springing in the glens, and in your yard, if you have planted them, you may watch for the moss-pink, daffodil, jonquil, tulip, summer snowflake, dogwood, tulip-tree, magnolia, barberry, kerria, lily-of-the-valley, silverbell, forget-me-not, lamp-plant, rock-cress, tree-peony, sweet alyssum, godetia, marigold, ten weeks' stock and baby's-breath.

In June the garden will be in full flower; the sweet peas will enrich the air, the morning-glories will open their eyes to the sun before you open your own, the roses will unfold their damask to the butterfly, the lilies will arise to teach their seldom-heeded lesson of humility and worth, the nasturtium will reflect the warmth as well as the light of summer, and while the fields and brook sides are ablaze with dandelion and buttercup, you, in your pleached garden may rejoice in the peony, iris, wistaria, pelargonium, cineraria, marigold, amaryllis, and, in the wild garden, the harebell, Solomon's-seal, shooting-star, bunchberry and columbine.

Color flows in high tide across the earth in 


\section{I T T L E GAR D E N S}

July. All the tender things we house during the cold season are in bearing out of doors. The locust and catalpa have dropped their blossoms, the rhododendrons are passing, but the syringa exhales its luscious odor, if it is one of those years when it deigns to do so, the chestnut is putting out its belated, rusty looking clusters; in the fields are seen the golden stars of the St. Johnswort, the button-bush, pepper-bush, and in wild ground in the South the yucca has thrown up its candelabrum of wax-white blossoms; while the beds are aflame with zinnia, crinum, spirea, pansy, pink, bachelor's-button, salpiglossis, the red and yellow lilies, coreopsis, calceolaria, geranium, painted daisy, balsam, cockscomb, lovelies-bleeding, four-o'clock, gaillardia, phlox, nicotiana, portulaca, (this seeds itself, and will grow next year,) alyssum, fuchsia, scabiosa, white and pink yarrow, sweet-william, and on our arbors, the cobœa, honeysuckle, moonflower, passion-flower and Dutchman's-pipe are spangled with bloom.

The fierce heat and sultriness of August are tempered by a continuance of most of these blossoms, and the showering of the garden with a 


\section{FLOWERS IN SEASON}

hose, on a still, warm evening, is a more composing occupation than struggling with a crowd at the beach or listening to rag-time music on a roof. The vines now blooming include not only those just named, but the wild bean, the nightshade, the balloon, the trumpet-creeper, the virgin's-bower, the Japanese hop, the perennial pea; the hydrangea has put out its bunches of dull pink and greenish-white flowers, long lasting; the blue spirea, the sweet alder, balm, lychnis and maurandia are at their showiest; and the giants, the sunflower and hollyhock, lend of their pomp.

September continues the pageant with canna, gladiolus, ageratum, candytuft, musk-plant, cosmos, heliotrope, verbena, zinnia, funkia, giant daisy, rudbeckia, dahlia, mignonette; the cardinal-flower blazes on the edge of the damp wood; the witch-hazel puts out its uncanny little sprays; in the hills the sweet peas are at their best; there are the late roses, too, and the dahlia, poppy and nasturtium are gay in the country gardens. In the bulb corner the tiger-flower and blazing-star have emerged, the Japanese anemone and showy sedum are up in the rockery, the boneset is feath- 


\section{I T T L E G A R D E N S}

ering in the pastures, the pondweed and waterlily add color and fragrance to the pools.

In October the flowers are in rivalry with the trees, for the mountain sides are gardens, and the maple, beech, birch, oak, sumac, brambles and a thousand lowly things paint the scene with splendor. Now the asters, wild and tame, constellate the gardens and the roadsides, and late goldenrods add touches of warmth to the chilling fields and to the hollows among the dunes. If the frosts have held off, the stout old favorites of the garden are still putting forth and the bees are humming over them. We find the petunia, gaillardia, alyssum, candytuft, clarkia, godetia, marigold, stock, goldentuft, poppy, blue spirea, sedum, starwort, sunflower, hydrangea, daisy fleabane, which-hazel and swamp-flower. We are also likely to find freaks-plants that have decided to bloom a second time or put out a second crop of fruit. I have seen a horse-chestnut, stripped of one clothing of leaves by caterpillars in a birdless town, put forth a new crop of leaves and a multitude of blossoms in the fall. The last rose of summer may be found blooming in October. I have never been in the country in 


\section{FLOWERS IN SEASON}

that month when I have failed to find raspberries in bearing, and in the White Mountains, after several nights of frost, I have battened on blackberries, and have noted how active the foxes had been in gathering the fruit before me. We are liable to have a fresh output of honeysuckle, and the dahlias are lingering. Dandelions I have found in bloom on Long Island in every one of the twelve months, though not of the same year. But October is the month of the chrysanthemum, and unless the weather becomes intolerably cold it lasts into November. It seems as if nature made a final effort to hold the admiration of her children; hence she beams up from the fading earth with a smile, fitful and pathetic, yet as bright as summer.

In November we find lingering a geranium, possibly, or a petunia, or some of the coarser wayside growths, but the beauty of the garden has passed, unless it is a Southern garden, or a garden in California, for there it is always spring in the air and summer on the earth. It is the certainty of winter, however, that makes us, who have it, prize the fleeting beauty of the garden all the more, though we may envy the people of warm 


\section{I T T LE G A R D E S}

places in that the flowers they grow are so large, so gorgeous and so late. Not that this invariably applies, for some plants prefer the cold, and I have never seen finer sedums than are grown in the public gardens of Halifax, nor does the camomile put out bigger blossoms than on the rocky shores of New Brunswick.

Maybe you would prefer to plant for color, rather than for season, for in that you have the joy of all seasons. When I am rich and have ten acres I shall have color beds in my garden, so that I may enjoy a blaze of yellow now, a rousing, martial red at another time, and bring down the sky upon my kingdom, or simulate the snows in fragrant white. I will have spaces for daffodils, yellow iris, cowslip, yellow lilies, chrysanthemums, goldenrod, cloth-of-gold and Persian roses, calceolaria, coreopsis, coneflower, columbine, cinquefoil, canna, helipterum, marigold, nasturtium, escholzia, zinnia, gaillardia, goldentuft, St. Johnswort, black-eyed Susans, barberry, honeysuckle, currant goldenbell, kerria Japonica, dahlia, yellow water-lily, buttercup, elecampane, and the big, honest sunflower-we raised one last summer that was eighteen inches across the 


\section{FLOWERS IN SEASON}

disk-while in the borders will appear the yellow shades of alternanthera, coleus, pyrethrum, iresine and cockscomb.

Then, either at another season or in another place, shall be a bravery of red roses, blooming in beds edged with the red and variegated alternanthera, iresine and acalypha; here, too, shall be the geranium, the cardinal-flower, poppy, rhododendron, azalea, chrysanthemum, aster, lotus, salvia, Chinese primrose, red lilies, begonias, morning-glories, currant-a reckless mixture of species and seasons, thisdiervilla, spirea, Japanese quince, burning-bush, balm, stock, peony, coral bells, phlox, Japanese anemone, carnation, amaryllis, gaillardia, helichrysum, portulaca, verbena, zinnia, love-liesbleeding, and, most gorgeous of all, the cockscomb. This is not a true flower, but nothing in the world has finer color. It is the deepest, richest red conceivable; the most intense ruby and garnet; the most vivid stripe in the rainbow. No rose blows more glorious red, and rarely do we see the like at sunset. The orange cockscomb is no less wonderful, and as a decoration we need both. 


\section{I T T L E G A R D E N S}

Then, in the cooler beds of pink there should be hyacinth, bouncing Bet-don't misprize this fragrant and pretty blossom because it grows wild-amaranth, balsam pink, clarkia, cosmos, sweet pea, gillia, bleeding-heart, lychnis, hollyhock, peony, dianthus, and in the pond the tinted water-lily and that splendid borrowing from the East, the lotos, though this likewise occurs in white and pale blue, as to its flowers.

In the blue and purple beds should appear the hyacinth, grape hyacinth, fleur-de-lis, violet, columbine, cineraria, heliotrope, hyacinth bean, mourning-bride, ageratum, bachelor's-button, lobelia, nemophila, blazing-star, shooting-star, aster and larkspur.

As for white, there is no end to it. One can help himself to syringa, weigelia, rhododendron, azalea, moonflower, crocus, hyacinth, tulip, iris, daisy, rose, lily, water-lily, lily-of-the-valley, achillea, yucca, nicotiana, phlox, sweet pea, sweet alyssum, columbine, tuberose, stock, rock-cress, candytuft, geranium, baby's-breath, pansy, aster, chrysanthemum, petunia, dahlia, peony, bean, honeysuckle, snowball, snow drop, hydrangea, and so on, from wistaria down to portulaca. 


\section{F L OWERS IN SEASON}

All this time I am not forgetting that there are to be lawns to frame and offset these splendors. Never forget that grass is to be your richest crop. You will rest in its color, it will be carpet to your feet, and after the mowing it will reward you with fragrance, at least, if you have mixed clover with it. Our soft-breasted earth yields treasure to her children for the asking, yet never in such free wise as at haying time. And by keeping to beds of a single color, as you agree to leave your lawns to the single color, green, you gain a simplicity which the eye best comprehends. You need not sacrifice variety to obtain it, but merely allow flowers of a petal to group together. They are happier in one another's company than in that of strangers. 


\section{VI}

THE CHOICE OF FLOWERS

IN making a choice of flowers for the home garden do not buy exotics and tender things. They will not grow, at least, without housing in the winter; and if you own the usual little house and little patch of ground around or back of it, you can hardly add a conservatory to your establishment. Plant the hardy things. And first of them is the rose. This flower, in its various phases modest, flaunting; demure, sumptuous; timid, aggressive; solitary, social, is probably the oldest of all the treasures of the garden. It is the flower of Venus and of Mary; it has wreathed the brows of emperors and martyrs, of poets and revelers; it has figured, not merely in sentimental and religious traditions, like those of St. Rose and St. Elizabeth, but in history, for had we not a war of the roses? Of our garden it is queen; or shall we give that rank to the lily, and greet the rose as king? There is a mascu- 


\section{CHOICE OF FLOWERS}

line, rather than a feminine splendor in the American beauty - a French variety, by the way, that thrives best in our soil-and the habit of the bush, in taking what it wants, and in clinging to its vantage in the soil, is virile. The old-fashioned, sturdy kinds are best: those that defy the seasons and outlive neglect and wreck. Last fall while scrambling through a lonely region in the Green Mountains, I came upon a cellar on a deserted farm. The building which once stood above it had entirely rotted down, a jungle of vegetation covered its dooryard, but tall and strong above a thicket of raspberries stood a bush of damask roses, flaunting year after year, untended and unseen. Of all that the farmer had planted, this and a few gnarly apple-trees survived. The homeliness of farm life had vanished, and a faint echo of its beauty came out of the past. Three or four miles away I culled a bouquet from a self-extended thicket of crimson roses before another deserted place. Now, plants that behave like that are good to know, and to grow up with. They are as reliable as grass. Their yearly appearance, their opulence of scent and color, endear them to us as home 


\section{I T T LE GAR DENS}

is endeared; for they become, literally, a part of it. I hope to see, one day, such rose farms as they have in France and Persia; acres, yes, miles of red and white, grown for the attar and other extracts, but though we have none of them we can still make our gardens beautiful. For some nurserymen are devoting themselves entirely to roses, thereby seeming to betoken the unfailing popularity of the flower, and their list of varieties is surprising, not to say, confusing. After trying sundry of the new strains I go back to the standards with increasing satisfaction. The new varieties, especially those of dwarf habit, delicate color and tea fragrance, are floral toys, made only for the greenhouse, or for balmy lands where the natives never feel the invigorating frosts of the North. At least, my experience is that such roses peak and pine out of doors, even in genial weather, they are subject to insect pests and diseases that less affect the larger bushes, and they are uncertain in their blooming. Of a number that I set out in a sheltered yard one summer, all died but two or three, and they exhausted themselves in putting forth their buds. Last summer a dwarf plant gave birth to a huge 


\section{CHOICE OF FLOWERS}

pink rose, as large as a La France and of fine fragrance, but it killed itself a-doing it, for so soon as the petals fell the bush shriveled into the ground and was seen no more. Wherefore, I say, place your reliance on the tried and true, unless you have a greenhouse, or desire to experiment. The best of roses will not grow for us in the East as their humbler sisters will flourish for the Californians, but the effort to bring them to a sturdy maturity is self-rewarding. Of the better known of the tea-roses, mention is due to the Maréchal Niel, La France, Mermet, Bon Silène, Bride, Meteor and Mme. de Watteville. These do well in the South, but do not look to see them survive a New England winter out of doors. Of the reliable kinds there are, among the reds, the Jacqueminot, often called Jacks by florists, Rosière, De Rohan, Wilder, Verdier, Carrière, Rothschild, D'Aumale, Libaud, Bernardin, Neyron and Bruner; among the pinks, Magna Charta, Favorite, Christy, Prince of Wales, Prevost, Lyonnaise, Rothschild and Verdier; of the white and blush roses, Mrs. Paul, Élise Boelle, Mabel Morrison, Margaret Dickson, Altaica, Perle des Blanches, Hybrid China; 


\section{I T T L E G A R D E N S}

of the moss-roses, Hermosa and Clothilde Soupert; and there are the climbers, Dawson, Carmine, Pillar, Wichuriana, Seven Sisters, Thalia, Prairie Queen-sturdiest of them-and Mary Washington.

It may be that some of the old strains do not bear as they did; that they have been urged to exhaustion, like the potato, for the scientists tell us how in propagating this tuber from eyes, instead of seed, we have violated the method of nature, and as a consequence, the potato will disappear, along with the buffalo, the dodo and the Indian. You have noticed, of course, that potato plants seldom bear their balls or seed pods now, although they did thirty years ago. It is against the popularity of the rose that, on some bushes, the flowers do not remain so long as could be wished, yet there are other varieties which are quite as enduring as any other plant that we grow, unless we may except the geranium. I have had a hybrid blooming in my yard for a month together, and it often happens that a second crop of flowers appears in the fall. This is a bushy rose, six feet high, bearing flowers of mingled pink and white. We are told that once, 


\section{CHOICE OF FLOWERS}

when St. Francis of Assisi was tempted by thoughts of comfort and sufficiency, he rushed from his cell, stripped off his robe, and rolled in the snow. There were briers in the drifts, and wherever they brought blood the snow disappeared and the crimsoned stalks burst into bloom; but, lo! only half the petals were red: the others were as white as the snow and stainless as the spirit of the saint. My rose, I think, came from Assisi.

I require that a rose have fragrance, whether it has endurance or not. Hence, I have small enthusiasm for the ramblers, crimson, yellow and white, that have attained a sudden vogue with us, and that produce bunches of small, papery, scentless flowers. For me they produced nothing, for they died promptly and made way for something stouter. Yet they are pleasant to look at: these wiry little climbers. They are decorative; they bear hundreds of blooms, in clusters as large as a fist; and when they spring from a congenial soil they climb vigorously and their leaves are green and wholesome, therein contrasting with the foliage of some relatives, which turns rusty, at least, in town, and is much 


\section{I T T LE GARDENS}

beset by worms, beetles and thrip. The two former you often dislodge when you shower the plant with a hose, and you may throw some of them to the ground by shaking the bush, in which case you will shake off more petals than insects; but the thrip, which in its nymphal form is a whitish fly, hardly an eighth of an inch long, with a baffling, parabolic manner of flight, clings to the under side of the leaves and escapes wetting and observation. Soot has been used to destroy these vermin, but a bush covered with soot is even more unsightly than a bush covered with parasites, because you can see the soot. And again, there is not much soot in town; at least, there should not be, for it gathers thickest where we permit the burning of soft coal and the making of impure gas-enemies of gardens, by the bye. Powdered white hellebore, in solution, syringed over the bushes, is said to be harmful to thrip. If the new ramblers are unsavory to these little feeders, that, to be sure, is a reason for cultivating them; yet I think there is no plant that is not a joy to some manner of creature that we believe ought not to be there.

Why is it that we see so few of the yellow 


\section{CHOICE OF FLOWERS}

roses any more? Has our use of the term yellow, as an adjective of contempt, and applied to vulgar and vicious things, made us afraid of using this joyous color? True, you see magnificent cloth-of-gold roses on the Pacific slope, great vines and bushes of them that bury a cottage out of sight, and Yankeedom clings to its old Persians, but the yellow rose has elsewhere fallen into a neglect that is wholly undeserved. Let us not revolt at a mere name. We are assured, on high authority, that a rose by any other name will smell as sweet. Where the yellow roses bloom, one spot of earth is gay with sunshine. The sun may shine in our north, too; at least, the growers vouch for the hardiness of the standards and especially commend the Belle Lyonnaise, Harrison's Yellow and the Persian. If you buy them, get such as are "on their own roots"that is, not grafted-for they are strongest, and flower most plentifully.

Of late some use has been made of the rosa rugosa, a wild variety from Asia, in parks, hotel lawns and other places where strong vegetation and solid masses of green are needed. A bush of it is not a bad centerpiece for the little gar- 


\section{I T T LE GARDENS}

den, for it bears abundance of pink and white flowers, bright and cheerful in color quality, and single or double, as may chance; while its big red haws are almost as decorative as flowers.

Our common wild rose or sweet-brier is one of the pleasantest of familiars, and one of the most fragrant; but it is not lasting, and it can not be cut for bouquets, which facts, no doubt, have prevented it from gaining a hold in our gardens it might otherwise deserve. Whatever roses we employ, it is best to group them into beds or clusters, or keep them near the fence, if the ground is small. In November they will endure the cutting out of weak growths, and in the spring, of sprawly new ones. Some gardeners cut down all roses to within a few inches of the ground, at the coming on of winter. Though my own roses have defied cold weather, it is safest to wrap the stems in sacks when snow is due, to heap earth above the roots, and strew old manure and straw over the beds. A spring manuring does more good than fertilizing in the fall, but the snow covers from sight what is never pleasant, while in the spring the plant food asserts itself to at least two senses. 


\section{CHOICE OF FLOWERS}

Next in importance to our roses-to many the most important of all the garden contents, since they are the largest objects, and have the use not alone of beauty but of hiding the unbeautiful-are vines. And by all means cultivate a honeysuckle. Train it over a trellis at your back door, or over a part of your fence. If you have any sheds or unsightly buildings on your premises, cover them with it. Its flowers are not much to look at, but the deep, strong green of its leaves stays through the winter, at least where it mats together, and there is nothing more delicious than the odor breathed through its tiny trumpets in call to the bee. If I could have but ten flowers they should be the rose, lily, lily-of-the-valley, lilac, nasturtium, petunia, pansy, sweet pea, aster and honeysuckle. This vine can safely be left to itself, once it has been started, and it needs no more than occasional thinning out, for it has a tendency, on arbors and summer-houses, to put out such masses of leaves, and to so knot and twine itself together that it forms a screen against the air and light. It can be employed to cover walls of brick or stone, and there is an estate in Tarrytown, N. Y., 


\section{I T T LE GARDENS}

which for a mile is hedged with honeysuckle. A walk past the grounds on a quiet evening, with delicate incense pouring from a million censers, is a memorable experience. It can also be grown near the sea, and visitors to Brighton Beach will recall the veranda of the immense hotel, partly overgrown with honeysuckle, its exquisite fragrance mingling with the saline pungency of the ocean that roars and pounds but a stone's toss distant.

A useful and handsome vine of larger expansion and more rapid growth is variously known as Boston ivy, Japanese ivy, and ampelopsis. It has a leaf resembling that of the maple, only more compact and shiny, and in October it vies with that tree in the beauty of its color. It is almost the only plant that shows autumnal tints in town, for there is that in the air of a city which causes vegetation to rust and wither when it has ripened, instead of taking on the sunset glories of the woods. This ivy is a tremendous grower. It will blanket a three-story front in a couple of years, and sprawl over two or three buildings on either side. It throws out hundreds of branchlets that dangle from the stronger stems 


\section{CHOICE OF FLOWERS}

and are covered with tiny resinous drops. These are to be persistently snipped away, for they will creep in at window-casings, between sashes, through area gates, under doors and over chimneys; they will fasten their little suckers against stone, brick or wood; and pretty instances of this covering occur in the permanent awnings of wire, which are supports for the ivy and make a frame of green for the view, as seen from within.

Another quick-growing, wide-spreading vine, of use in covering displeasing buildings and barring dull views or transforming tall fences, is the cobaa scandens. Its large leaves are of especial service in concealments, although it has not the charm of fragrance and its flowers are less beautiful than those of some other creepers and clingers. It may cause trouble from the reckless way in which it extends itself, for it will lay hold upon anything, whether clothes-lines or flower-stems, and seem to mock the efforts made to curb its pranks.

In the country, too, they are beginning to see that the common gourd, cucumber, squash and pumpkin vines are of value as curtains and decorations. The pumpkin, especially, with its big 


\section{I T T L E G A R D E N S}

leaves, can be taught to clamber over sheds, rickety walls and fences, stone-heaps, ash-heaps and other disagreeable happenings, while it makes a superb setting for a back door. Take one pumpkin out of the corn-field, and let it have the run of the back porch.

The wistaria, beloved in the East, but in none too common use in our country, is a pleasant vine and an early bloomer, putting out compound leaves that are light and graceful, and fine clusters of white or pale-purple flowers that look almost like bunches of ripening grapes, at a little distance. These pendant masses of color are particularly charming, and are unlike the bloom of any other cultivated vine. The Japanese make an effective use of the wistaria as an enhancement to the grace of arches and bridges, the screening of rockwork, and in covering the trellises of tea-gardens. Vines in full flower suggest jets of water leaping from a fountain's lip, or the shower of colored lights from a rocket. The wistaria is of slow growth, and in our climate requires years to establish itself; still, once with you, it means to stay. Its stem grows thick and tough, it strengthens itself by gnarling its 


\section{CHOICE OF FLOWERS}

various branches together, and it grasps a tree with a veritable strangle hold. One in a yard in New York has put out a mass of wood nearly equal to the tree that supports it - an aged tulip, I think-and were the tree to fall, the immense trunk of the wistaria might continue to hold the mass of the vine somewhat above the earth.

There is nothing like morning-glory for covering fences and sheds. Once admit this vine and it will befriend you forever. If it remained where you put it you could make no objection, but it will by no means do that. Its flowers of white, pink, purple, delicate mauve and blue would justify it for your use, even if its clean and thrifty foliage did not. It is a swift grower, a copious bloomer, a useful and pretty plant, that deserves not to be discouraged. In Dayton, O., where so much has been done to make mechanic labor content with its lot-so much in the way of prizes, free libraries, reading-rooms, recreationrooms, cost-price restaurants, baths, rest-rooms, gardens, medical service, sanitation, music, lectures, picnics, schools; and after all, this did not prevent a long and bitter strike-a successful effort has been made to reform the appearance 


\section{I T T L E G A R D E N S}

of a rowdy district through the use of flowers, lawns, vines, window-boxes and greenery. The effect has been reformatory, not merely on the appearance of the quarter, but on the character of its dwellers, for it has become one of the quietest and most agreeable sections of the city. Until the renters were stimulated by offers of money for the best kept yards, the houses near the factories had a forlorn environment. They were surrounded by trampled grass, weeds, rickety constructions and refuse. Now, a view over the fences behind a house row will disclose abundance of flowers, and the morning-glory is especially in evidence as a covering for the fences. It fairly loads those partitions with bloom and leafage, and we have a park or garden where all was squalor. The morning-glories are actually rampant, and they pile upon the fence like green breakers, flashing with multi-colored bubbles in the early sun.

When the architecture is worth while we do not want to conceal it; and in almost any event we do not wish to cover it with vines so thickly that the purpose or form of the construction becomes a matter for surmise. If Boston ivy, for 


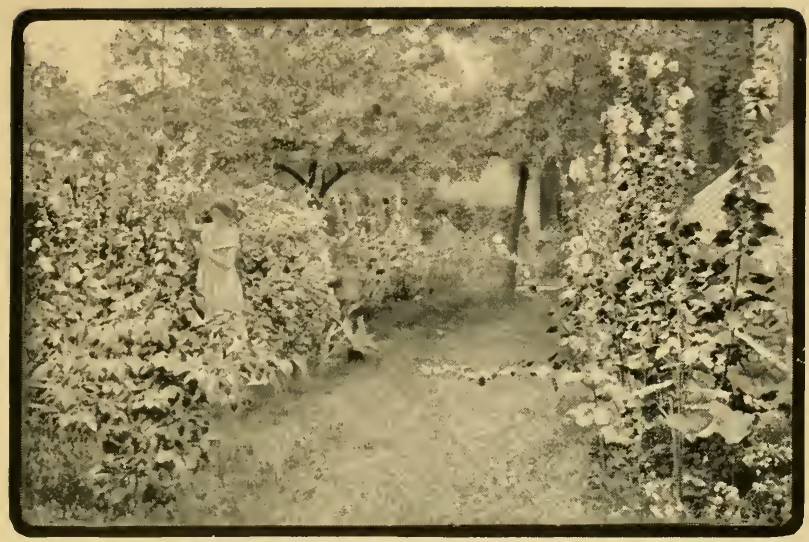

SHADE AND BLOOM IN PROFUSION.

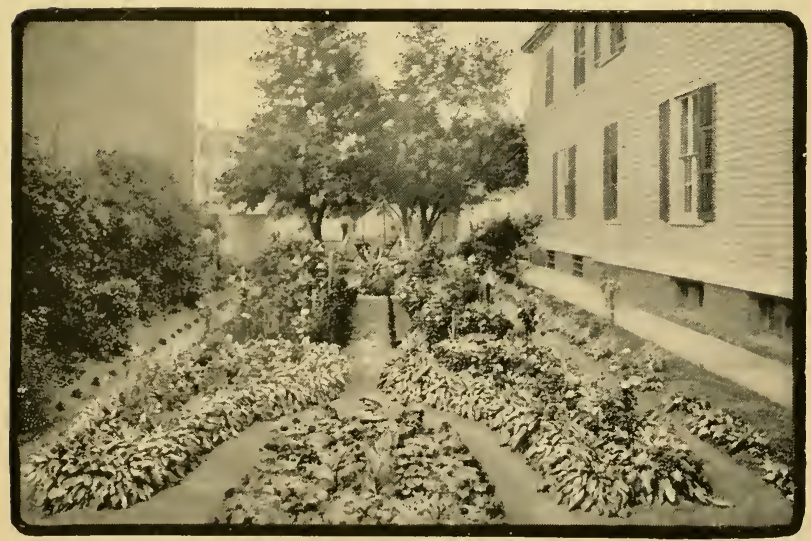

BEDS OF LETTUCE. 



\section{CHOICE OF FLOWERS}

example, were in the habit of throwing long twists of branches or bunches of flowers into the air, at right angles to its upright growth, we should not be sure of the form of the house on which it grew; but as it is, we lose nothing of the shape, because it fits itself so snugly to the bricks. Vines that pour over the premises, throwing a deep shade, especially through the windows and into the living-rooms, are to be avoided; and so are those, for house-front use, that wilt and turn yellow or rot with dampness or frost. ' Our morning-glory is not for attachment to houses, unless it is ruthlessly displaced when it has ceased to be green and to bear flowers.

Experienced physicians can practise medicine with ten drugs, and gardeners can produce all the effects they wish with half the variety of plants that the amateur considers needful. So, with wistaria, ivy, ampelopsis, honeysuckle and morning-glory, one hardly requires to extend his knowledge of vines; yet if conditions of soil or climate exact it, he can add or substitute for these indispensables the prolific cobæa, the excellent aristolochia, the moonflower, the trumpet-vine, 


\section{I T T LE G A R D E N S}

the Madeira vine, the canary-bird vine, the cypress-vine, the scarlet runner, the perennial pea, the Japanese clematis, the matrimony-vine and the passion-vine with its broad and open blossom in which pious teachers of the faith discovered the sacred symbols: the crown of thorns in the corona, the stigmas representing the nails, and the anthers the wounds. Our native passionflower, by the bye, produces a berry which is eaten by some people. A deal of food goes to waste in this country from not knowing where to find or how to use it. We must also remember the hop, which can be trained over large spaces. These are all easy growers, generous in bloom. In remoter parts of the country grounds, where ledgy and unkempt areas invite them, we can employ the roadside growths. There is the bittersweet, for instance, a skilful climber, dappled with orange berries, in the season; there is clematis, or traveler's joy-though why it is more of a joy to the traveler than wild grapes and blackberries I never could tell-with its hoary tufts and its decorative leaves; there is our woodbine, whose leaves rival the flowers in their October coloring; and there is even poison-ivy, 


\section{CHOICE OF FLOWERS}

though it is best to show consideration for the public, and to check this, rather than extend it. It is not an ill-looking vegetable, and in the fall it often takes on ripe and delicate tones of pink and orange which make it ornamental, and the harm it does, to such as can be harmed, is commonly due to the fact that it is so little recognized. It is sometimes mistaken for woodbine, albeit the plants are quite unlile. If the leaves occur in fives you are to know that it is woodbine, and you may put a finger on each leaflet; but if they are in threes, it is poison-ivy, and you are to treat it with respect. I handle it without gloves and with impunity, as I fancy most people can do; yet I have known persons to break into unseemly eruptions merely because they had passed to leeward of a thicket of this plant. In Chickamauga, the site of the great camp during the Spanish War, this weed grew as plentifully as the black snakes, yet there were hardly more than two or three soldiers to a company who showed the illeffects of contact with it, though the tales they told of the power of " poison-ivory" were dismal enough, and their appearance, with swollen faces, patched with ointment, which gave to them a 


\section{I T T L E G A R D E N S}

peculiar ghastliness, roused unfeeling laughter from the immune.

There is one other vine, which we seldom cultivate as such, yet that is useful where it is not desired to carry vegetation to a greater height than five or six feet, and that is the nasturtium. This usually grows so thinly when it is carried upright that there is no danger of its throwing the shade that the larger and heavier climbers will cast. And of course, there are the sweet peas, but we are to regard them less as vines than as garden plants. Vines are rather more human than shrubs. They are selfish. They grasp for support, and do not care what it is they rise by, so long as they rise. We say that the plant does not think, and possibly it does not, but its career symbolizes all life, and nothing in the physiology of the walking races is more wonderful than its adjustment of pistil and stamens to propagation by means of the insect that feeds upon it. Yet I am by no means sure that the vine does not see and feel and think, and in the wilful and unaccountable conduct of morningglories and sweet peas in reaching across spaces for support-how otherwise do they know it is 


\section{CHOICE OF FLOWERS}

there?-we have matter for deeper study than other garden problems offer.

So surely as our garden has roses it should have lilies. With roses, lilies and vines it is a garden in sooth. These flowers are apart from most others in form and mode of growth, and they are of surpassing loveliness. In their exquisite purity, their white humility, their exceeding fragrance, which one breathes with a sort of rapture, they stir, not merely admiration but emotions akin to those we feel in contemplating the qualities of the lily in a member of the human family: emotions of affection, touched with reverence. These are flowers that saints have borne about the earth, and are thought to bloom in heaven. The old masters show the angels wreathed with lilies. And they consort charmingly with the rose; that is, their simplicity and silver whiteness make them a foil to the other flower, passionate, rich colored, and its slender leaves are a contrast to the luxuriant bush. When we have planted a rose, a substantial, freeblooming damask, or a hearty old cabbage-rose, at the back of a bed, it can have no better company than a lily. Remember: we can use white 


\section{I T T LE GARDENS}

with anything, except black, which fortunately does not occur in flowers, but only in the evening dress of men-and dreadful guys they look at night, as their great-grandchildren will tell them a hundred years from now. Though a trifle tall for a border, any or all of the lilies will make a good appearance against a green background, care being taken to avoid such other contrasts as cheapen the red and yellow of some varieties when placed near other flowers. The wood-lily and tiger-lily, for example, are of a tawny or foxy shade that suffers by contact with the crimson of a rose, the pink of a peony or even the scarlet of a geranium. They can better abide near zinnias, marigolds, nasturtiums and coreopsis. Of hardy varieties, like the candidum, auratum, speciosum, longiflorum, tenuifolium and funkia, all are safe to plant about the beginning of November, in partly shaded beds, at a depth of five or six inches, and during their first winter out of doors the bulbs should also be protected with a mat of leaves, or old manure. Other plants ask the same kindness, in their first winter, and it is as well to grant it to all of them, whether they ask it or not. The loss by frost 


\section{CHOICE OF FLOWERS}

will be less, and the bloom will be earlier and more abundant.

Bearing the name of lily, but of a different family from our queens, is the lily-of-the-valley, a pearl in the garden crown, a blossom with spring in its breath, a symbol of innocence and humility. The only fault I urge against this plant is that it does not bloom forever. That it is said to be a poison affects me not a whit, so long as it feeds my eye and nose. Leave a little space for it in the shade of the house, or of the wall, enrich it, and leave it to itself. Its hardiness commends it for the carpeting of odd spots that are shady and damp, though myrtle, moneywort and partridge-vine are better liked because they grow more thickly, and their green lasts longer.

So close akin to the lily in leaf, form, shape of flower and carriage of it that they are supposed by many to belong to the same family, are the zephyranthes, which put up a six-lobed bell of pink; the tigridia, topped with a fantastic, orchid-like blossom of a scarlet, at once soft and bright; the amaryllis, of a red usually more sullen, though rich and deep, and a habit more

$$
\text { I } 65
$$




\section{I T T LE GAR DENS}

assertive; and the crinium, even more proud and flaunting. But all these require coddling. They must be taken in during the winter, and rested; or they can be kept indoors as window-plants; and at best they are uncertain. An amaryllis that bloomed regularly and splendidly on a hill farm in Vermont, behaved sulkily when it was translated to New York, though it did give a good account of itself a year or two later. If one has no greenhouse, or cold frame, he may feel obliged to forego the cultivation of many flowers that tempt him in the seedsmen's catalogues; yet a dry, clean cellar, which is cool but never frosted, suffices for the keeping of bulbs, tubers, corms and roots that require removal from the soil for the winter. Such roots ought to be first dried, then placed in paper bags, plainly labeled in ink, and so stored on shelves or in boxes that the name shall be upmost, for otherwise moisture from the root may obliterate the writing, and I have found that one is able to forget various things between November and March-so many that, in the first season, at any rate, it is well to mark the place of each plant with a stake, (a clothespin will do,) after its 


\section{CHOICE OF FLOWERS}

stems have died down. Because of neglecting this I have played mischief with some of the hardy things in the soil; I have attempted, for instance, to set out heliotrope and mignonette in spots already occupied by tulips and chrysanthemums, with results disadvantageous to the latter. A faithful gardener will not only indicate his buried treasures by stakes or stones, but he will make a map of his territory and mark upon it the place and name of each of them.

For early bloom, among the hardy species, we rely on the crocus, hyacinth, grape hyacinth, narcissus, daffodil, snowdrop, snowflake, tulip, squill and trillium. These all arise from bulbs, which should be planted in three inches of light loam in the fall, but which are sometimes put into the earth on a mild day in January, when there is no frost in the bed, and when they are well mulched to prevent nipping by frosts that are sure to pinch our noses before spring fairly opens. The bulb plants, particularly the crocus, squill and tulip, are excellent for massing. The others are at their best when planted as borders.

None of these, save the tulip, which makes all too brief a show, gives to the garden the richness 


\section{I T T L E G A R D E N S}

that comes to it later in the season, when the dahlia blooms; but this is not a hardy plant. Its tubers are to be taken up and dried, after the top has withered, the new growths divided from the old, and all kept in the cellar till it is time for planting in early spring - a treatment that may be given to the canna and gladiolus, also. You could fill your yard with dahlias yet have hardly any two plants alike, for there are something like four hundred varieties, widely diverse in height, form and color. They range through a gamut of red and yellow, with strains and touches of intermediate orange, and they appear, likewise, in pearly white, which affects both of the basal tints, so that we have refined pink, ethereal yellow, and blossoms dappled and streaked in wilful fashion. The dahlia comes at a time when flowers are welcome, when chill weather is impending, and when most of the tender things have ended their year's delight. Its fresh, strong-looking foliage is no less charming, as the tree leaves begin to fall, than are its flowers. Its bloom varies considerably in size, from hard little nubbins, which seem to have tightened their petals to keep out the cold, to 


\section{CHOICE OF FLOWERS}

the new Colossus, with flowers a foot in diameter; still, in the average, it is a dignified plant and requires to be treated with the respect it confers on itself. It is not proudly self-confident; there is no swagger in its attitude; its gently bending head betokens a certain modesty, as well as pride; hence it should be allowed to enjoy the room and state that are conferred on the distinguished. It is neither king nor queen of flowers, but it wears the coronet of the aristocracy. And while it is not hardy, it has more life and more latitude than people know. I can show some handsome, healthy specimens in a New England village a thousand feet above the sea, and they kept on blooming last fall, after several sharp frosts had shorn and bedraggled not a few of the stouter blooms. It has a disagreeable habit of dropping its head on provocation that to an observer seems insufficient. A smart wind, a stout rain, a chill night, an interloping dog, will shake down a dozen fine knobs when it is in its prime. To remedy this tendency it is well to put it into rows, with some care for its support against the elements, either in the form of a wire net fence, or individual stakes to which we can 


\section{I T T LE GAR DENS}

tie the stems. Where stakes are used in a garden they should be painted green, that they may show as little as possible, and that they may agree with the vegetation when they are seen. If the dahlia never put forth a bud, its rich leafage would make it prized for a hedge, and against its green wall white flowers, such as the lily, ageratum, centaurea, dianthus, stock and nicotiana show clearly and beautifully. To allow for their spread of leaf the tubers of the dahlia should be placed two feet apart, but an effect of greater solidity is obtained if they are planted in a double row, and the front rank is opened so as to show that in the rear, thus:

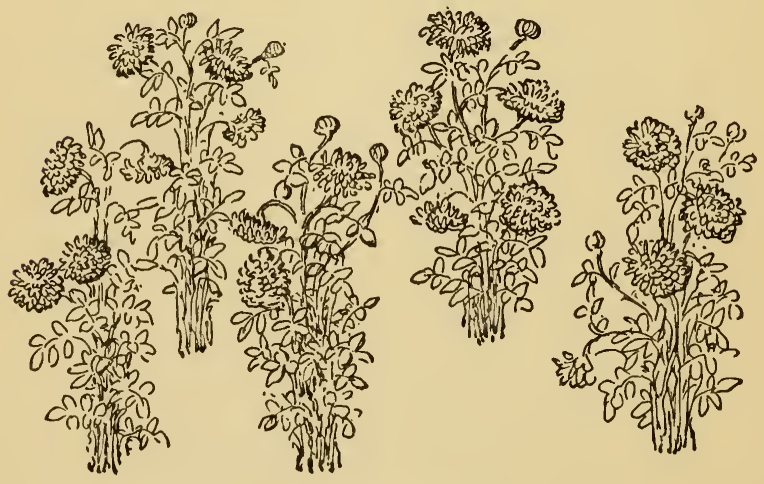

FIG. 25 . 


\section{CHOICE OF FLOWERS}

In such a case it would better insure their safety if a strip of wire net, such as is used for fencing poultry-yards, were extended behind each row, and the stalks tied to the wires, to hold them stiffly against the shock of wind and flood.

There is another good old grower of our grandmothers' gardens, that we can hardly overlook: the hollyhock. It is taller than the dahlia, coarser, weedier in its leaf, and as its buds open one after another, they shed their petals and go to seed, leaving long spaces of knobbed stalk, so dry and bare in appearance that one is reminded of the neck of a bantam after a fight with a bigger cock. Yet the round, sonsie face of this hearty, house-loving, wholesome rustic is full of cheer, yes, and beauty, too. In its white and pink aspects it is refined, even, but the crimson variety suggests the strength of sun and soil, and it seems to have good red blood running through its veins, in place of sap. I have found that the hollyhock will seed itself, under certain conditions, but its appearance is best guaranteed by planting the seed of it in early spring.

And speaking of color, we ought to make more of the zinnia than we do. It is a highly 


\section{I T T LE GARDENS}

useful bedding plant, inasmuch as it blooms generously and in a surprising number of hues. Doubtless its lack of odor and a certain harshness of texture and stiffness of carriage has to do with its lack of popularity, but its opulence of hue would make amends for more defects, if it had them. The flowers remain long, holding their color somewhat like the everlastings, so that they have an appearance of life after they have really faded. It is almost inconsistent, in our notion, that an herb so thick of leaf and petal should show such delicacy and even loveliness of tint. This flower avoids the blue, hence it accepts the red and yellow rays, and the variety of these tints that it exhibits is larger, I think, than that of any other flower which is equally confined in its range of form. It has not the limpid, brilliant white of the rose, the lily or the camellia, but a white of opaque and grayish quality, yet it grades down from this high light to a crimson, full and deep enough for the robe of an emperor, through a range of pale yellow, lemon yellow, gold yellow, orange, salmon, scarlet, pinkred, and hints at a purple mixture in magenta, solferino and a refined tone of lilac. These colors, 


\section{CHOICE OF FLOWERS}

varying though they do, can more easily be assembled in a single bed, because of their softness, than we can put together a diversity of most other species. The full reds will make the solferino cheap, hence it is better to sacrifice the one or the other, removing it to a distant patch, if you like. I do not understand the hostility to purples and purple-reds that is shown, and no doubt felt, by so many people. It is especially surprising that women should object to them, because they almost invariably gain in bloom from a touch of purple near the face. We have aniline dyes of these tints that are unpleasant, but, then, most of the anilines are unpleasant, and it is a good part of them that they all fade so quickly. The colors of the cineraria, which are ringed about the petal edges of that daisy-like flower, and which range from the blue of a June sky to deep and splendid maroons, magentas and solferinos, are superb-as pure and beautiful as sunset clouds and twilight skies in high altitudes, though differing in quality. We find these colors, too, and their modifications, in petunias, sweet-williams, centaureas, pansies and pyrethrums, and such tints are best grouped by them- 


\section{I T T LE GARDENS}

selves, or, at any rate, associated with green and white, and kept away from the shouting scarlet of the geranium and the assertive yellow of the marigold. Zinnias have occupied a group by themselves in my little garden, and have luxuriated in a light and pebbly soil, interspersed, to my sorrow, with relics of a glacial age, among which I shall not include tomato-cans and whalebone. They like water, and will eat a trifle of fertilizer and be thankful for it in the spring. Like other annuals, they are to be sown during the last of April, or a few days later, if the season is backward, and it may be well to relate here that the manner of planting such seeds is to stir the ground with a rake, or with a spade, if it has not been previously loosened, breaking up tough and clayey clods, and smoothing the surface; then, with a stick or trowel-tip, marking a tiny trench, half or two-thirds of an inch in depth. Into this the seed are sprinkled. With the stick or trowel flick the displaced earth back into the crevice, then crumble soil over the bed for half an inch or so, with the hands if the tract is small, with a sieve if otherwise. A light sprinkling with the hose may follow, using only the finest 


\section{CHOICE OF FLOWERS}

nozzle, so as to give a spray and not a shower; or, a little ducking from the watering-pot will serve. The object of this is not only to stimulate the seed, but to settle the earth about it.

Nearly all florists advertise packets of mixed seed. Artistic gardening is not encouraged by their use. If you buy a packet of zinnia seed, for example, you do not know, until the buds are actually opening, what you have put into the ground. By that time it is rather late to transplant, for even if the individual herb that you take from the soil is not injured in the process, you may seriously disturb the roots of its neighbors. If you find color inconsistencies and if you want to avoid cheap and glaring contrasts, you must dig up the plants, however, that are most belligerent in their blooming, and put them elsewhere. When there was no room in the beds for these intruders I have stolen out, in dark seasons, and transplanted them in vacant lots, hoping that they might prove a joy and astonishment for some wayfarer across those wilds, or for the children playing after school. One other item anent the planting of your garden, namely : begin weeding early. Don't tear up your choice things by 


\section{LITTLE GARDENS}

mistake, and there, you see, is another reason for marking the burial-place of the seeds, bulbs, roots and tubers. You will shortly learn to know the ragweed, pigweed, carpetweed, thistle and purslain or "pusley"-if you do not already know them, to your sorrow-and will have at them without mercy. The Spaniards have a wise old saw to the effect that it is never well to work between meals, so I pull my weeds before breakfast-sometimes. At all events, the earth is so softened by the night dews that these alien growths come out most easily while the soil is yet damp. If the bed is long, you will whip them cut with the hoe, but if small, and especially if it is thickly set with flowering plants, you must bend to your work and displace the intruders with a long, strong haul. Oh, yes: it's hard to do, when your hands are soft, your cheeks white, and your withers wrung, but there is a fine sense of brag, which you may speak or not, when you go in, sweaty, grimy, blistered, and you can not count that day lost in which you have toiled with a hoe, a spade, or a lawn-mower, as you may count some days in the hospital or on the stock exchange. 


\section{CHOICE OF FLOWERS}

Higher in the color scale than the zinnias are the nasturtiums, and in the make-up of a house garden we must not overlook these, its eminently cheerful citizens. They want the sunshine, and they soak it up and give it back in generous measure. Their color is really warm; it smacks of mustard; it lightens their very stems and leaves; they are even hot to taste, and they pickle the seed pods in the country, for a condiment. Yet, be it noticed that they do not assail the eye as a scarlet geranium will do, for the eye can not penetrate the petal of a geranium: it is as opaque as china, while the nasturtium is as translucent as colored glass. Moreover, the green of the nasturtium leaf is as high keyed as are the orange and yellow of the flower, so that there is a harmony of color well up in the treble. Even the soft and satisfying pinks and crimsons of this plant have an undertone of yellow. Theoretically you could arrange a disk or circle with a gradation from central warmth to marginal coolness, by putting nasturtiums in the middle, surrounding these with salvia, geranium, ruddy marigolds and poppies, these in turn with phlox, red poppies and the like; next a circle of deeper 


\section{I T T L E GARDEN S}

red, as in roses, grading into the lilacs and purples of bearçtongue, rock-cress, mourning-bride, closed gentian and so to the blue of pansy, fringed gentian, columbine, centaurea and ageratum-a rainbow that would be no longer a bow, but the completed circle. This is merely a fanciful arrangement, because these plants are not simultaneously in bloom, nor are they named with any regard for gradation in size, for where a circular bed is occupied by several varieties, the tallest must be in the center, the next tallest in a band or ring about it, and so, in successive diminutions till the low-growing ageratum, verbena, heliotrope, mignonette, candytuft, alyssum, alternanthera or portulaca forms the outer edge. In placing the tallest plants in the center we not only satisfy the desire for a formal yet simple arrangement, placing the conspicuous plants where they shall overtop the others while allowing them to be seen, but we minimize the shade they will cast, so as to give to each occupant of the bed an equal chance for prosperity with the stoutest. The nasturtium is useful as a bedding plant, also for borders, and as a vine; and if 


\section{CHOICE OF FLOWERS}

there are old stumps about the grounds that are too stout for pulling, they can be hollowed for eight or ten inches, and seeds or young nasturtiums can be placed there, in an ordinary soil. While they seem to like the drainage in a situation like this, and in porch- and window-boxes and hanging baskets, too, they are light feeders and prefer a sandy soil to one that is heavy and richly manured. This makes them easy to grow, and it may be the reason why they are not grown oftener, for we take most pride, if not most comfort, in what has cost labor and anxiety.

The geranium requires no introduction. Everybody knows it, even in the towns. It is common to both continents and is cheap, clean, vigorous and useful. It is long active, and you will force it to keep in blossom longer than it intended if you will pinch off the flower-stalks after they have begun to wither. This manner of producing bloom applies to numerous other plants as well. For the same reason that people buy yellow journals and see crimson dramas, they buy scarlet geraniums, forgetful that the plant has other hues, the pink, for example, and the full, clear red and white. Venders in the 


\section{I T T LE GARDENS}

town streets offer geraniums at five to ten cents a pot in the spring, so that it is hardly necessary to cultivate them through the winter in windowboxes and pots, though they are easily raised from cuttings and will grow in almost any kind of soil. One really excellent use for them is to fill ornamental receptacles, in parks, where assertive accents are desired. You may remember the half dozen big bronze urns on top of the orangery terrace, in Versailles, flaunting their blossoms above their lips, while the elaborate garden below is also lustrous with red clusters. Again, you may have wandered into some of those quaint inn-yards in France and England, where the ground is wholly hidden under cobbles or flags, and noted the relief to their desert stoniness which is gained from a single pot of geraniums at the door, or a ring of such pots about the well-curb, or a group of them in the corner where the hostler can spray them when he washes the wagons. Sometimes they are arranged in rows on low, broad walls, and in rural Normandy they prettily edge the porches of inns and cottages. But the scarlet geranium is a plebeian, and it brags of its loudness and vitality the 


\section{CHOICE OF FLOWER}

more when it is in refined and quiet company. There is but one way to treat it, in such a case: pot it and send it to the flower mission. It will be appreciated.

Grow fleur-de-lis, or iris. It is one of the early and affecting things of the year, with a sad, watery loveliness of texture, a faint fragrance such as we might expect from tears, if those liquids were not salt or bitter, and a reserve that is near to dignity. Tender as it seems, fragile as a form in tinted ice, it is yet hardy in our north temperate zone, and increases little by little every year until, in place of eight or ten stalks you have several square feet of fresh blades, and spike on spike of white, yellow, paleblue, lilac and rich purple flowers. The roots will be so matted that weeds can not intrude, but these roots should be separated from time to time, in order to gain room for healthy continuance and increase. The iris will grow on dry ground, in partial shade, or in ground that is almost marshy in summer and in the sun, but it prefers not to be wet in winter. I wish I could speak from experience as to the growing of the Japanese iris, or iris Kaempferi, but mine 


\section{I T T LE GAR DENS}

bloomed only once. It has large, handsome flowers, when they grow, but I found the oldfashioned kind the more reliable. They tell me that I should not have given a place to it in the usual garden-bed, but made a deep trench for it, filled it with old manure and rich loam, and watered it, no end. It is one of the disadvantages of rare strains that they require special treatment, such as you do not bestow on the contents of the old home garden, for most of the flowers I have named thus far ask little that is not given to their neighbors. The iris leaves can be cut off in the late fall, and after the frosts we will partly dismantle the garden, if only for appearance' sake, tearing up the annuals and the frozen plants, and housing such as will live through the winter in a sheltered situation, like the parlor.

Beside the iris there is another old friend that would be sadly missed if it were not in view from our windows: to wit, the pansy. This charming little blossom, with its quaint, innocent face painted on the petals, and its refined, elusive fragrance, is a development from the violet. The latter is not largely grown by us, 


\section{CHOICE OF FLOWERS}

because it shrinks from sight among its own leaves. The violet thrives best in the greenhouse, and those amazing violets of California, hawked through the land some years ago, guaranteed to rival the giant pansy in size and exceed it in perfume, paid smaller dividends to the confiding than some of the oil-wells in the same State that were advertised with increasing strenuosity the farther the promoter escaped from the base of operations. The pansy should be massed, its various colors by themselves, and it ranges through white, pale blue, lavender, yellow, orange and purple, its lowest note being a rich and velvety shade of the latter that casual observers speak of as black, albeit there is no black in flowers. It may be a fancy of mine, but it has seemed to me that the deeper the color in pansies, the deeper the odor. While it does not object to partial shade, an afternoon eclipse of the sun by a tree or building, it also stands the light, and if the flowers are picked often and straggling stems cut back, it will utter flowers the whole summer long. It often sows itself, and I know a bed of it that weathers temperatures of $30^{\circ}$ below zero, but it is believed to do 


\section{I T T L E G A R D E N S}

best if kept in a cold frame from early frost to early spring, then set out in a sandy place that has been well enriched rather than in a heavy soil.

Turning now to a different species-for we are considering customs and availabilities, rather than botanical relations-the peony presents itself, a healthy, rustic companion that suggests a country bride, a bashful, good-natured wench, prone to blushes and embonpoint. In form like the rose, suggesting it, too, in its short life, its prompt appearance, its thrift, its opulence, make it a glad arrival in every zone it decorates. Country gardens without "pineys" would be like old homesteads without wells, shade-trees and lilacs. There are white, pink and red peonies, and each shade is finer than the other, for all of them arrive when the world is otherwise lean of show, and the flowers are shy and small. The peony is a foretoken of the treasures soon to be squandered over the earth. It grows in almost any soil, but deserves to have its choice considered, and it prefers a light, but rich earth, fertilized once a year, and watered through the summer. In planting it is well to 


\section{CHOICE OF FLOWERS}

throw some old manure into the pit, and from that time forth it will care for itself. Its natural term of life is over twenty years. As the peony ends its blooming early, it is willing to share its bed with any plant of a later season and different form. We are to prefer harmony in forms as well as in colors, yet we are to avoid monotony, hence it is pleasant to find the bushy masses and decorative leaves of the peony in company and contrast with the green fountains of lilaceous plants, or with flowers of an upright or spiky habit, like foxglove, larkspur, nicotiana, the tall phlox, scabiosa or salpiglossis.

The prejudice that certain good people have against the petunia arises partly from its abundance; for if sunsets happened every hour, there are thousands who would not look at them any more than they do at present, and partly from the injury it suffers in being thrown into contact with vivid leaves and blossoms, that make its tender, purple tones weak, cold, even ugly. Petunias deserve a place to themselves, and I have seen beds of them, forty or fifty feet in their greater dimension, on a Long Island farm, that were like drifts of snow dashed with a 


\section{I T T LE G A R D E N S}

purple light of morning. While sensitive and costly plants may produce nothing but leaves, and few of them, the petunia is a sure bloomer in all kinds of soils, and it keeps at it all summer long. Its flowers wear white, pink-purple, bluepurple, a sober red and magenta, hence they are no partners for cannas, salvias, and especially for the geranium, coreopsis and ruddy marigold. Petunias are both double and single, but it is a defect in the former that their heads seem heavier than they can support, and they are as easily broken as dahlias are by rain, wind and gamboling pets, to say nothing of Mary Ann, whose destructive energies are greater than all the others. The single flowers are the handsomest, in so far as we are concerned with form, for the color range is the same in both. Either a light, dry soil or a rich and moist one serves for the raising of petunias. They will live in almost anything except a swamp or an alkali desert. Though they can be started in pots or boxes indoors, or in cold frames, I have never been disappointed in them when I have sown the seed out of doors in early spring.

Something of the prejudice that is roused I 86 


\section{CHOICE OF FLOWERS}

against the petunia, because of its color, is stirred against the poppy, for the same, and better reason, for the poppy, albeit a magnificent work of nature, splendid as the light that falls through cathedral windows, perpetrates an unattractive and opiate smell, likewise a gross inharmony, as you are likely to find if you raise it from mixed seed, for you will discover meek lavenders, sad purples and grave maroons side by side with roistering scarlets and gory reds, as if monks and bacchantes had been thrown into an enforced society. The poppy is tender and does not bear transplanting, therefore, if these chromatic riots annoy you, there is nothing for it but to look the other way, or else to boldly behead the offender - a thing you hate to do, for their sin is in their society, and not in themselves. Happily, in the case of discords, unhappily at other times, the poppy lasts but a little. Often it shakes its petals down in twenty-four hours after they have opened, leaving the seed-knob with its lethal content-its opium-swaying on a long, spent stem. The fleeting character of the poppy endears it to us the more, for we can not see the rain of its silken petals without a pang, and it is not color 


\section{I T T L E GAR D E N S}

alone that draws us to it, but its variety and grace of form. It is simple as we find it in the fields, a little red cup with rounded edges; and we hardly know for its relative that mass of white or pink or purple plume, lifted waist-high above the earth, and so full of life and light that we can not associate with it any property of sleep. Nor do we at once recognize as a member of the family the escholzia, a common variety in California, with delicate, finely divided leaves and low-growing flowers of yellow, singularly creamy, pure and tender. The escholzia will grow from seed planted in the fall, if it is well mulched, but the showy varieties come from seed committed to the earth at the end of winter. Such oddities as the horned poppy and the thistle-like poppy of Mexico do not please us in like measure with the splendid heads of the snowdrift, the cardinal and the fairy blush.

Sweet peas ought to be among our earliest considerings, both for their own sake and for their help in covering the fences. They must have strong cord, or wire, or strips of wire net to climb upon. The custom is to buy mixed seed and let them come up anyhow: white, pink, red, 


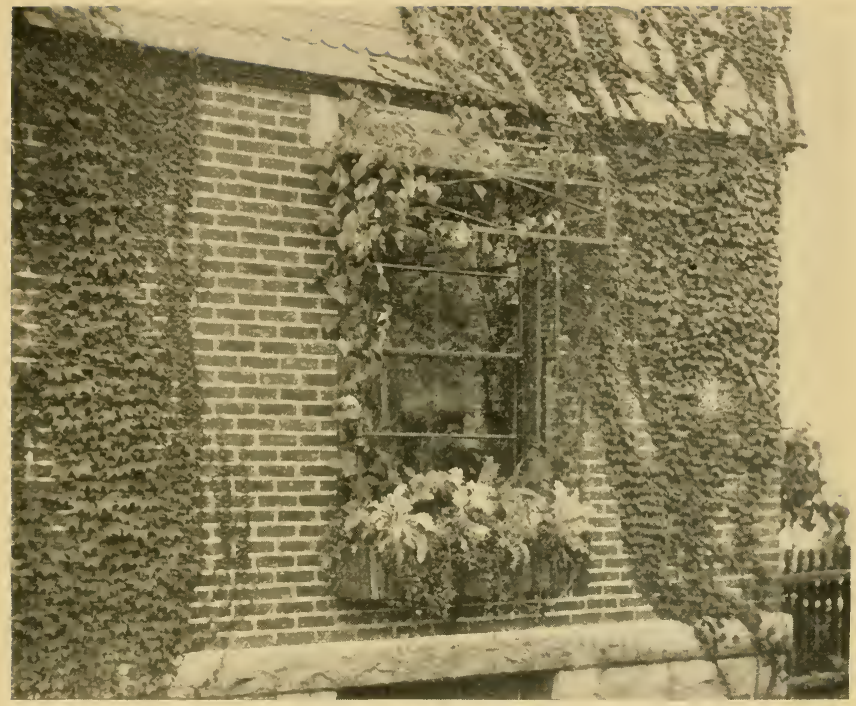

A WINDOW BOX AND AMPELOPSIS. 



\section{CHOICE OF FLOWERS}

purple, bronze, blue, faint yellow and mottled, all in a jumble; but it is easy to sow each color by itself, and you will admit the gain in this method, if, the next time they are in flower, you gather bouquets of them according to color: a blue to-day, a purple to-morrow, and so on. Let me add that by keeping the flowers picked you keep the vines well filled with flowers to pick. There is a paradox, if you like, but it is a fact. The seed may be sown in October at a depth of fully four inches, and to insure later flowering and take the place of any vines that may be frostkilled, there can be a second sowing in April. The plants are apt to come up thickly and will stand thinning. Some florists not only tear out a number of their vines, to give room for the greater expansion of those which remain, but in the late summer they cut all of them to a lowness of two feet, feed them with manure water, and start them in life all over again; but mine have always been such thrifty creatures that they have bloomed till frost, and after, needing no other attention than an occasional pruning. There is a pretty dwarf variety that calls for no wires or strings, for it is of bushy habit, and it therefore 


\section{I T T LE GARDENS}

endures closer planting and less pinching back. I confess to a dislike of pruning-amputation of the limbs of unresisting subjects; the thwarting of nature's intent; yet the garden is unquestionably the better for it. A florist will advise us not only to tear up and cut down sweet peas and poppies when they come up thickly, but will have us do the like for border plants, which we sow for thickness: candytuft, sweet alyssum, mignonette, portulaca, clarkia, larkspur and canary-bird vine.

Before the sweet peas have ceased from blooming we have the asters, with their heads of red, pink, crimson, white, pale-purple and darkpurple bloom. Their buds are due to open by the first of September, yet I remember that they are forced into flower at earlier dates-a circumstance brought to mind by the delighted remark of a woman at the Chicago fair, whom I heard calling to her companion, in one of the gardens, "O Samanthy! Look at the chrysanthemiums and Chaney oysters!"- the same signifying chrysanthemums and China asters. The asters carry themselves with reserve and primness, greatly different from the artistic slovenliness of 


\section{CHOICE OF FLOWERS}

the poppies, though less severe than the erectness of the zinnias and marigolds, and they rejoice in colors that are simply exquisite. Some of the rose-tinted asters have the glow of rubies. These are held to be tender, and are generally 'started in cold frames, yet they grow on bleak northern farms after spring sowing in open ground.

Chrysanthemums close the season. They resemble the asters in leaf, habit and mode of growth, but they have a wonderful diversity in form and a greater range of color. Fashion has neglected this plant of late, for fashion has its whims not merely in the matter of gowns and the drama, but in such affairs as mountains and bouquets. It has given over the chrysanthemum shows, that used to be regarded as society events no less than events of esthetic and scientific interest; hence, because it is less worth their material while, the florists exhibit fewer of the blooms in their windows. But no matter. We, who admire, may continue to cultivate it. Just as likely as not, we have fallen out of the habit of reading the society news, and have therefore failed to observe the significant announcement that Mrs. 


\section{I T T LE GARDENS}

Chuckleson-Jermynsides no longer drives in the park with a pug and chrysanthemums, but with a terrier and a bouquet of castor leaves and scarlet beans. And there are nurserymen in the land who go right along raising chrysanthemums as if nothing had happened to make them believe they shouldn't. They create new strains every year, and within the last quarter century they have sent specimens to the exhibitions that would have been an astonishment to our parents-big, fuzzy heads like those of football players, shapely globes of white, red, pink, magenta, yellow, orange, disks of crimson dashed with gold, open, sunny faces, knobs of close-set petals, nests of petals frazzled like those of the poppy, sober, formal, well-proportioned blossoms-in fact, there is no end to the variety. The big examples, that we see in the greenhouses of the dealers and showmen, are the results of unnatural stimulation and forcing; they have been treated to strong manures, and enlarged by disbudding; that is, the buds of the plant are nipped back to a single one at the end of each stalk, so that the strength formerly imparted to fifty blossoms is centered in half a dozen. Put your giant into 


\section{CHOICE OF FLOWERS}

the ground as soon as the petals have fallen, that is, if it is hardy, and next autumn, lo, a miracle! For instead of six or eight flowers something less in size than cabbages, here come thirty or forty of them, but all smaller than last year's buds; each a copy in miniature of the stately blooms of a twelvemonth ago. This increase in number and shrinkage in size and value but denote the reversion of the plant to its original type, the assertion of nature, and its reclamation of this, its offspring. In urging the chrysanthemum to feats and freaks of growth and color, shape and size, we sap its strength, and our indoor coddling makes it subject to colds and other diseases. Old-fashioned varieties are best to live out, for civilization weakens the subject. Hothouses are snares for both the vegetable and human victim: they so easily lead both into habits of luxury. Chrysanthemums can be started early in a hotbed, or later in the place where they are to grow. Those left out for the winter are to be cut down and thickly mulched. The showiest varieties are tender, and will require to be taken indoors and treated like other members of the family-a service which they re- 


\section{I T T L E G A R D N S}

quite by not putting out a single flower till fall.

With the flowers named in this list we can go a-garden-keeping. Not that the list is complete. One would require to take something like 700 pages out of Gray's Botany to make it so. Brief mention must still be made of the sunflower, that flaunts its banner of black and gold above the other color-bearers, and holds its station in any dry and sandy place; of the delightful marigold-I like even the bitter smell of itunfolding its gold-yellow, lemon-yellow, orange and brown-red in almost rash luxuriance: one of the easiest and surest of plants, and to be sown at the end of April in ordinary soil; the calendula, or pot marigold, with a more limited range of color but more refined quality-a tremendous lot of it you may count upon, in all varieties; the coreopsis, with its fringed petals of red and yellow, and its lank and infirm carriage when it is not artificially supported; the calceolaria, with its queer floral pouches dappled with red and yellow-a greenhouse product, not to be set into the yard till summer; the heady and luxuriant sedums, that like sand, rocks and coolness; and 


\section{CHOICE OF FLOWERS}

phlox, both Drummondii (the annual), lowgrowing, strangely starred and streaked, and the stout, tranquil perennial of our grandmothers' gardens, with its panicles of white, pink and red in solid colors. We ought to make a good deal of the begonia. If you have ever seen the beds of the tuberous species in the Harvard botanical garden, in Cambridge, you have seen a show as fine in its way as the shows of the chrysanthemums in town. Yet the flowers are not aggressively beautiful, and the plant is to be regarded rather for its foliage. In the greenhouse the begonia will attain a height of more than six feet, and it bears leaves of beautiful markings.

It is a pity that the primrose does not grow with us as it does in England. The Chinese primrose, that we raise in pots, is one of the first tokens of spring that florists offer, and it will keep in bloom for several weeks, they tell me, yet it is not for me to see it in flower after the first ten days in the window. It puts out false buds in bunches that never open, but wither down. Still, its fuzzy leaves are pleasant to see, and those transplanted early from the greenhouse will bloom generously. The red and yel- 


\section{I T T L. E G A R D N S}

low primrose and primula polyanthus, like the English cowslip, are hardy with us. The fuchsias, too: every one likes them, with their delicate, drooping bells of red and white, but it takes a year to raise them from seed, and they are seldom kept after their first flowering, though the fuchsia variegata is commended as a hardy kind that will live out of doors and take care of itself. The cockscomb, or celosia, is such a magnificent piece of color that it ought to be in every garden. Both the red and orange varieties are available in borders, though their hues are so strong that they are apt to dull the tints of milder colored flowers in the vicinity. It is a delicate plant, for all the bristling of its crest, and must be guarded against frost and dryness. There is much charm in our common balsam despite the habit of its flowers in clinging close against the stalks, and so showing less of themselves than if they jutted boldly into view, like zinnias. It is to be sown so soon as mild weather is assured. Not only is the color of the balsam pure and delightful, but the texture of its petals is singularly pearly, and the white is as tender as the white of a summer cloud. 


\section{CHOICE OF FLOWERS}

One of the flowers that always appeals to me by its modesty and grace is the bleeding-heart, with its festoons of pink, and its spring-like leaves. If they did not call its sister by so appalling a name as Dutchman's-breeches, quite probably we should elect that for the garden too, although it pleases one most when he finds it in the woods and among the ledges in May. The bleeding-heart is one of the long-lived plants, and is to be set into good soil so soon as the frost is out of the ground. Stronger reds than the bleeding-heart's we shall find in the canna, with its spikes of bloom and its huge leaves of refreshing green, and this plant is of especial use as a center for round beds, taking care not to put into the circles about it any flowers of a hue to be killed by its more assertive colors. The seed of the canna is so hard that it is proper to file a little hole in it and soak it in tepid water for a day be. fore planting. With canna in the center or in the back row we can employ the gladiolus as a neighbor for the inmost circle or the row next to the back, only there are pinks and magentas in the gladiolus that do not go well with the shriller reds of the canna. If standing at a distance from 


\section{I T T LE GA R D E S}

tall plants with straight leaves, the gladiolus is in good company if it is with rounder, shrubbier growths. The carnation and dianthus are popular in towns, but they are usually greenhouse products. In the garden they grow well enough in hot summers, but are apt to come up spindling, and they make less of a show, by far, than many plants of less estimation. Candytuft and sweet alyssum, with their tiny white flowers, are chiefly of use in borders, and are apt to grow scrawny and long. The alyssum appears to be the chosen habitat of a slithy grub that may have something to do with the patchy appearance of this plant. If you turn up the clusters you are pretty sure to find him in considerable numbers on the stems or on the earth where he has dropped. Better, to my mind, as a border plant, or as a filler for vacant spaces, is the portulaca, a lovable little member of the garden community, though related to purslain, which is one of the commonest of garden pests. In the first sowing of portulaca use seed rather liberally, and in places where the sun shines. After that it will sow itself, and you may look for it every spring. It exhibits white, pink, red, crimson and scarlet, 


\section{CHOICE OF FLOWERS}

the latter discordant with the others, but right enough for neighboring the geranium, the salvia and some of the cannas. More delicate, more charming than the strong-hued blossoms, is the salpiglossis, with its trumpets of buff and brownpink, and the scabiosa, or mourning-bride, which puts up heads suggestive of a chrysanthemum, or of an impossible cross between that and the bachelor's button. It occurs in white, yellow, purple and a so-called black, which is really a deep purple-crimson. In shape a kinship will be found to this flower in the gaillardia, a handsome and neglected species which likes the sun and a sandy soil. The bachelor's button, adopted by the German Emperor as his personal flower, and of soft blue, white, pink and purple, is agree. able in borders and masses.

The heliotrope and mignonette are entitled to a place in the garden because of the fragrance they give to it, but they make no such show as do the verbena, the stock, the sweet-william, the four-o'clock, the linum, the painted-daisy, or even the fuzzy little ageratum, and in considering these plants of woolly texture we are not to forget the uses of love-lies-bleeding, with its 


\section{I T T L E G A R D E S}

drooping tassels of crimson and its cloth-like leaves. One fills odd corners with this plant to advantage, as its line of grace relieves the angular setting of a fence junction and the uprights of a house or arbor. There are good words to say for Canterbury bells, foxglove, blazing-star, clarkia, columbine, and especially for the cosmos, with its fern-like foliage and its daisy-like flowers of red and pink and white. The cosmos stands six feet high, and ought to stand against a wall or fence, for it roots so lightly that it may be tipped over by a stiff wind. Its flower is delicate and refined and looks well in clusters for vases on the table.

Then, there are the plants with ornate leaves, the well-known coleus, the dusty-miller, the striped grass, the poinsettia, with its flaming bracts, the odd little houseleek and especially the alternanthera, a close-growing, small-leaved plant, that takes on glossy green or the autumnal red of oak-leaves. The alternanthera is almost the equal of box for borders and figures in the elaborate designs used in carpet bedding. I have not included any mention of this latter thus far, because, while it is more suitable for a small gar- 


\section{CHOICE OF FLOWERS}

den than for some of the grounds in which it is essayed, it is so extremely formal and difficult that for the amateur it is best left alone. The carpet bed reproduces as closely as possible the texture of a rug, and it is in these close-cropped and solid masses of vegetation that we find those horrors which are supposed to be the joy of Jake and Maggie in their walks through the parks: pictures, in plants, of eagles, harps, soldiers, ships and other devices so exceeding cute that you think of the man who invented them as sitting up with them all night to check the growth of a leaf here, a stem there and a flower in the other place, lest the sharp edging of a stripe or circle or curve be marred. To plan some of these foliage mosaics requires a geometrician, a gardener, a botanist in one, and the unceasing service of a laborer or an enthusiast is exacted to keep them in order after they have been planned and planted. Flowers growing as nature intended them to grow, in beds, to be sure, but unrestrained and helped, are of necessity more beautiful than plants collected into cities of their kind without elbow-room or breathing-room, tortured for a show. 


\section{I T T LE G A R D E S}

If our garden has a high fence or wall to keep off the winds and reflect the sunshine, there are many tropical or semitropical plants that will be willing guests of ours through the summerthe palms, the crotons, the velvety gloxinias, the huge elephant's-ear, the decorative castor-plant, the dracenas, the jasmin, and even those strange things of the air: the stag-horn fern, the tillandsia, and the orchids. We have swamp and field orchids that can be grown about our houses, provided they can have the soils and conditions of light and shade which they elect in the open, and the orchids of the Indies and Amazon can be kept through the summer in a warm and sheltered yard. Indeed, these have a stronger hold on life than is commonly supposed. The lycaste Skinneri and the cattleya triane cheered a winter for me by putting forth some beautiful blooms in a south window, where they had been hung against pieces of cork with a packing of moss about the roots; yet I have to confess that while they lived for several years, they never flowered again. The tropical varieties are not for domestic cultivation, at least, for more than a single season, except to that happy person who has a 


\section{CHOICE OF FLOWERS}

greenhouse. Wherein the orchid is not unlike the cactus. The plant children of the desert were a fad of mine, for a while. I spent more than I had a right to do in rare and odd specimens, and with one or two exceptions they died without flowering. The exceptions died just afterward. It was quite an experience to see them do it. And when you observe that in Arizona they live through everything, the heat of a rolling-mill, the drought of the desert, the chill of a northern winter, the calm of a cellar, the gale of an open sea, to say nothing of the preyings and nibblings of animals and insects, it is hard to understand why they should behave so ungratefully on our shelves and in our houses, but I suspect it is that they are treated too well, and have too much food and too much water. I found that cacti did the best in a rockery-to dignify a little stone heap by that name-for perched in niches on this monument, such moisture as they received ran quickly off, leaving them as dry as ever when the sun came out, and that is what they insist upon. They live a strenuous life, and when they have all that you suppose they have been asking, they sicken of a 


\section{I T T LE GARDENS}

surfeit and expire. Hot sunshine and little rain are their chief requirements, so the difficulty of keeping them contented in a cool and rainy land is obvious. Their bizarre forms, their hoary heads, bristling pincushions, snaky arms, tall candelabra, their melon shapes and their flat, leathery lobes are interesting, certainly, and experts persuade them to flower in surprising ways, but in the north country I would rather have a lily than a hundred cacti. Out on the plains in June it is a different matter. The bursting forth of rose and lemon-yellow cactus flowers in early summer is one of the shows of the world. Here are we in a yard and can not see it. 


\section{VII}

\section{THE WILD GARDEN}

I HAVE found much interest and satisfaction in the growing of wild flowers and wild animals in confined spaces, especially in stocking a yard that till then was bare of material. It was hard on some of the captives-much as if I had brought wolves and albatrosses out of the wild, and restrained them to a yard in town. Others, however, were thankful, and proved it by flourishing as they had not flourished in the meadows and by the roadside. In my strolls to the country I would carry a botany box and fetch it back filled with small plants, roots and cuttings, some of which died in disgust before the week was out. I also brought toads. In the first warm weather the new-born hoppers are out in the waste places, and I would gather up half a dozen and put them into the yard, to get ripe. In time, I thought, there would be toads enough in town to be of human service, but most of them have disap- 


\section{I T T LE G A R D E S}

peared, somewhere, somehow, and a new drove -herd-swarm-flock-what is the term?-is required to keep the garden free from insects. With their quick and slimy tongues they catch flies, beetles, grubs and other preying creatures; and then, too, they are company. It is amusing to see them swell, as if with indignation, when you pick them up and stroke their backs, and note the blinking of their beady eyes. They have a soft and chirr-r-ring call that may be heard on a still, warm evening as you loiter among your lilies and roses, so faint and tender that it gibes with the perfume and the coming of the stars.

There is another garden friend, too, that it is worth while to cultivate, at least, to avoid destroying: the ladybird, or ladybug. This tiny beetle with red wing cases spotted with black, the unthinking will crush, as they like to crush anything from caterpillars to elephants; yet it thrives on aphides, the slow-moving, slow-witted plant-lice that colonize on stems and leaves and suck the vegetable juices, giving them to the ants, their milkers, in tiny globules of fluid. And if you have a pool, and have failed to stock it with gold and silver fish or " pumpkin-seeds" - 


\section{THE WILD GARDEN}

a gross neglect-the dragon-flies will consume a few thousands of the mosquitoes that are in such case bound to breed in it. And you are never to kill a dragon-lly, or "devil's darning-needle," even if you do believe that it stings and that it will sew up your ears. In the south it would be proper to add to the ménage a lizard or twoharmless, pretty creatures, these, and I know people who keep snakes about their premises, because they feed on mice and possibly eat an insect now and again. Many birds have visited my reservation in town, mostly house-sparrows, that keep up an astonishing chatter even on their courtesy visits; but we have had robins, humming-birds, sea-gulls, night-hawks, and starlings are habiting some trees less than a quarter of a mile away. These starlings, which I hope are going to adopt us, are quiet, shy, with soft and flute-like speech, and prefer the security of high, remote places. They are with us from August to April, and make music at all seasons. A colony has occupied the Brooklyn water-tower for the past few years; there is a family in the trees behind the Alexander Hamilton grange, in New York, and in a certain prison that I know-re- 


\section{I T T LE GAR DEN S}

marks are not in order-the starlings nest and whistle in the vines and under the cornices. Add to the garden population, if you can, butterflies, moths and bees, and be kind to your little plowman, the earthworm, for without his burrowing and loosening of the soil it would pack like clay, and you would find it hard to grow so much as weeds. The amount of earth lifted in a single yard by these unseen helpers is, quite likely, a ton in a summer, and may be much more.

In transplanting wild flowers from their haunts to the home grounds, note the locality in which you find them, for you must afford to them a congenial habitat. Several kinds of ferns, as well as the glossy pipsissewa and wintergreen, will desire a woody shade, saxifrage will seek for niches in rocks, and butter-and-eggs requires the sun; the pitcher-plant prefers the bog, the camomile a sandy roadside; the ghost-flower, or corpse-plant, or Indian-pipe, as it is variously called, wants footing in old leaves, moss and roots, while the arrowhead must have water. It is impossible to collect every sort of wild flower into the city garden, because it is impossible in such a space to afford all the conditions necessary 


\section{THE W I L D G R D E N}

to a wide variety of growth. If you are determined to have certain exotics from the next township, you can provide for them, but in making them at home you destroy the home of your faithful and domestic flowers. For instance, I kept a skunk-cabbage, for the fun of the thing, and although it refused my blandishments after a little, it went far to convince me that I could have kept it going if I had watered and shaded it more thoughtfully. I think the neighbors regarded this as unholy, yet I never scattered its leaves over their premises. If, however, I had raised skunk-cabbages, the moistening of the soil would have made the place unfit for my sweet peas, honeysuckles, petunias and zinnias.

Dandelion, buttercup, goldenrod, mustard, butter-and-eggs, dog's-tooth violet, hawkweed, rattlesnake weed, cinquefoil, evening primrose, mullein, moth-mullein, St. Johnswort, star-grass, meadow-lily, butterfly-weed and oxalis I have raised in a city yard. The goldenrods were the pride of the place, standing so high as to conceal the moderately tall fence against which I planted them, and flaunting heads of bloom as large as a blacksmith's fist. The common white- 


\section{I T T LE GARDENS}

weed, which we call the daisy, I likewise cultivated with success, and an unexpected triumph was in the blooming of a pink lady's-slipper, or moccasin-flower, that I had dug on the edge of a ditch in the suburbs and replanted in poor soil, but watered generously. Of two buttercups, one flowered numerously, carrying hundreds of blossoms, while the other had fewer flowers and larger, because I had disbudded it, throwing its strength into the flowers that remained. I have a notion that the common wayside aster would act in the same way and produce blossoms nearly as large as the cultivated variety, if the buds were all pinched off, except half a dozen.

The yarrow is slowly getting its deserts by acceptance in gardens. It has an exquisite softness and fineness of leaf, which yields a pleasant nutty odor when crushed in the fingers, and it would be greatly esteemed were it not that it grows wild by dusty highways. One can not say so much for its flowers, for they are dull, grayish and inconspicuous, although the pink variety is as yet sufficient of a rarity to entitle it to garden use. The tansy, also, is a fresh and wholesome looking plant, with bunches of yellow 


\section{THE W I L D G A R D E N}

flowers that make a good appearance in the field, and why not in the garden? Suggesting the yarrow in its foliage and the daisy in its flower, is the camomile, another familiar of the country, but less worth while as a cultivated plant, because of its low growth and raggedness.

There is practically no end to the resources of the wild garden. The whole flora of a county, excepting the swamp flowers, can be represented in an estate that is large enough and that has some variety of surface-rocks, mold, sand and shade. We can begin our season in that garden early, with the violet, liverwort, starflower, blood-root, rue-anemone, May-apple, the trilliums, Solomon's-seal, spice-bush, the rhodora, the wild pink, the showy orchis, the polygala and wild geranium, and carry color and fragrance through the months till the snows begin to sprinkle over the last gentians, Joe-Pye-weeds, everlastings, goldenrods and asters.

The place for a wild garden is at a remove from the house, if the space available for formal gardening is small. It is better to separate the cultivated from the wild, not that the former learn any bad habits from the other, but that 


\section{I T T LE G A R D N S}

the savage plants are heedlessly insistent in the matter of scattering their seed, and escapes from the wild garden into the cultivated are much more certain than escapes of the civilized from the places set aside for lilies and roses. So soon as a wild flower has established itself where it is not wanted, it becomes a weed, and is liable to the treatment accorded to interlopers. But while it is with us from choice, let us be good to it, plow the ground in which it is to stand, water it in dry seasons, even weed it when ugly and unwelcome growths threaten to overrun it or crowd the daintier residents. A surfacing of manure in the spring and of mulch in the fall will be as well appreciated by the wild flower as the tame one, and it will prove its appreciation by increased growth and livelier color. The wild flowers can be collected into beds and treated in the same manner as the geraniums and petunias, or the seed can be sown broadcast over prepared ground. And it is now possible to obtain the seed of wild flowers from mercantile growers, whose offer of it must surely be based upon an increased appreciation of natural beauty. 


\section{VIII}

\section{SHRUBS}

ALL large forms are to be used with caution in small grounds. We must give our yard to what we deem the best, and in the country, where we are surrounded by woods, we will not try to construct a forest at our doors. If we can deceive ourselves into thinking that the yard is a cosmos, well and good; but the effect will be rather desperate if we try to make it one. If a brook runs through it, flowing between steep banks, bowered with alder, elder, willow, woodbine and clematis, setting the birds a-singing with its gurgle, and opening glades that invite us from the world to listen for that message of more than mortal consequence that winds and waters always seem about to speak, yet that ever eludes our understanding, we are privileged, indeed. Only, as there may be a mile of delightful wilderness beyond our confines, and no lilies, dahlias or chrysanthemums in all that distance, is it not better 


\section{I T T L E G A R D E N S}

to make our garden in the spot we have cleared, than to restore our clearing to the wilderness?

The use of shrubs, however, does not commit us to any such attempt. Many of them are available and admirable for yards and other small spaces. They are needed, like the vines, to cover unsightly fences, to give variety, interest, dignity and beauty to the prospect. In a large garden they can be massed into thickets, or made to serve as backgrounds for beds, and it is an effective use of them to have dense plantations of flowers in careless windings before these thickets, the flowers rising directly from the lawn without the usual path before them, thus:

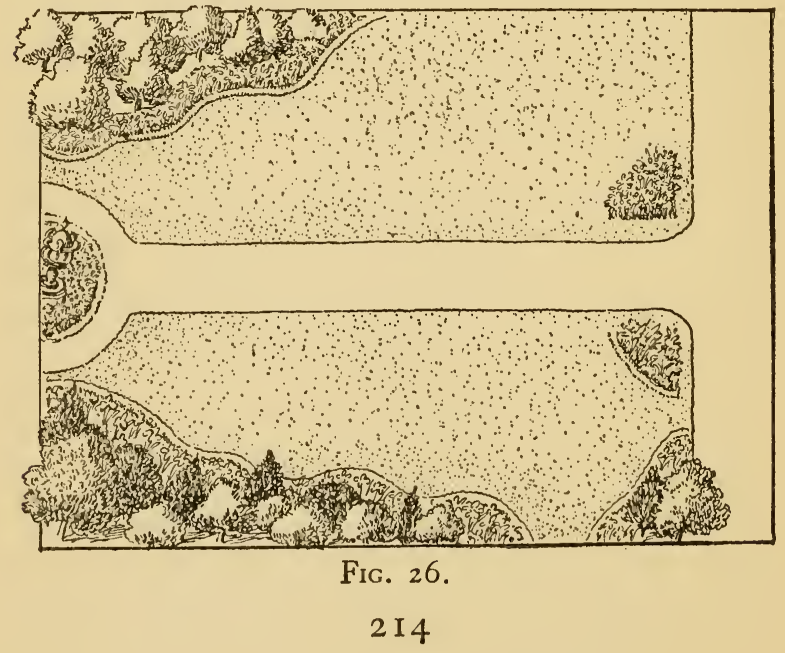




\section{S H R U B S}

By following a contour rudely indicated by the shrubs themselves, formality is reduced to a minimum, though we can add the two little beds and the half-circular space at the beginning and end of the path for the cultivation of smaller, more delicate plants than we would entrust to a summer-long tussle with the grass, and with the shade cast by the thicker vegetation. Beside the ferns there are many flowers which can be relied upon to bloom in shade.

It is claimed that shrubs and trees are now safely transplanted at any time of the year, but the fall is the best season for the work, as in spring the sudden interruption of the sap flow, made in lifting them, retards their growth, if it does not imperil their lives. A tree unsuccessfully replanted is never strong and satisfying, and generally dies young. The shift should be made as quickly as possible, and the ball of earth be kept about the root until the bush is ready for its new place. The hole must be large enough to receive the roots outspread, and if it is found that any of them have been injured in transit, it is advised that they be cut off cleanly, with a sharp knife, above the break. When set into 


\section{I T T L E G A R D E N S}

its new lodgment, earth is to be sifted over the roots, then garden mold shoveled on and well tamped down, by boot-heels, if other and less usual implements are not convenient. It is seldom that heavy manuring is required, because the best shrubs for garden use thrive on soil of coarser texture than is needed by herbaceous plants, and root more stoutly for their own livings in a dry season. If flowers are planted near, they should still be at such a distance as to avoid entanglement with the bushes, for in such case they would steal one another's substance and the growth of each would be hindered. Severe and yearly pruning is believed to injure the flowering property of shrubs, and I have never done more in that direction than to cut out old or gnarly branches. The new growths will have to be fought steadily, unless it is desired to extend the range of the plant. Black currant and lilac, especially, are determined to possess the premises, the former sending its runners under ground to arise at unexpected places six feet away. It is fiercely and insistently reproductive.

The lilac does not put out these skirmishers, but advances in solid line of battle, sending up 


\section{S H R U B S}

from the close neighborhood of the central trunk a multitude of lesser stalks, and massing so densely as almost to exclude the light from the earth beneath it. If these suckers are not promptly trimmed off, or hoed out of the earth, the difficulty of removing them is much increased, for in a few months the wood grows so tough as to resist the hoe. These shoots will rollick upward into the body of the bush, and so it interferes with itself, lessening the growth of its flowers and starving such leaves as can not gain the light. If early separated from the bush and set out in new ground, the suckers will become healthy bushes of themselves, in a few seasons. The lilac is one of the elements in the rural picture that a country boy will not dismiss from his memory. He recalls the white and the pink-purple clusters that flourished in scores, sometimes in hundreds, over the bush that stood at the door, and that are still blooming in lonely spots among the hills where men's eyes rarely see them, for the houses they beautified are gone and the farms deserted. He recalls their fragrance in moments of reverie that happily come to him in the moil of town. He remembers 


\section{I T T L E GAR D E N S}

the pitcher of new-cut thyrses that adorned the table when the minister took tea with the family, or when lunch was set out for the matrons and spinsters of the sewing-circle. He recalls the groups of lilacs in the school-yard, and those that cast a shadow at the gate of that sacred place of shadows: the village cemetery. And so remembering, he plants a lilac before his city home, or has it in his yard. We see more of lilacs in town than of any other shrub, yet we see not half enough of them. Over a score of varieties are offered by the nurserymen-white, purple-rose, red with a faint blue cast, full purple and purpleviolet. This shrub will stand neglect, but that is no reason why it should have it. What is worth room on one's premises is worth affectionate care. Like other plants, the lilac asks a drink in thirsty weather, it needs occasional pruning, and is none the worse for an annual loosening of the soil about its roots.

Useful in backgrounds is the weigelia, or diervilla, a bush of loosely spreading habit, but shapely, and bearing trumpets of ruddy purple, pink, red and white. This shrub is said to come from Japan, where it grows from three to six 


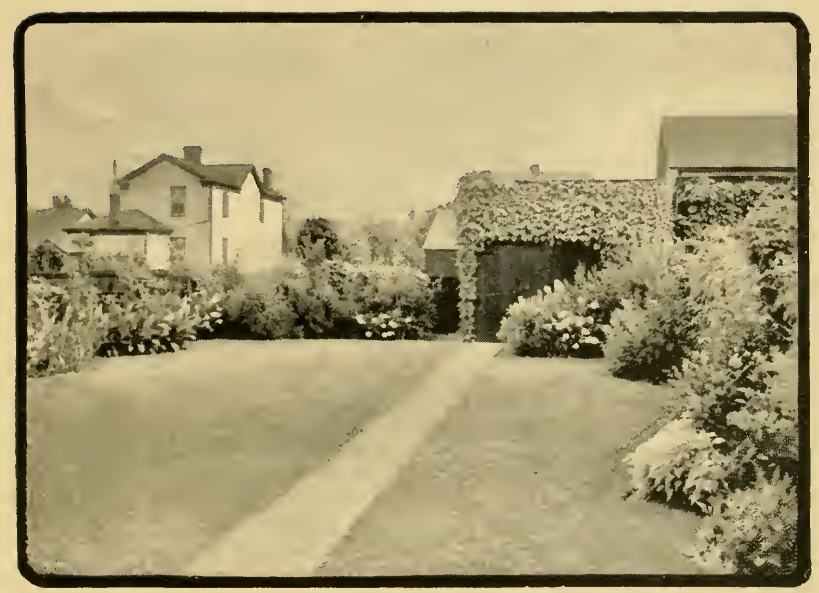

A PLEASING VISTA. 



\section{S H R U B S}

feet in height, but I am sure that one in my yard has attained a height of eight feet-at least, that its branches would measure that if they were straightened. It is a free bloomer, the flowers lasting from the end of May to mid-July. It loses a branch now and again, not from disease, but apparently from age, and these dead limbs will be amputated, of course. It also appreciates a little fertilizer, yet it grows easily, and in any common soil.

I doubt if the azalea will stand our winters; at least, the cultivated sort, bearing red and white flowers, is sensitive, and the wild azalea, with its watery buff, yellow and salmon blossoms makes so much less of a show, in the north, that it has yet to win its place as a garden plant; but its congener, the rhododendron, deserves admiring consideration. This splendid shrub, most glorious of all spring vegetation, its thickets bombarding the hills with flashes of red, pink, purple and white, is a winter ornament, because its leaves are always green and glossy, and it pushes forth its buds in the fall, so that all through the winter it seems as if an hour of sunshine would set it flourishing; but after its season 


\section{I T T LE GAR DENS}

has passed and it has begun its summer rest, it is apt to grow dull and ragged; hence the planter should make the most of it, and group it by colors, where possible. These clusters are not to be crowded, to be sure, for the plant requires room to develop itself to its full height, and if it finds a place to its liking it becomes a tree. Such clusters are large for the town yard, and are better apportioned to country estates, especially for covering a hill slope and concealing spots of poverty or ugliness at the bottom. The laurel, with its waxen cups, is a contemporary of the rhododendron, as to bloom, and suggests it at a distance. It is sometimes used to fill out masses of shrubbery in which the latter bush is dominant. As foliage the andromeda is also to be viewed with favor, and its white spikes sprinkle it with snow at about the time the bigger rhododendron is lavishing its bloom. Specialists tell us that all of these shrubs, azalea, rhododendron, laurel and andromeda, which are American in origin and come to their best with us, succeed in a peaty soil, or one in which old leaf-mold, rotted turf and a modicum of stable manure have been mixed. In England they re- 
fuse to thrive in a limestone district, but I have found thickets of healthy laurel, or kalmia, among the limestone hills of the Hudson; that is, there are lime quarries within a mile, or less, of these plantations.

Of other shrubs mention may be made of the barberry, which grows to a height of five feet, takes on autumn color, produces yellow and red flowers and scarlet berries, and is useful where a thin hedge is required; also, the English and Spanish brooms; the Japanese quince; the dogwood, which, like the magnolia, is to be considered rather as a tree; the snowball; the rose of Sharon; in fact, the list might be extended to a hundred, but several of these are less available for small gardens than the shrubs first mentioned, because of susceptibility to frost, sprawling growth, undue size, failure of bloom, or finical disposition respecting soils and treatment. Any seedsman, nurseryman or practical gardener will advise the amateur when problems arise respecting yard area, shade and light, herbaceous allies and character of soil.

The box and privet are especially to be mentioned, however, because of their usefulness in 


\section{I T T LE GAR DENS}

hedges and borders. Box is of a small leaf, tough stem, compact growth, is at home in all soils and can be raised from cuttings, which are to be removed at the end of warm weather, say, in September, and placed in the shade for rooting. Some new strains have been announced, in which the leaves, instead of showing the deep green that lasts all winter, are variegated with white and yellow. These gold and silver shrubs are serviceable when tubs or pots of vegetation are required to margin a walk or lawn, or to sentinel an arbor or a door, or to encircle a pool. The potted box will grow to a height of four or five feet, and it looks quite as well as the yew or cedar that has attained no greater altitude. The same may be said of the privet, which makes a neat appearance as a single plant, but serves its best function as a hedge. Privet is said to grow scrawny in some parts of the country, but in the North and East it can be teased into a hedge as compact as that of box. The proper treatment of it is to cut it ruthlessly in the early spring of its second year-cut it to within a foot of the ground. This will cause a number of strong new shoots to emerge from the central stalks, taking 


\section{S H R U B S}

the place of stalks that have been shorn away, and the effect of this thick growth near the root is to make the shrub so dense that dogs, cats and poultry will not pass through. I frequently walk by a city yard that is shut off from the street by a row of privet which has been allowed to grow a dozen feet high. It is thin below; hence it gives no concealment, but it attains arboreal importance in its outspreadings. And, apropos, the severity of a hedge, when there is a long reach of it, can be broken by a few evergreens behind it, or a few potted plants on the lawn or walk before it, or by both. Spruces and hemlocks show well against the solid green of privet, and they can be grown in tubs, where they are to be manured and watered, like deciduous growths.

If one has large grounds he should not plant a hedge where it will obstruct a pleasing view, or cut across a generous vista. Indeed, nothing should be planted in an open space, if it will have the effect of breaking that space into inconsequent and disconnected areas. If we can not plant in masses, at least we can plant in rows. In the orchard we plant in rows for convenience' 


\section{I T T L E G A R D E N}

sake, and if our fruit-trees flank the house, it is an easy matter to open the aisles before our doors and windows, and so give reach of the eye into comforting distances.

As centers in plant groups or geometrized plans, or as bits of form and color in dull spots, we may use, beside the shrubs, the conifers, the Japanese "blood-leaved" maple, compact and colorful, the hazel, the weeping birch, the weeping ash, and the small varieties of weeping willow and weeping elm, but the usual city yard is too small for a tree that has a lateral spread of more than ten feet. We must consider proportion, especially in the furnishing of a place that custom has made disproportionally small for our needs.

And in summer we can set out our palms and rubber-plants, which have been adorning the dining-room or parlor, sinking the pots into the beds, to secure them against the wind, keeping off the insects and cutting away the dead leaves. They will enjoy our tropic summer, but must be taken in promptly when cool weather threatens. Every one knows the rubber-plant, with its broad leaves of polished green; and there is no better 


\section{S H R U B S}

palm for domestic cultivation than the kentia balmoreana. Palms are all more or less addicted to the pesky little scale insect, which must be washed off and picked off at least once in a week, yet the palms usually enjoy as good health as the insects. 


\section{IX}

WATER IN THE GARDEN

THERE is no question as to the charm which is added to a garden by a little water-an eye of blue with brows of rush or tropi: grasses if you please, though it is better for a small pool to be rimmed plainly with cement or stone and to show all of itself it can. If only a couple of yards in diameter there is an impression of crowding when vegetation is placed in it; at least, anything more than a single plant, and for that plant I would choose our common pondlily, white and fragrant, an ivory star with central rays of gold. If we are able to widen the basin, however, we can add the water-poppy or the water-hyacinth, which flowers in summer in our northern climate, and which, in southern rivers spreads in such weedy luxuriance that government has to spend large sums yearly to clear the channels for navigation. It has no root in 


\section{WATER IN THE GARDEN}

the ground, but lives on the water, as orchids do on air. If our little lake is a dozen feet or more across, we can have a tinted variety of pond-lily, the pale yellow, or the pink, to live with the white. If it is shallow and has turfy banks, we may have a growth of bamboo, or canebrake, or papyrus, at one side. The latter, which in its form is like a miniature palm, is doubtless the most tractable of the grasses for a small pool, as it does not often exceed four feet in our latitude. This is the grass that gave to the world the earliest material for the impressions of pen and ink, and from the word papyrus we keep the name of paper, to this day. There is something foreign in its aspect and it brings into our home ground a vision, howsoever faint, of the land of the Pyramids, the sunrise land of mystery.

Other possibilities for the boggy shore or shallow water are the pickerel-weed, arrowhead, snakehead, marsh-marigold, pitcher-plant, showy orchis, and, near by, where their roots will be well moistened, the daffodil, iris, cardinalflower and forget-me-not. There is a tendency to put too much into the water itself, and quite 


\section{I T T LE GARDENS}

obscure its surface, which has a sky-reflecting value and beauty of its own. We must crowd our water-garden no more than we crowd our garden of earth, or our air-garden in the orchid house. And the tendency is not only to put in plants which are too large for their setting, but too many varieties. For pools of any size, however, we are always safe in the use of the pondlily, and it will reach up to the surface from a depth of five or six feet, holding to the bottom by its long, ropy stalk. The Zanzibar lily in blue, purple and a particularly lovely red is an introduction from the East which is much used in large grounds and parks. The Egyptian lotus and yellow lotus are large for yards, and to reach their best estate they require not only room but artificial heat, except in our southern belt.

If the pond is natural it has its own basin, which can be widened or lessened by digging or filling, but if artificial, a bog must be prepared for it, and this can be of sods and pebbles, if it is a large and informal sheet of water, or if it is a mere bowl it can be cemented or bricked and provided with an overflow-pipe, which needs a wire 


\section{W A TER IN THE GARDEN}

net at the orifice to keep the goldfish from going through, and the vegetable refuse from choking it at the traps or bends. If cement, mortar, asphalt, paint, stains or other artificial substances are used in the lining of the basin, the water should stand for a week, with frequent changes, before fish or plants are introduced. And while a fountain adds to the appearance of life and certainly to the beauty of a water-garden, it will imperil the vegetation if it is fed from a very cold spring, like many that we find among the mountains. Pond life is partial to warm, quiet water. For this reason, too, it is best to delay planting under water till summer has fairly set in, and the nympheas, or pond-lilies, may then be placed in the bottom soil, or packed into a sunken box filled with old manure, old turf and earth. The advantage of using a box, which should be a yard square and a foot deep, is that it can be removed when cold weather begins, for so soon as the green is gone and the supply-pipe is plugged for the winter, the box becomes unsightly. After planting, the water is to be gently admitted, the surface rising by slow advances, about a foot in a week, so as to disturb the plants 


\section{I T T L E G A R D E N S}

as little as possible, but if this involves so much roiling of the water as to distress the fish, or if, in the absence of fish, mosquitoes threaten to breed in the stagnant pool before it rises to the level of the overflow-pipe, it is better to let in the water at once. Useless to consider the victorias, with their immense leaves, on which an adult may stand in safety, for those giants require either a tropical climate or a greenhouse. Many of the floating plants, too, the water-hyacinth, water-poppy, water-snowflake and parrot'sfeather, spread so fast as to threaten the lives of the lilies.

If one lived in a town like Amsterdam, or Syracuse, or Chicago, he could have a watergarden that should be more than a stone basin, and if he lived in no town at all, but near the bank of a river that was clear and not subject to spring freshets, he might more easily have the like. It could be grown to lilies and lotus, or it could be kept clear for bathing. In the ruins of St. Pierre, the fated town of Martinique, I found several marble-lined pools, one of them about twenty feet long, and I asked myself why in our equally superheated coast towns we could not 


\section{WA TER IN THE GARDEN}

have their duplicates, for summer use, at least; for we have to admit that in winter a water garden is a dreary place, for usually it is necessary to draw off the contents of the pool in order to prevent the swelling volume of the ice from cracking the cement. So here is the shadowing forth of a dream, but you are to pretend that it is midsummer when you study it:

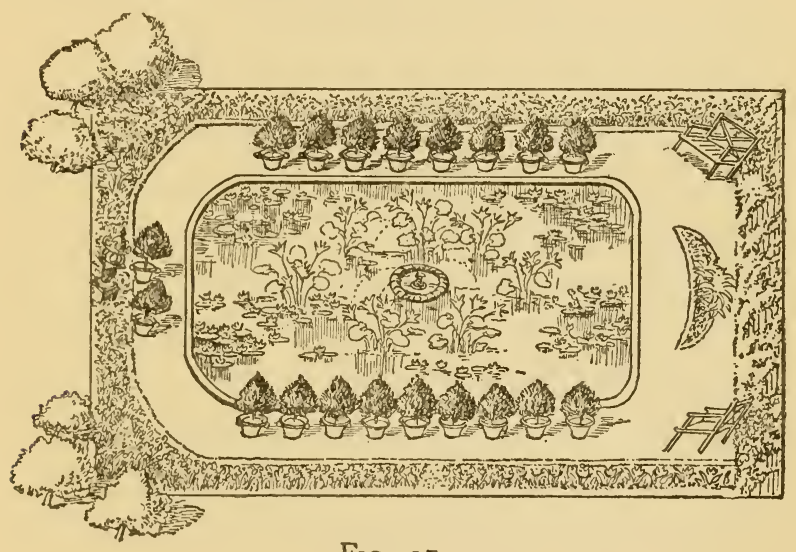

FIG. 27.

To use an inconsistency, this is a lazy man's resting-place, (lazy men having no occasion to rest, merely idle,) and you are to imagine that it is surrounded by vine-covered walls; that as you sit on one of the benches at the near end, 


\section{LITTLE GARDENS}

you see reflected in the water mirror the marble god, athlete, or what not who occupies the pedestal among the shrubbery at the farther; that the basin with its goldfish is bordered by cypresses, yews or bays in tubs; that above the benches extends a trellis covered with vinesgrapes, if you want them, for everything is free in fancy-land; that from the nearer bed rise the color and perfume of such plants as will live in partial shade-godetia, lily-of-the-valley, musk plant, pansy, anemone, bluebells, phlox divaricata, shooting-star, St. Johnswort and such ferns as the maidenhair, lady-fern, oak-fern, cinnamonfern and the noble sword-fern, which in many a darkened valley in New England grows headhigh; for in the country one may take ferns from the fields for his lighted garden, and there are ferns by the million in the woods which he can abstract for his shady corners. You are also to see that roses, lilies and iris gleam among the foliage along the farther wall; that noble oaks and elms, or a group of solemn pines overlook the ground and checker it with transparent shadows; that birds nest in those trees and make a morning and evening melody; and apart from 


\section{WATER IN THE GARDEN}

the sough of wind and the voices of birds and insects there are no sounds but the harping of water-drops, as they fall from the central fountain. Here, remote, alone, forgetful of the rudeness of the world, living with his books, his science, his art, his music, his flowers, will sit the recluse and keep his mind warm and serene with loveliness.

Some such a yard as this could also be contrived for seashore cottagers whose premises go down to the border of the deep. If they dwelt on Cape Ann, or the Maine islands, it would not be difficult or costly to blast out a hollow in the native rock, fill it with salt water, by means of a ditch, or pipes, and in this sheltered lagoon to introduce, besides the usual finned swimmers, starfish, jellyfish, squids, octopods, anemones, lobsters, crabs, shrimps, sandworms and mollusks, as well as the sea-mosses that sway so softly when the water moves. The pool would be a veritable place of wonders, and you would lie in a boat or on a board above it, studying its strange forms by the hour. Have you sailed across the sunken gardens in the glass-bottomed boats at Santa Catalina? If so, you need no 


\section{I T T LE GARDENS}

urging to add an ocean pool to your estate. Though your flower-garden were a tropic blaze of color, you would much neglect it to watch the mysteries of the deep. 


\section{$\mathrm{X}$}

DECORATIVE MATERIAL

THE decorative material available for a yard is not large. At least, it should not be large in bulk, and it is not in variety. Passing a shop in the metropolis, the other day, I found along the walk before it huge capitals of columns, wellcurbs from Italy, stone benches, marble lions and heraldic monsters, and observed that they were offered for sale as fitments for gardens. They will go to New Jersey and will help some rich man to pretend that a fine crop of Roman temples and Renaissance palaces has just gone to seed on his premises. We may advocate formality with a grace, for it is only humanness; but there are situations in which it is bombast, or hypocrisy, to strew our ground with what obviously belongs out of it. If we will have them in small spaces, then fonts, benches, termini, capitals, well-curbs, short columns, bases and their like are better than large figures, inasmuch as 


\section{I T T LE GAR DEN S}

they dominate the ground less arrogantly, and the ground shows for itself.

I suppose there is no law against the use of Italian wells in American parks, any more than I suppose there is a lack of Americans who can design American wells for Italian parks, but these objects, weighing a ton or two-I am not speaking of the designers now, but of their wellcurbs-require large surroundings and backgrounds, not of shrubbery alone, but of stately trees; in short, the setting of a large landscape. If we have an important tree in the city yard we shall always live in the shadow, for there will be no room for anything else. Yet a large oak, or even a maple, would be no more out of place on the spot where we are supposed to dry the clothes than a big piece of sculpture would be. A statue, unless it is small and simply pedestaled, demands room. It subordinates to itself a space of three times its greatest dimension. It can be exhibited in city squares and parked spaces with surroundings of flowers and ornate leafage; indeed, it should have this footing in the naturalbeautiful, so long as it is out of doors. In a small garden we can not dignify a work of art 


\section{DECORATIVE M A TERIAL}

by floriculture to the degree it may deserve, for it must serve as a part in a decorative scheme; otherwise the surroundings will be such as to create a ridiculous contrast between the statue and the setting. Imagine, if you please, a marble Apollo or a bronze Mercury with a whitewashed fence behind, and the clothes hung to dry before it. Yet, if we removed the clothes and substituted a wall, which comported in solidity with the material of the statue, the effect would be beautiful, provided, to be sure, that in our composition we had subdued all to that statue: given an important position to it at the back or corner, massed flowers about it, arched it with vines, made reflections of it in a fountainbasin, maybe, led toward it with walks and repeated its upright attitude in vines and potted trees, so that it would not stand stark and unsupported. Here is a scheme wherein the garden is so subordinated, yet as there are four points, either of which could be made focal, the figure might with equal fitness be placed at $A$, or $B$, or $C$, or $D$. If placed either at $A$ or $C$, something might be added, for balance' sake, since the plan is formal, at the opposite side-a 


\section{I T T LE G A R D E N S}

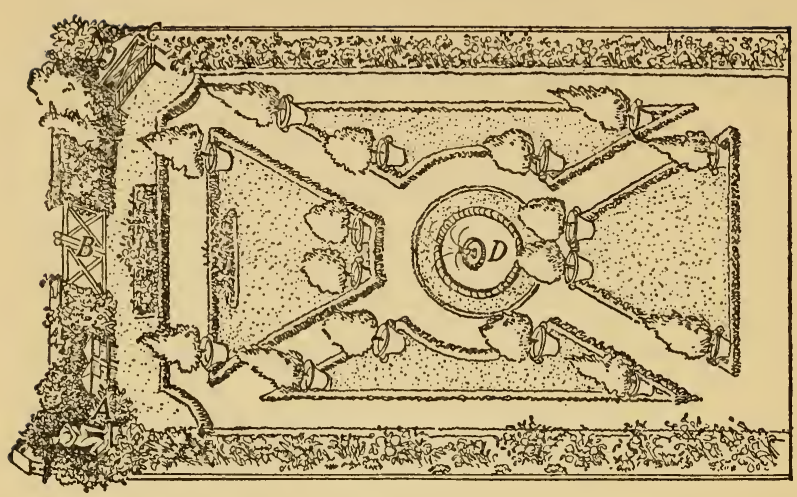

FIG. 28.

bench, a font, a small rockery : nothing of exactly equal size, not anything in kind, because two pieces of sculpture would be too many for a single yard, and it would be carrying formalism to monotony to repeat one corner in its opposite.

In this device are two vistas, and we require something at the end of each. If the statue be placed at $B$, then the semilunes that flank it, and that end the paths, can be filled with flowering shrubs of some size and showiness, not forgetting that the statue itself will require greenery, for white and green make the one brisk contrast that is esthetic. Its pedestal will be high enough 


\section{DECORATIVE M A TERIAL}

merely to lift it into view, a couple of feet sufficing for a life-size figure. Statuary is raised on lofty bases only when it is desired to make it "tell" at a distance. It would be the twelvefoot height of absurdity to put a twelve-foot pedestal under any figure with which we sought to ornament our yard. Mounted in that fashion its place would be the front of a capitol or city hall. And mind, I am rather insisting that while there may be a statuette there shall be no statue, unless there is a wall for a background, and we do not build many walls in this country. I can remember hardly a dozen on the island of Manhattan, that surround estates of consequence, though I do recall some ancient defenses of the sort in its upper districts, now gone to rack and ruin, through the cutting of new streets and subways, the building of elevated roads and viaducts, the appropriation of adjacent fields for tenements, and the incoming of that disturbing horde which defies the blandishments of soap. With such a canvas as any one of these estates offered in its best day, what pictures might not one create upon it! May I draw one here, of what I would have in this garden of my fancy? 


\section{I T T L E G A R D E N}

It is but rudely indicated in these lines, of course, but they will help to explain my meaning:

I will suppose the space, then, to be forty by a hundred feet. It shall be commanded by a house in which the architectural lines will not be extinguished by a mask of brick, but will show timber beams and braces, latticed windows and vines reaching above its first story. The wide, low windows giving on the yard shall often be left open, for the view, the perfume and the coolness. The ground shall be quite surrounded by a brick wall eight feet high, for this is my cloister of evening meditation. There is plenty of world outside, and I shall see it often, but here I withdraw from it. A brick wall is cold and trite? So it would be if we left it at that, merely; but there are to be a stone coping and borders of half bricks affording a strong and gritty edge to the construction; there is to be a paneled base; there are to be a dozen terra-cotta insets with conventional ornament, like an acanthus-leaf, or any such, while at $C$ there is to be an alcove a foot or more deep and three feet high, to contain some rare exotic, or perhaps no more than an urn of stone. Should I have more land, the wall 


\section{DECORATIVE M A T ERIAL}

will be pierced at $B$ by a gate leading, I hope, to fair acres and pleasing rambles; possibly to some quiet stream or wood of mystery. This gate should be of heavy wood, and either stained green, with hand-wrought iron hinges, or, if the wood were old enough to have taken on a ripe and quiet tone, it would be left of its natural color. The wall should be almost hidden by vines: sweet pea and morning-glory, where the sun shone, honeysuckle, clematis, woodbine, and at the back two or three trees should throw an afternoon shade over the ground. On top of the wall at a farther corner, or, better, built into the masonry, would be a bird-house where, if possible, some starlings should be domesticated and protected. I don't know whether these softvoiced musicians eat bees or not, but if bees disagree with them there should be a hive somewhere among the shrubbery, near the back, that their tuneful hum might be added to the restful whispering of the leafage and the tinkle of water, which would spray from a little fountain in the pool at the center of the yard. The long beds on either side of the walk should be filled with flowers, perennials like roses and lilies, beside 


\section{I T T L E G A R D E N S}

zinnias, marigolds, nasturtiums, Canterbury bells, foxgloves, pansies, dahlias, asters and chrysanthemums; and where the flowers assembled thickest, in the farther left corner, I would place my statue-an ancient bronze with a fine patina, in which the hue soberly yet richly varied through yellow green to purplish olive, but if I could not have my bronze, then a figure in marble, solid and restful in attitude, a pagan goddess or a Christian saint: no hurlers of spears, or wrestlers, or boxers, or martyrs, or dying soldiers, but a figure that stood its ground with the firmness of a caryatid. And it should not be the prettiness of yesterday, freshly polished in an Italian studio-shop, but an old piece from Pentelicus, its snow softened to cream, its hard shininess gone, its neat chiseling of draperies blunted by contact with a sometime admiring, sometime forgetful world. At the opposite end of the cross-walk would be an easy bench, not an affair of roots glued over a framework of carpentry, the product of a town factory, but an honestly fashioned seat of hewn timber, circling or half circling the tree trunk, if the tree were big enough to justify and support it. One thing 


\section{DECORATIVE M A TERIAL}

this bench would not be, and that is, a cast-iron copy of a so-called rustic seat. A chair or bench might be made of iron, yet be artistic, therefore, honest, and it might fit into a garden scheme. Maybe if this were suggested to a Japanese designer he could produce one. But why should the iron pretend to be wood, any more than wood masquerade as iron? Let us have homely frankness about us, rather than supposedly ornate sham-for, as a matter of fact, sham is seldom ornate. I do not admire those beds, designed for New York flats, that are folded up by day, when they pretend to be innocent ice-chests, pianos and sideboards. Every observer knows them for designing and insomnious frauds. I do not admire chromos that affect to be real oilpaintings, done by hand, nor Philadelphia rugs that make believe to have been woven in Shiraz, nor coffee that grew on chicory, nor wine composed of dye and vinegar, nor milk compounded of chalk and water, nor any other thing that goes through the form of being better than it is. Sand in its place is useful, even beautiful, but its place is not inside of the sugar-bowl. And so I would avoid in and about the garden all those pretenses 


\section{I T T LE GARDENS}

in which we observe a gross and ridiculous disparity of material and appearance, or of function and effect. I would not, for example, suspend a gypsy kettle from three sticks and plant heliotrope therein, making believe to boil this herb over a slow fire which causes the blossoms to emerge, in place of smoke. It is quite permissible to string a hammock in the angle of the wall. Your naps and contortions will not be exhibited to the neighbors.

The arms of the Maltese cross, to which you will trace some likeness in the plan, are lawns, and these should be leveled by persistent rolling and kept as green, fresh and unmixed with anything other than grass and clover as sound seed, fresh water and a diligent war on weeds can make them. Every weed removed gives so much the more space for grass, and in time a carpet is formed into which interloping thistles, dandelions and ragweed find it increasingly hard to penetrate. For association's sake I would edge the gravel walks that intersect the ground with box, and keep it in borders not over twenty inches high, always neatly trimmed, and green all through the year. At the points of the lawns 


\section{DECORATIVE M A T E R I L}

should be placed tubs of oak with iron handles; for here is legitimate use of metal, and those vessels should contain thick-growing little trees or solid-looking bushes. If all the trees were hemlocks, yews and spruces, so much the better, as they repeat and intensify, yet harmonize, the upright lines of the statue and the house sides, and increase their altitude, if there are not too many of them; for an upright by itself is taller than in company, just as Niagara, because of its breadth, loses the height which would be readily apparent if we took any ten-foot span of the cataract, and closed it in with rock. And these tubbed trees should be darkly, serenely green, standing with an air of some fixity, like the statue and other fitments, and contrasting pleasantly with the large and fluent forms of the maples, magnolias, elms, lindens or gingkos that overhung the wall at the back. If these taller, rounder trees grew really outside of the walls, it would be pleasanter than if they grew within, for the space is so small that it would be a hardship to sacrifice it, even for a tree, especially when all the picturesqueness of the latter could be effected without putting the stem on the hither 


\section{I T T LE GARDENS}

side of our boundaries. The space indicated for trees in the plan could be filled by such bushes as the syringa, lilac, laurel, weigelia and the larger or taller growing roses. The pool should be of clearest water, led from a mountain spring, and containing a few lilies-only a few, because one would wish to look at the fish swimming beneath the pads, for if there were no fish there would be mosquitoes, unless there were a current so strong that those pests desisted from laying their eggs on the surface, in which case it would be too agitated for the successful raising of lilies, and the fish might grow discontented, also.

If there were no pool and no statue, a clump of tall, feathery grass, such as we have brought from the South American pampas, or an urn filled with the Kenilworth ivy, a fast and easy grower, would serve as decorative points-hubs for the radii of our composition. Or, at $B$ we could train an arch of roses or other vines, preferably an arch of wood or bamboo, yet permissibly of wire net, for this wire tells what it is made of, and does not pretend to be porcelain, sandalwood or mahogany. And if there is a vase, let it be of stone or pottery, not of cement; this not 


\section{DECORATIVE M A T ERIAL}

alone for appearance' but for endurance' sake. Cement has its uses, as in the casing of the pool, but the making of gravestones, urns and statuary from this material is forbidden by the law of esthetics. Have you ever looked upon a statue of cement? If so, it is too solemn a spectacle to forget. Don't have anything in the garden that is molded by machinery, unless it may be drain-pipes. Let the work show the touch of the human hand, and let it be a duplicate of nothing that exists elsewhere. Yet, if there were a city ordinance that compelled me to have a statue in the yard, and I found after a search through my garments that I had not the price of a Venus of Milo in marble-a discovery sure to fill me with astonishment-I would doubtless buy a figure of plaster; for the Italians make faithful and artistic copies in this cheap medium. They are good enough for our museums and art schools, and ought, by that token, to be good enough for gardens. $\mathrm{Hm}$ ! They are not rained on, in the art schools. But if you do set up a plaster image, paint it first, just to take off its raw whiteness. Use a cream-colored or yellowbrown pigment, or even a pale green, and if the 


\section{I T T LE GAR D E N S}

figure is chipped, cover the chipped place with another touch of the color.

I think I have not mentioned Japanese lanterns as garden possibilities. They are alien enough, to be sure, yet they are quaint and decorative, and more modest than the importations from Italian palaces and convents with which so many owners of palaces try to foreignize the landscape of New York and Massachusetts. I am not speaking of those paper lanterns, gay and pretty ornaments, familiar to lawn-partiesluminous flowers of the night - but of the stone and metal inventions that are used in and about the temples of Japan. They stand on pedestals, somewhat like binnacles on shipboard, they have overhanging roofs like pagodas, and they may contain lamps or candles. Their little windows, softly shining through leaves, suggest the comforting lights of home. These devisements are works of art, and while there is a similarity in their construction, each is an individual conceit; that it is which makes them art. Much gilded, trifling, insincere ornament is made for garden use, but it behooves us to be content with simple things and let our walks through little kingdoms 


\section{DECORATIVE M A TERIAL}

teach constancy and simplicity. My garden should have those things that are sweetly familiar, unexcitant, of conceded loveliness.

The best of the garden, however, is what you put into it, rather than what comes out of it. It is the satisfaction of your tastes, and the bettering of them, the thought and sentiment you express in planting and gathering, the innocence and quiet of mind that you take to the seeding, trimming and watering, that are the real rewards. In time the garden comes to mean a part of yourself, just as your pictures and your library are a part, and it will be modest or bombastic, delicate or vulgar, trivial or sincere, ingenuous or artificial, according as you possess those qualities. As it flourishes it may disclose a broad mind and generous nature, or it may prove in its dryness and ill feeding, a habit of pelf and a grudging of care. If it is worth while to have a garden at all, it is probably worth while to have one that will humble the neighbors; but this does not imply mere show : it implies content with your work and enjoyment of what you have. I often wonder if content is not one of the lost arts, at least, among the residents of towns. I 


\section{I T T LE G A R D E N}

believe it has a close relation to the art of gardening. I ought to have said, the craft of gardening, for if we look on this employment as an art, our pleasure in it may be the higher, yet I. fear it will be the narrower. We can treat the flower-bed as we would paint a picture or shape a statue; we can make it poetic and endow it with fine and sensitive qualities, and we should do so; but it is best as a broad and intimate human expression. We may not approve a garden, but if the motive in creating it has been sincere, if it indicates a love of the beautiful and a reverence for life, we must respect it, for in doing so we respect its maker.

THE END 


\section{TWENTIETH CENTURY TEXT-BOOKS OF BOTANY.}

\section{By JOHN M. COULTER, A.M., Ph.D.,}

Head of Department of Botany, University of Chicago.

Plant Relations.

A First Book of Botany.

$12 \mathrm{mo}$.

Cloth, \$1.io.

"Plant Relations" is the first part of the botanical section of Biology, and, as its title indicates, treats what might be termed the human interests of plant life, the conditions under which plants grow, their means of adaptation to environments, how they protect themselves from enemies of various kinds in their struggle for existence, their habits individually and in family groups, and their relations to other forms of life-all of which constitute the economic and sociological phases of plant study.

Plant Structures.

A Second Book of Botany.

$2 \mathrm{mo}$.

Cloth, \$1.20.

This volume treats of the structural and morphological features of plant life and plant growth. It is intended to follow "Plant Relations," but may precede this book, and cither may be used independently for a half-year's work in botanical study.

\section{Plant Studies. An Elementary Botany. I 2 mo. Cloth,} $\$ 1.25$.

This book is designed for those schools in which there is not a sufficient allotment of time to permit the development of plant Ecology and Morphology as outlined in "Plant Relations" and "Plant Structures," and yet which are desirous of imparting instruction from both points of view.

Plants. A Text-Book of Botany. I 2mo. Cloth, \$r.8o.

Manv of the high schools as well as the smaller colleges and seminaries that devote one year to botanical work prefer a single volume covering the complete course of study. For their convenience, therefore, "Plant Relations," and "Plant Structures" have been bound together in one book. under the title of "Plants."

Analytical Keys to Flowering Plants. 12mo. Limp Cloth.

Northern States. By Professor Coulter. $25 \mathrm{c}$.

Pacific Slope. By Prof. W. L. Jepson, University of California. $45^{\mathrm{c}}$.

Rocky Mountain Regions. By Prof. Aven Nelson, University of Wyoming. $45 \mathrm{c}$.

These Keys may be used with any text-book of botany, but they have references to the text of Professor Coulter's books.

A Laboratory Manual of Botany. By Otis W. CALDWELl, Ph.D., State Normal School, Charleston, Ill. 5 oc.

D. APPLETON AND COMPANY,

NEW YORK. BOSTON. CHICAGO. LONDON.




\section{GEORGE H. ELLWANGER'S BOOKS.}

\section{The Garden's Story; or, Pleasures and Trials of an Amateur Gardener.}

With Head and Tail Pieces by Rhead. I6mo. Cloth, $\$$ I. 50 .

"A dainty, learned, charming, and delightful book."-New York Sun.

"One of the most charming books of the season. . . This little volume, printed in excellent taste, is redolent of garden fragrance and garden wisdom. . . . It is in no sense a text-book, but it combines a vast deal of information with a great deal of out-of-door observation, and exceedingly pleasant and sympathetic writing about flowers and plants."-Christian Union.

"This dainty nugget of horticultural lore treats of the pleasures and trials of an amateur gardener. From the time when daffodils begin to peer and the 'secret of the year comes in to mid-October, Mr. Ellwanger provides an outline of hardy flower-gardening that can be carried on and worked upon by amateurs. . . Nor is the information of this floral calendar confined to the literary or theoretical sides. 'Plant thickly; it is easier and more profitable to raise flowers than weeds,' is a practical direction from the garden syllabus."-Philadelphia Public Ledger.

\section{The Story of My House.}

With an Etched Frontispiece by Sidney L. Smith, and numerous Head and Tail Pieces by W. C. Greenough. I 2 mo. Cloth, \$1.50.

"When the really perfect book of its class comes to a critic's hands, all the words he has used to describe fairly satisfactory ones are inadequate for his new purpose, and he feels inclined, as in this case, to stand aside and let the book speak for itself. In its own way, it would be hardly possible for this daintily printed volume to do better."-Art A mateur.

"An essay on the building of a house, with all its kaleidoscopic possibilities in the way of reform, and its tantalizing successes before the fact, is always interesting; and the author is not niggardly in the good points he means to secure. ... The book aims only to be agreeable; its Jiterary flavor is pervasive, its sentiment kept well in hand."-New York Evening Post.

\section{In Gold and Silver.}

Vith Illustrations by W. Hamilton Gibson, A. B. Wenzell, and W. C. Greenough. I2mo. Cloth, \$2.00. Edition de Luxe, on Japanese vellum, \$5.00.

"One of the handsomest gift-books of the year."-Philadelphia Inquirer.

"After spending a half-hour with 'In Gold and Silver,' one recalls the old saying, "Precious things come in small parcels." "-Christian Intelligencer.

"The whole book is eminently interesting, and emphatically deserving of the very handsome and artistic setting it has reccived." -New lork Tribune.

D. APPLETON AND COMPANY, NEW YORK. 


\section{BOTANY.}

\section{Morphology of Gymnosperms.}

By John Merle Coulter, Ph.D., Head of Department of Botany, The University of Chicago, and Charles James Chamberlain, Instructor in Botany, The University of Chicago. Illustrated. 8vo. Cloth, iss pages. \$1.75.

The Gymnosperms, as the most primitive seed plant, are of special morphological importance, and are very inadequately presented in current general texts. This book brings together and organizes the widely scattered results of investigation. It is not. a compilation, but a combination of published results, supplemented and guided by several years of original investigation. The authors have sought to disentangle and simplify a confused terminology which has heretofore obscured a very consistent morphology. The essential morphology of the great groups is considered in detail, the fossil forms are represented in the light of recent important discoveries, the comparative morphology of the group as a whole is discussed, and the part closes with chapters on phylogeny and geographic distribution. The illustrations are numerous and the majority of them are original. The book is addressed to special students of morphology, of the evolution of the plant kingdom, and of the paleobotany.

D. APPLETON AND COMPANY,

NEIV YORK.

BOSTON.

CHICAGO.

LONDON. 


\section{BOTANY.}

\section{Morphology of Angiosperms.}

By John Merle Coulter, Ph.D., Head of Department of Botany, The University of Chicago, and Charles James Chamberlain, Instructor in Botany, The University of Chicago. Illustrated. 8vo. Cloth. 348 pages. \$2.50.

This volume has grown out of a course of lectures accompanied by laboratory work, given for several successive years to classes of graduate students preparing for research. It seeks to organize the scattered amount of material so that it may be available in compact and related form. While careful attention has been given to citations, so that the student may know the groups that have been investigated and be put in touch with the original papers, the work is in no sense a compilation. The ground has been traversed repeatedly, for several years, by various members of the botanical staff and by numerous students, and their results have served to check current statements, as well as to contribute no small amount of new material.

No attempt has been made to present the details of floral structure, so fully described by the earlier morphologists and taxonomists, since they are easily accessible in numerous texts. It has rather been the intention to present the general ideas involved in the alliances of first rank, so that principles rather than details may be prominent.

D. A P PLETON A N D COMPA NY, NEW YORK. BOSTON.

CHICAGO. LONDON. 


\section{By WILLIAM C. EDGAR.}

\section{The Story of a Grain of Wheat.}

By Williay C. Edgar, Editor of "The Northwestern Miller." Illustrated. Cloth, \$I.00 net; postage, ro cents additional.

The story of wheat is a marvelous one, and is here told with all the interest of a narrative. A short chapter dealing with the character of the berry itself, and its enemies, diseases, and pests, precedes its earlier history from its probable birthplace in the valley of the Euphrates to its cultivation in modern times. Then follows a review of Britain's supplies and requirements, with a brief review of the fields of France, Germany, and other European countries. India is considered as a wheat producer, and Russia's ability to compete in the world's markets is discussed.

This book will merit the attention of the general reader who may not be practically interested in wheat and its products, because of its direct and lucid narrative, telling the story which appeals to all human kind-the story of man's long-continued struggle for plenty and his final triumph over savagery and want. Its special and exceptional value, however, beyond its intrinsic worth, will be to those who are concerned directly or remotely in the making of flour, its handling and sale, or its manufacture into bread. By these it will be welcomed as a book of record and reference, an exponent of the fundamental principles of their particular industry and an impartial history of its achievements, written by one who is in full sympathy with its broader and higher aspirations.

D. A PPLETON AND COMPANY, NEW YORK. 


\section{WHERE TREES GROW, THERE HUMAN SYMPATHY LINGERS.}

\section{Practical Forestry.}

A Book for the Student and for all who are practically interested, and for the General Reader. By Prof. John Gifford, New York State College of Forestry, Cornell University. Illustrated. 12mo. Cloth, \$r.20 net ; postage, 12 cents additional.

The recent establishment of the Bureau of Forestry at Washington, the steps taken in different States for forest protection, and the movement for national forest reservations which began a few years since, are tangible evidences of the increasing interest in a subject of immediate and general importance. The need of popular information regarding this subject, presented in a form comprehensive and practical but interesting, has prompted Professor Gifford to prepare this book. It is based upon actual experience as well as scientific knowledge, and also upon an acqaintance with the needs of the many different classes of those interested in the forests for economic or partially sentimental reasons.

The author explains simply and clearly the points of practical interest relating to soil, growth of trees, their care, their relation to the water supply, the evils of wholesale cutting, and the practical value of judicious selection. He places before the reader, in his sketch of forest distribution, a most interesting picture of American woodlands, which emphasizes the importance of a source not only of wealth, but of safety, much neglected in past years.

Aside from the value of this book to special students and to those interested in the forests for economic reasons, the work is full of suggestions to owners of country homes and to all who care for nature.

D. A P PIETON A N D COMPANY, NEW YORK. 


\section{OLDEST OF THE ARTS, NEWEST OF THE SCIENCES.}

\section{Practical Agriculture.}

By Charles C. James, M. A., Deputy Minister of Agriculture for Ontario, formerly Professor of Chemistry at the Ontario Agricultural College. American Edition, edited by John Craig, Professor of Horticulture in the Iowa Agricultural College. With numerous Illustrations. I 2 mo. Cloth, So cents.

This excellent book shows how easy, interesting, and practical the teaching of agriculture in common schools really is. It imparts a knowledge of the science of Agriculture as distinct from the art-that is, a knowledge of the why rather than of the how. This science consists of a mingling of chemistry, geology, botany, entomology, physiology, bacteriology, etc. The foundation principles of these subjects have been included and their applications clearly and suggestively shown.

Professor James gives his subject the broadest interpretation. Agriculture is for him the cultivation of the soil for food products and any other useful growths of the field or garden. It includes tillage, husbandry, farming in general, and any industry practised by a cultivator of the soil, as breeding, rearing, dairying, etc.

\section{Governor JAMES A. MOUNT, Indianapolis, Ind. :}

"I would that such works were in every farm home. They would give the farmer a broader view of his vocation. He would view it as an art, a science, a profession, and not as mere drudgery, requiring manual labor instead of mental activity."

\section{A. W. RANKIN, Inspector State Graded Schools, Minneapolis:}

"I think James's 'Practical Agriculture' is the hest book I have seen on this subject. I heartilv approve of its purpose, and shall urge its use wherever an opportunity offers."

D. APPLETON AND COMPANY, NEW YORK. 


\section{By F. SCHUYLER MATHEWS.}

\section{Familiar Flowers of Field and Garden.}

New edition. With 12 orthochromatic photographs of characteristic flowers by L. W. Brownell, and over 200 drawings by the Author. I2mo. Cloth, \$I.40 net; postage, I 8 cents additional.

The new photography's revelations of nature have found perfect expression in Mr. Brownell's remarkable pictures. 'The beautiful series included in this new edition will be appreciated by every one, and prized by students and nature-lovers.

\section{Familiar Trees and their Leaves.}

New edition. With pictures of representative trees in colors, and over 200 drawings from nature by the Author. With the botanical name and habitat of each tree and a record of the precise character and color of its leafage. $8 \mathrm{vo}$. Cloth, $\$ 1.75$ net; postage, 18 cents additional.

Mr. Mathews has executed careful and truthful paintings of characteristic trees, which have been admirably reproduced in colors. The great popularity of his finely illustrated and useful book is familiar to nature-lovers. The new edition in colors forms a beautiful and indispensable guide to a knowledge of foliage and of trees.

\section{Familiar Life in Field and Forest.}

\section{With many Illustrations. I2mo. Cloth, \$1.75.}

"A very attractive bojk, which contains a mass of useful information and curious anecdote."-San Francisco Chronicle.

"The book is one that is apt to please the young naturalist, as it is not overcrowded with scientific words of sucli dimensions as are usually a bugbear to the young student. The information is given in a pleasant way that is attractive as well as instructive."-Minneapolis Tribune.

\section{Familiar Features of the Roadside.}

\section{With I30 Illustrations by the Author. I2mo. Cloth, \$1.75.}

"Which one of us, whether afoot, awheel, on horseback, or in comfortable carriage, has not whiled away the time by glancing about? How many of 11s, however, have taken in the details of what charms us? We see the flowering fields and budding woods. listen to the notes of birds and frogs, the hum of some big bumblebee, but how much do we know of what we sense? These questions, these doubts have occurred to all of us, and it is to answer them that Mr. Mathews sets forth. It is to his credit that he succeeds so well. He puts before us in chronological order the flowers, birds, and beasts we meet on our highway and byway travels, tells us how to recognize them, what they are really like, and gives us at once charming drawings in words and lines, for Mr. Mathews is his own illustrator."-Boston Fournal.

\section{APPLETON AND COMPANY, NEW YORK.}




\section{BOTANY.}

\section{The Plant World: Its Romances and Realities.}

A Reading-Book of Botany. Compiled and Edited by Frank Vincent, M.A.. author of "Actual Africa," "Around and About South America," etc. (Appletons' Home-Reading Books.) Illustrated. I 2 mo. Cloth, 60 cents.

\section{The Origin of Floral Structures through Insects and Other Agencies.}

By the Rev. George Henslow, Professor of Botany, Queen's College, London. (International Scientific Series.) With numerous illustrations. I 2 mo. Cloth, \$1.75.

"The object of this work is to endeavor to refer every part of the structure of flowers to some one or more definite causes arising from the environment taken in its widest sense. To some extent the attempt must be regarded as speculative; and, therefore, any deductive or a priori reasonings met with must be considered by the reader as being suggestive only."-THE AUTHOR.

\section{The Oak: A Popular Introduction to Forest- Botany.}

By H. Marshall Ward, M.A., F.R.S., F.I.S. With 53 illustrations. I $2 \mathrm{mo}$. Cloth, \$1.00.

As so often happens in the study of science, we have in the oak a subject for investigation which presents features of intense interest at every turn. It will be found that the story of the oak as an object of biological study is at least not less fascinating than its folk-lore.

D. APPLETON AND COMPANY, NEW YORK. 


\section{BOTANY.}

\section{A Contribution to Our Knowledge of Seedlings.}

By Sir John LubBock, Bart. 684 illustrations. 2 vols. 8vo. Cloth, \$10.00.

The germination of plants is certainly not the least interesting portion of their life history, but it has not as yet attracted the attention it deserves. It seems surperfluous to say that the subject has received a thorough and careful treatment by Mr. Lubbock, who has contributed a most valuable work to the world of science.

\section{The Origin of Cultivated Plants.}

By Alphonse de Candolle. I 2 mo. Cloth, $\$ 2.00$.

The knowledge of the origin of cultivated plants is interesting to agriculturists, to botanists, and even to historians and philosophers concerned with the dawnings of civilization. This book treats of the origin of almost double the number of species belonging to the tropics and the temperate zones that were treated of in the author's first work on geographical botany. It includes almost all plants that are cultivated, either on a large scale for economic purposes or in orchards and kitchen gardens.

"Though a fact familiar to botanists, it is not generally known how great is the uncertainty as to the origin of many of the most important cultivated plants. .... In endeavoring to unravel the matter a knowledge of botany, of geography, of geology, of history, and of philosophy is required. By a combination of testimony derived from these sources M. de Candolle has been enabled to determine the botanical origin and geographical source of the large proportion of species he deals with."-The Athencum.

\section{APPLETON AND COMPANY, NEW YORK.}




\section{BOOKS ON BOTANY.}

\section{A Study of Leaves.}

By Mary B. Dennis. Small 4to. In colors. Paper, 50 cents.

The first laudable effort to popularize a science the technical terminology of which forms perhaps the chief obstacle to its wide diffusion. It shorthands botany.

\section{The Geological History of Plants.}

By Sir J. William Dawson, F.R.S. Illustrated. I 2 mo. Cloth, \$1.75.

The object of this work is to give, in a connected form, a summary of the development of the vegetable kingdom in geological time. To the geologist and botanist the subject is one of importance with reference to their special pursuits, and one on which it has not been easy to find any convenient manual of information. It is hoped that its treatment in the present volume will also be found sufficiently simple and popular to be attractive to the general reader.

\section{Botany.}

A Concise Manual for Students of Medicine and Science. By Alexander Johnstone, F.G.S. I 2 mo. Cloth, \$1.75.

This work is an attempt to construct a useful text-book for learners who are, or who have been, members of a class in botany.

\section{Fungi: Their Nature and Uses.}

By M. C. Cooke. Fdited by the Rev. M. J. Berkeley. I 2 mo. Cloth, \$1.50.

\section{Handbook of Tree-Planting; or, Why to Plant, What to Plant, How to Plant.}

By Nathaniel H. Egleston, late Chief of Forestry Division, Department of Agriculture, Washington. I6mo. Cloth, 75 cents.

D. APPLETON AND COMPANY, NEW YORK. 


\section{POPULAR BOTANY.}

\section{The Folk-Lore of Plants.}

By T. F. Thiselton Dyer, M.A. I 2 mo. Cloth, $\$ 1.50$.

A useful handbook for those desirous of gaining some information, in a brief, concise form, of the folk-lore of the vegetable kingdom.

"A handsome and deeply interesting volume. . . . In all respects the book is excellent. Its arrangement is simple and intelligible, its style bright and alluring. . . To all who seek an introduction to one of the most attractive branches of folk-lore, this delightful volume may be warmly commended."-Notes and Queries.

\section{Flowers and Their Pedigrees.}

By Grant Allen. Illustrated. I 2mo. Cloth, \$I.5O.

These essays deal with the evolution of certain plant types in general, and the causes of their existence in restricted localities.

"No writer treats scientific subjects with so much ease and charm of style as Mr. Grant Allen. The study is a delightful one, and the book is fascinating to anyone who has either love for flowers or curiosity about them."-Hartford Courant.

"Anyone with even a smattering of botanical knowledge, and with either a heart or mind, must be charmed with this collection of essays." - Chicago Evening Journal.

\section{The Story of the Plants.}

By Grant Allen. With Many Illustrations. I6mo. Cloth, 35 cents net; postage, 4 cents additional.

A short and succinct account of the principal phenomena of plant life, in language suited to the comprehension of unscientific readers.

D. APPLETON AND COMPANY, NEW YORK. 





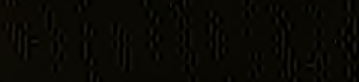

